\title{
WestVirginiaUniversity
}

THE RESEARCH REPOSITORY @ WVU

Graduate Theses, Dissertations, and Problem Reports

2017

\section{The Impact of Shale Gas on Gas Storage Performance}

Arya Maher Sattari

Follow this and additional works at: https://researchrepository.wvu.edu/etd

\section{Recommended Citation}

Sattari, Arya Maher, "The Impact of Shale Gas on Gas Storage Performance" (2017). Graduate Theses, Dissertations, and Problem Reports. 6571.

https://researchrepository.wvu.edu/etd/6571

This Thesis is protected by copyright and/or related rights. It has been brought to you by the The Research Repository @ WVU with permission from the rights-holder(s). You are free to use this Thesis in any way that is permitted by the copyright and related rights legislation that applies to your use. For other uses you must obtain permission from the rights-holder(s) directly, unless additional rights are indicated by a Creative Commons license in the record and/ or on the work itself. This Thesis has been accepted for inclusion in WVU Graduate Theses, Dissertations, and Problem Reports collection by an authorized administrator of The Research Repository @ WVU. For more information, please contact researchrepository@mail.wvu.edu. 
THE IMPACT OF SHALE GAS ON GAS STORAGE PERFORMANCE

Arya Maher Sattari

Thesis Submitted

to the Benjamin M. Statler College of Engineering and Mineral Resources

Department of Petroleum and Natural Gas Engineering

at West Virginia University

in partial fulfillment of the requirements for the degree of

Master of Science in

Petroleum and Natural Gas Engineering

Samuel Ameri, M.S., Chair

Kashy Aminian, Ph.D.

Mehrdad Zamirian, Ph.D.

Department of Petroleum and Natural Gas Engineering

Morgantown, West Virginia

2017

Keywords: Gas Storage, Storage Performance, Shale Gas, Storage Pressure Copyright 2017 Arya Maher Sattari 


\section{ABSTRACT \\ The Impact of Shale Gas on Gas Storage Performance \\ Arya Sattari}

The advances in technology has resulted in significant gas production from the shale formations across the United States. Marcellus Shale which spans most of the Appalachian Basin is one the most prolific gas producers in the United States. Marcellus Shale gas has a distinctly different composition from the existing Northern Appalachian typical dry natural gas. As gas production from Marcellus shale has increased, so has the amount of the shale gas in the natural gas transportation system in the Appalachian Basin. The composition of the injected gas into a storage reservoir can the storage volumes, pressures, the withdrawal rate, and the pressure drawdown.

The objective of this study is to investigate the impact of storing Marcellus Shale gas on the capacity and deliverability of a gas storage reservoir. In this study, the working gas in the storage was assumed to be a mixture of the Marcellus Shale gas and the original pipeline (storage) gas. The fraction of the shale gas in the mixture was varied from 10 percent to 50 percent to determine the changes in the storage working volume, storage top pressure, withdrawal rate, and pressure drawdown. The results indicate that there is linear relationship between the fraction of the shale gas in the working gas and the changes in mixture storage working volume, storage top pressure, withdrawal rate, and pressure drawdown. 


\section{Acknowledgement}

I would like to take this opportunity to thank Professor Samuel Ameri and Dr. Kashy Aminian for their unwavering support and encouragement throughout my time spent as a student and graduate assistant in the Petroleum and Natural Gas Engineering department at West Virginia University’s Benjamin M. Statler College of Engineering and Mineral Resources. Their advice and guidance has been invaluable throughout the course of my time in the program, and I do not believe I'd have accomplished what I have without their assistance. Professor Samuel Ameri was always available to help in every area of the program and as my research advisor. Between Professor Ameri and Dr. Kashy Aminian, the two went above and beyond with their advice and assistance throughout my research and thesis, as well as providing opportunities for industry experience, and post graduate careers. I would also like to thank Dr. Mehrdad Zamirian, with whom I had the pleasure of assisting as a graduate assistant through a number of his courses. And lastly, I would also like to thank the rest of the teaching staff at West Virginia University’s Petroleum Engineering department, as well as our department administrative assistant Mrs. Beverly Matheny, for all of the help and knowledge shared throughout the years. 


\section{Table of Contents}

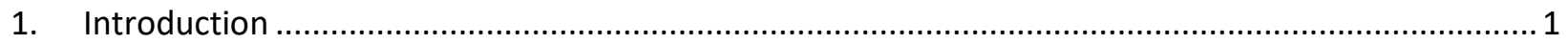

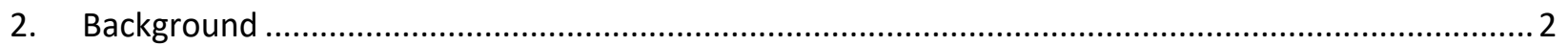

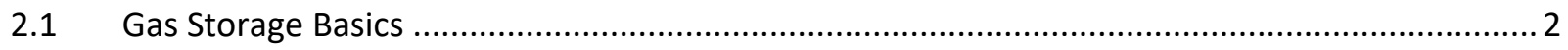

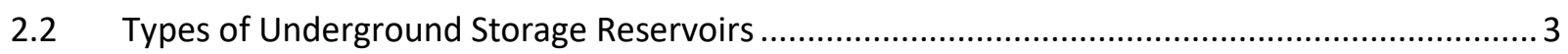

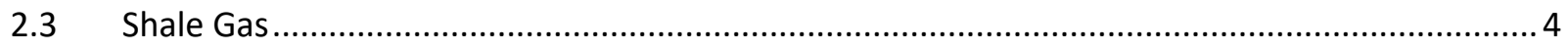

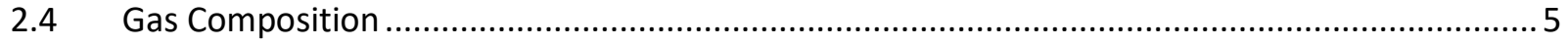

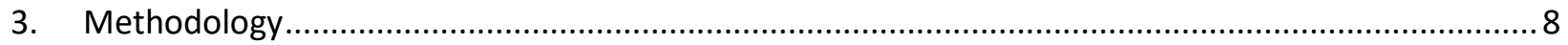

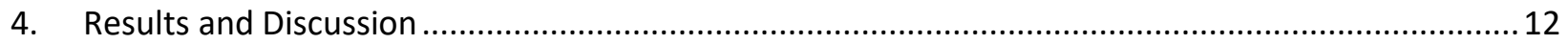

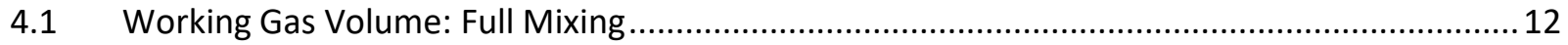

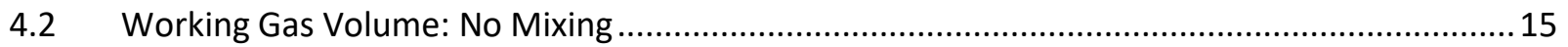

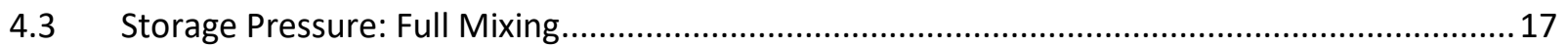

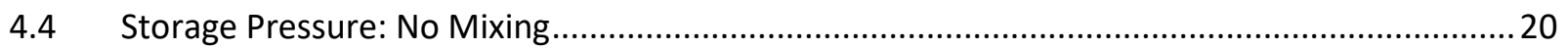

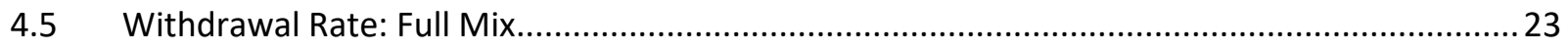

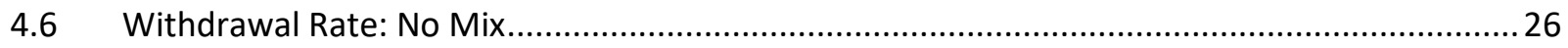

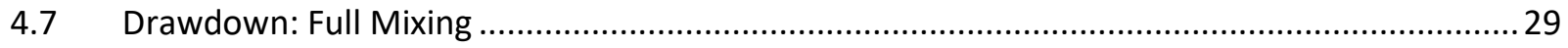

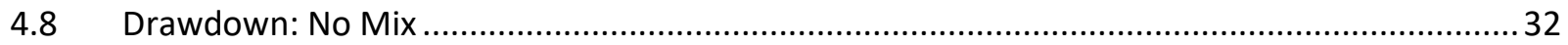

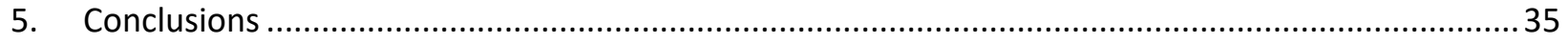

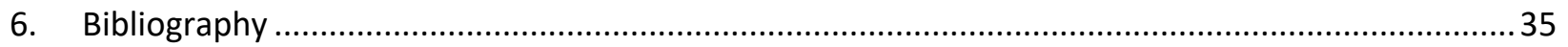

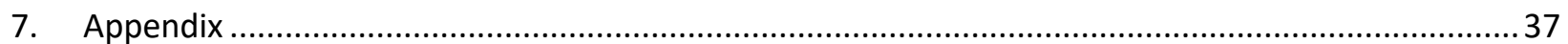

Appendix A - Shale Gas and Storage Gas Compositions and properties............................................37

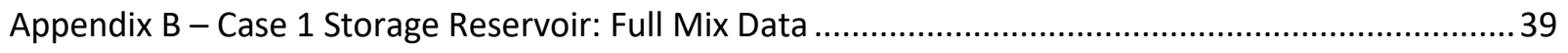

Appendix C - Case 2 Storage Reservoir: Full Mix Data ...................................................................... 44

Appendix D - Case 3 Storage Reservoir: Full Mix Data.................................................................... 49

Appendix E - Storage Reservoir: No Mix Data (Cases 1, 2, \& 3) ...................................................... 54

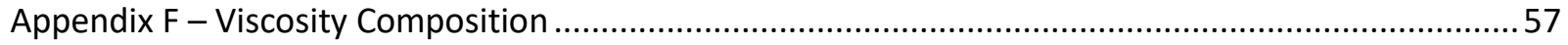

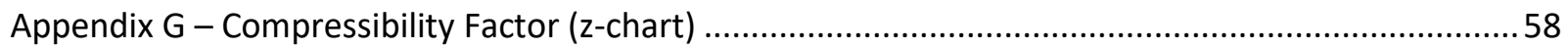

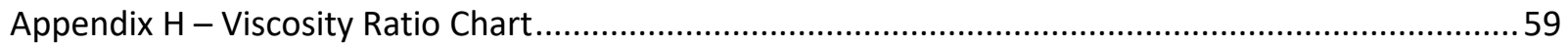




\section{List of Tables}

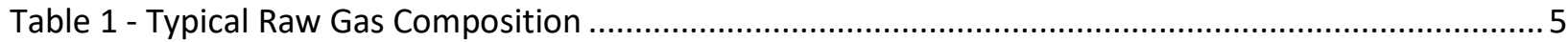

Table 2 - Typical U.S. Tariff Limits (Stokes \& Summers, 2012) .......................................................... 6

Table 3 - Marcellus Shale Gas Composition (Bullin \& Krouskop, 2008) .................................................. 7

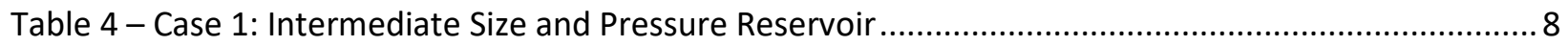

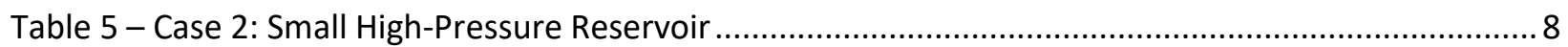

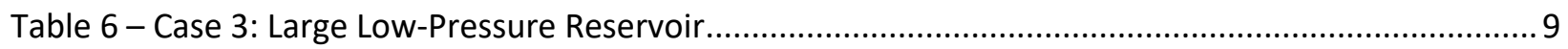

Table 7 - Typical Gas Composition for Gas Storage Reservoir .......................................................... 9

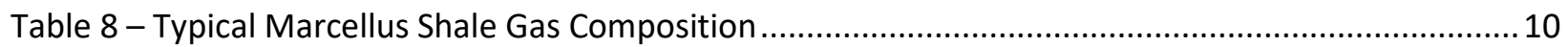

Table 9 - Case 1: Full Mix - Volume \% Change - Intermediate Size and Pressure Reservoir .....................12

Table 10 - Case 2: Full Mix - Volume \% Change - Small High-Pressure Reservoir .................................... 12

Table 11 - Case 3: Full Mix - Volume \% Change - Large Low-Pressure Reservoir ...................................... 13

Table 12 - Case 1: No Mixing - Volume \% Change - Intermediate Size and Pressure Reservoir................. 15

Table 13 - Case 2: No Mixing - Volume \% Change - Small High-Pressure Reservoir ................................ 15

Table 14 - Case 3: No Mixing - Volume \% Change - Large Low-Pressure Reservoir................................... 15

Table 15 - Case 1: Full Mix - Pressure \% Change - Intermediate Size and Pressure Reservoir.................. 17

Table 16 - Case 2: Full Mix - Pressure \% Change - Small High-Pressure Reservoir.................................. 18

Table 17 - Case 3: Full Mix - Pressure \% Change - Large Low-Pressure Reservoir ................................... 18

Table 18 - Case 1: No Mixing - Pressure \% Change - Intermediate Size and Pressure Reservoir...............20

Table 19 - Case 2: No Mixing - Pressure \% Change - Small High-Pressure Reservoir................................21

Table 20 - Case 3: No Mixing - Pressure \% Change - Large Low-Pressure Reservoir ................................21

Table 21 - Case 1: Full Mix - Withdrawal Rate \% Change - Intermediate Size and Pressure Reservoir ....23

Table 22 - Case 2: Full Mix - Withdrawal Rate \% Change - Small High-Pressure Reservoir ...................... 24

Table 23 - Case 3: Full Mix - Withdrawal Rate \% Change - Large Low-Pressure Reservoir ........................ 24

Table 24 - Case 1: No Mixing - Withdrawal Rate \% Change - Intermediate Size and Pressure Reservoir. 26

Table 25 - Case 2: No Mixing - Withdrawal Rate \% Change - Small High-Pressure Reservoir................... 27

Table 26 - Case 3: No Mixing - Withdrawal Rate \% Change - Large Low-Pressure Reservoir ....................27

Table 27- Case 1: Full Mix - Drawdown \% Change - Intermediate Size and Pressure Reservoir ...............29

Table 28- Case 2: Full Mix - Drawdown \% Change - Small High-Pressure Reservoir..................................30

Table 29 - Case 3: Full Mix - Drawdown \% Change - Large Low-Pressure Reservoir................................ 30

Table 30 - Case 1: No Mixing - Drawdown \% Change - Intermediate Size and Pressure Reservoir ........... 32

Table 31 - Case 2: No Mixing - Drawdown \% Change - Small High-Pressure Reservoir ............................ 32

Table 32 - Case 3: No Mixing - Drawdown \% Change - Large Low-Pressure Reservoir............................ 32

Table 33 - Typical Marcellus Shale Gas (Working Gas) Composition........................................................ 37

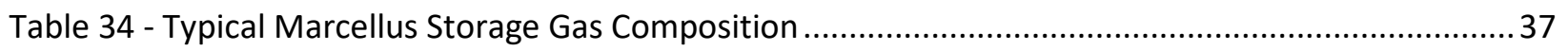

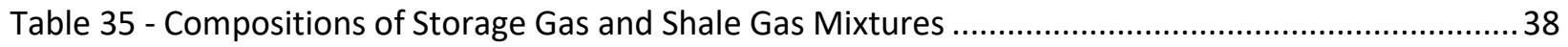

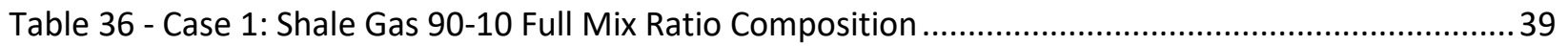

Table 37 - Case 1 Storage Reservoir: 90-10 Full Mix Composition .......................................................... 39

Table 38 - Case 1: Shale Gas 80-20 Full Mix Ratio Composition ..............................................................40

Table 39 - Case 1 Storage Reservoir: 80-20 Full Mix Composition ....................................................... 40

Table 40 - Case 1: Shale Gas 70-30 Full Mix Ratio Composition ............................................................ 41

Table 41 - Case 1 Storage Reservoir: 70-30 Full Mix Composition ...................................................... 41

Table 42 - Case 1: Shale Gas 60-40 Full Mix Ratio Composition .............................................................42

Table 43 - Case 1 Storage Reservoir: 60-40 Full Mix Composition ..........................................................42 
Table 44 - Case 1: Shale Gas 50-50 Full Mix Ratio Composition ............................................................ 43

Table 45 - Case 1 Storage Reservoir: 50-50 Full Mix Composition ............................................................ 43

Table 46 - Case 2: Shale Gas 90-10 Full Mix Ratio Composition ............................................................. 44

Table 47 - Case 2 Storage Reservoir: 90-10 Full Mix Composition ....................................................... 44

Table 48 - Case 2: Shale Gas 80-20 Full Mix Ratio Composition ............................................................ 45

Table 49 - Case 2 Storage Reservoir: 80-20 Full Mix Composition ......................................................... 45

Table 50 - Case 2: Shale Gas 70-30 Full Mix Ratio Composition ............................................................46

Table 51 - Case 2 Storage Reservoir: 70-30 Full Mix Composition .......................................................46

Table 52 - Case 2: Shale Gas 60-40 Full Mix Ratio Composition ........................................................... 47

Table 53 - Case 2 Storage Reservoir: 60-40 Full Mix Composition ......................................................... 47

Table 54 - Case 2: Shale Gas 50-50 Full Mix Ratio Composition ............................................................. 48

Table 55 - Case 2 Storage Reservoir: 50-50 Full Mix Composition ....................................................... 48

Table 56 - Case 3: Shale Gas 90-10 Full Mix Ratio Composition ............................................................. 49

Table 57 - Case 3 Storage Reservoir: 90-10 Full Mix Composition ......................................................... 49

Table 58 - Case 3: Shale Gas 80-20 Full Mix Ratio Composition ..............................................................50

Table 59 - Case 3 Storage Reservoir: 80-20 Full Mix Composition .......................................................50

Table 60 - Case 3: Shale Gas 70-30 Full Mix Ratio Composition ............................................................. 51

Table 61 - Case 3 Storage Reservoir: 70-30 Full Mix Composition ........................................................5 51

Table 62 - Case 3: Shale Gas 60-40 Full Mix Ratio Composition ........................................................... 52

Table 63 - Case 3 Storage Reservoir: 60-40 Full Mix Composition ........................................................52

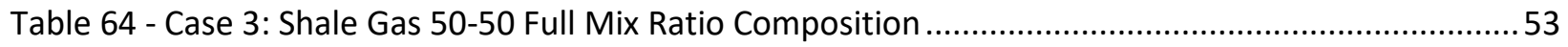

Table 65 - Case 3 Storage Reservoir: 50-50 Full Mix Composition ........................................................53

Table 66 - Case 1 Storage Reservoir: 90-10 No Mix Composition ..........................................................5

Table 67 - Case 1 Storage Reservoir: 80-20 No Mix Composition ..........................................................5

Table 68 - Case 1 Storage Reservoir: 70-30 No Mix Composition ........................................................5 55

Table 69 - Case 1 Storage Reservoir: 60-40 No Mix Composition .........................................................5 55

Table 70 - Case 1 Storage Reservoir: 50-50 No Mix Composition ..........................................................5 56

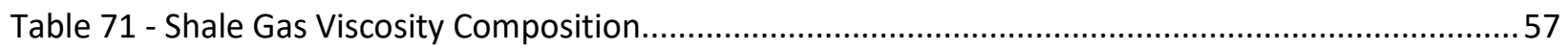

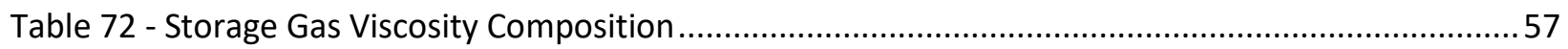




\section{List of Figures}

Figure 1 - Shale Basins in Lower 48 States (Stokes \& Summers, 2012) ................................................. 5

Figure 2 - Case 1: Full Mix - Volume \% Change - Intermediate Size and Pressure Reservoir................... 13

Figure 3 - Case 2: Full Mix - Volume \% Change - Small High-Pressure Reservoir ..................................... 14

Figure 4 - Case 3: Full Mix - Volume \% Change - Large Low-Pressure Reservoir...................................... 14

Figure 5 - Case 1: No Mixing - Volume \% Change - Intermediate Size and Pressure Reservoir ..................16

Figure 6 - Case 2: No Mixing - Volume \% Change - Small High-Pressure Reservoir .................................. 16

Figure 7 - Case 3: No Mixing - Volume \% Change - Large Low-Pressure Reservoir...................................17

Figure 8 - Case 1: Full Mix - Pressure \% Change - Intermediate Size and Pressure Reservoir ................... 19

Figure 9 - Case 2: Full Mix - Pressure \% Change - Small High-Pressure Reservoir .................................. 19

Figure 10 - Case 3: Full Mix - Pressure \% Change - Large Low-Pressure Reservoir ................................... 20

Figure 11 - Case 1: No Mixing - Pressure \% Change - Intermediate Size and Pressure Reservoir ............. 22

Figure 12 - Case 2: No Mixing - Pressure \% Change - Small High-Pressure Reservoir ............................22

Figure 13 - Case 3: No Mixing - Pressure \% Change - Large Low-Pressure Reservoir ...............................23

Figure 14 - Case 1: Full Mix - Withdrawal Rate \% Change - Intermediate Size and Pressure Reservoir ... 25

Figure 15 - Case 2: Full Mix - Withdrawal Rate \% Change - Small High-Pressure Reservoir .....................25

Figure 16 - Case 3: Full Mix - Withdrawal Rate \% Change - Large Low-Pressure Reservoir......................26

Figure 17 - Case 1: No Mixing - Withdrawal Rate \% Change - Intermediate Size and Pressure Reservoir28

Figure 18 - Case 2: No Mixing - Withdrawal Rate \% Change - Small High-Pressure Reservoir ................ 28

Figure 19 - Case 3: No Mixing - Withdrawal Rate \% Change - Large Low-Pressure Reservoir ..................29

Figure 20 - Case 1: Full Mix - Drawdown \% Change - Intermediate Size and Pressure Reservoir............. 30

Figure 21 - Case 2: Full Mix - Drawdown \% Change - Small High-Pressure Reservoir ............................. 31

Figure 22 - Case 3: Full Mix - Drawdown \% Change - Large Low-Pressure Reservoir .............................. 31

Figure 23 - Case 1: No Mixing - Drawdown \% Change - Intermediate Size and Pressure Reservoir......... 33

Figure 24 - Case 2: No Mixing - Drawdown \% Change - Small High-Pressure Reservoir ............................33

Figure 25 - Case 3: No Mixing - Drawdown \% Change - Large Low-Pressure Reservoir............................ 34

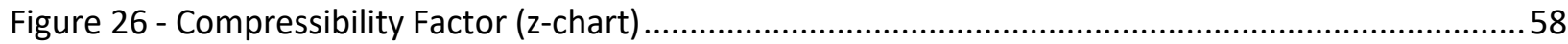

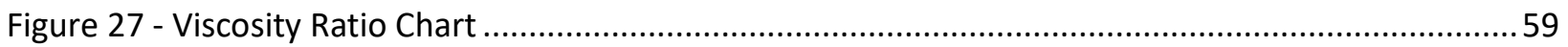




\section{Introduction}

The advances in hydraulic fracturing and horizontal well technology have unlocked considerable natural gas reserves contained in the shale formations. Marcellus Shale, a Devonian black shale, spans the majority of the Appalachian Basin from New York through Pennsylvania, West Virginia and also extends into Ohio and Maryland. Marcellus Shale is prolific in size and is located strategically in regards to markets in the Northeastern areas, Eastern Seaboard, and Great Lakes region of the United States. Marcellus Shale in recent years has become the most prolific gas producer in the United States. Marcellus Shale gas has a distinctly different composition than the existing Northern Appalachian typical dry natural gas. Due to lack of processing or blending capabilities, the gas produced from the Marcellus shale wells are transported with pipeline and are mixed with the pipeline gas.

Due to seasonal nature of the gas demand, natural is often stored in underground storage facilities during low demand period and then is withdrawn during the high demand periods. The composition of the injected gas in the storage reservoir can impact the gas compressibility and as a consequence the storage volumes or pressures. Furthermore, the composition of gas influences the viscosity of the gas and therefore the withdrawal rate or the pressure drawdown in the storage reservoir. It is therefore important to investigate the impact of the storing a mixture of shale and pipeline gas in the storage reservoir in the Appalachian basin. 


\section{Background}

\subsection{Gas Storage Basics}

Natural gas is typically a seasonal fuel, where demand is higher during the winter than it is during warmer months. Due to this, it is necessary to store the gas in times where demand is less, increasing the "base load" in order to meet the supply during short term "Peak Load" demand increases. This is done in various ways; the gas can be stored in underground facilities such as depleted gas reservoirs, aquifers, and salt caverns or stored as liquefied natural gas (LNG) where the natural gas takes up less space and allows for the natural gas to be shipped and stored in liquid form.

As well as meeting base load and peak load demand, gas storage is also used as insurance against disruptions in supply or production. The natural gas is injected into the formation, building pressure and thus becoming a pressurized natural gas container. This pressure is necessary as the higher it is, the more readily available the gas may be extracted. This pressure must remain above that of the wellhead or else there will not be a large enough pressure differential to push the natural gas out of the storage facility. This is referred to as "Base Gas" or "Cushion gas" and must remain in the storage reservoir to maintain the required pressure to extract the remaining gas.

The volume of natural gas in the storage reservoir that can be extracted is called "Working Gas." Working Gas is the gas being stored and withdrawn during normal operations. As this volume is decreased, pressure and deliverability also decrease. This then asks the question of what happens when or if the working gas mixes with the base gas.

Natural gas storage is necessary to maintain a reliable supply of gas to meet the demands of the consumers. Underground storage is an efficient process that can keep up the constant supply from long-distance pipelines with the variable market demand. During warmer months, when the pipeline capacity is greater than the market demand, the natural gas can be placed into underground storage and then during periods of higher supply, typically colder winter months, the gas can be withdrawn and used (Aminian, 2015).

Storage is also used in the industry for commercial reasons to efficiently earn based on the market where factors such as regulations and political climate can dictate the gas price. Storing gas during 
times when the price is low and withdrawing to sell when prices are high allows for effective economics (NatGas, 2014).

\subsection{Types of Underground Storage Reservoirs}

There are three main types of underground natural gas storage: depleted reservoirs, aquifers, and salt caverns.

Depleted gas reservoirs are the most common, cheapest, and prominent types of underground storage. These are formations that have already been extracted of all of their recoverable natural gas, and are desirable as they are already proven geologically capable of holding natural gas. Often times the developed reservoir already has the infrastructure for extraction and distribution left over from while the field was in production and can reduce costs when converting to storage purposes. This makes depleted gas reservoirs one of the cheapest storage types to develop, operate and maintain (NatGas, 2014).

Aquifer storage is when natural gas is injected into underground porous, permeable rock formations that act as natural water reservoirs. These formations can be reconditioned and used as natural gas storage facilities, where the gas is injected at the top of the formation and displaces the water down structure (Dietert \& Pursell, 2000).

Typically, aquifer storage is used only in areas without any depleted reservoirs, as they are more expensive to develop than depleted reservoirs. This is usually close to the end market user, and only accounts for $10 \%-15 \%$ of total US storage. Another disadvantage with aquifer storage is that their geological characteristics are not as thoroughly understood as those of a depleted reservoir. In order to develop the aquifer into an effective natural gas storage facility, tests must be done to determine the suitability, composition, capacity, and porosity of the formation. These tests add to the cost and time needed to get the aquifer reservoir ready for storage. Additionally, since gas does not naturally occur in the formation, a certain amount of base gas must be added. This base gas requirement can be as high as $80 \%$ of the total gas volume, and is often times not recoverable at risk of damaging the formation. These factors mean that the development of storage reservoir from an aquifer formation is both costly and lengthy, in some cases taking up to twice the time of that for a depleted reservoir (NatGas, 2014). 
Underground salt formations offer another type of natural gas storage. Formed out of existing salt deposits, these formations are well suited to natural gas storage in that they allow little injected natural gas to escape from the formation unless specifically extracted. The walls of a salt cavern also have the structural strength of steel, making them very resilient to reservoir degradation over time.

Once a suitable salt formation is discovered and suitable for storage it is necessary to develop a "salt cavern" within the formation. Basically this consists of using water to dissolve and extract a certain amount of salt from the deposit resulting in a large empty space in the formation. This is done by drilling a well into the salt formation and cycling large amounts of water through the completed well. Known as 'salt cavern leaching' this water dissolves some of the salt in the deposit and, cycled back up the well, leaves a large empty space where some of the salt once was. Salt cavern leaching can be very expensive, but the resulting salt cavern offers an underground gas storage vessel with very high deliverability. In addition, cushion gas requirements are the lowest of all three storage types, with salt caverns only requiring about 33\% of total capacity to be used as cushion gas and are best suited for peak load storage.

\subsection{Shale Gas}

Shale, an organic rich formation, is the source rock as well as the reservoir for a vast majority of the natural gas hydrocarbon production found in the United States. As seen in Figure 1 below, there are shale gas reservoirs covering the north and south regions of the United States including New York, Pennsylvania, West Virginia, Ohio, Wyoming, Colorado, Illinois, Texas, Oklahoma, and New Mexico. The gas is stored in the limited pore space of these formations, as shale is a complicated naturally fractured reservoir. With ultra-low matrix permeability values in the nanodarcy range, unconventional shale reservoirs are not believed to produce economically unless an interconnected fracture system is developed (Garcia-Hernandez, Alvarado, \& Ridens, 2015). This is typically achieved through effective placement of horizontal laterals and hydraulic stimulation treatment. The objective of the horizontal wells and stimulation treatment is to create a large, highly fractured, interconnected network allowing for contact to be made with as much of the formation surface as possible and providing access to the hydrocarbons (Elsaig, Aminian, Ameri, \& Zamirian, 2016). 


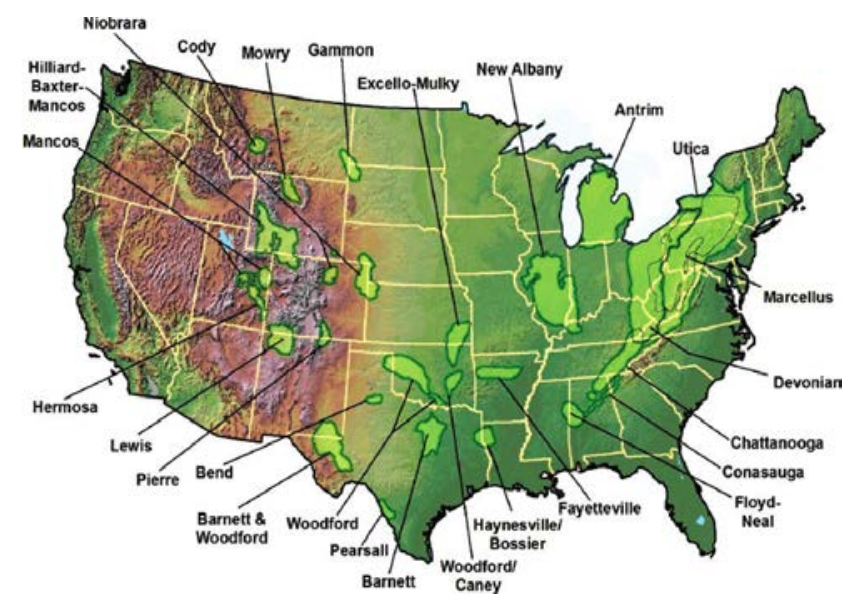

Figure 1 - Shale Basins in Lower 48 States (Stokes \& Summers, 2012)

Spanning the majority of the Appalachian Basin, the Marcellus Shale, a Devonian black shale formation extends from New York through Pennsylvania, West Virginia, Ohio and Maryland (Ayers, Aminian, \& Ameri, 2012). The Marcellus has tremendous potential, and is relatively shallow at depths of 2,000-8,000 ft. and 300-1,000 ft. thick, seen in Figure 2. Initial production rates show production in the 0.5-4 MMSCFD range, with estimates of 60-100 SCF of gas per ton of shale (Bullin \& Krouskop, 2008).

\subsection{Gas Composition}

Table 1 illustrates typical gas compositions from different sources. As can be seen, Methane is always the major component, typically comprising $60 \%$ to $98 \%$ of the total.

Table 1 - Typical Raw Gas Composition

\begin{tabular}{|l|c|c|c|}
\hline Gas Component & $\begin{array}{c}\text { Casinghead (Wet) Gas } \\
(\mathrm{mol} \%)\end{array}$ & $\begin{array}{c}\text { Gas Well (Dry) Gas } \\
(\mathrm{mol} \%)\end{array}$ & $\begin{array}{c}\text { Condensate Well Gas } \\
\text { (mol \%) }\end{array}$ \\
\hline Carbon Dioxide & 0.63 & Trace & Trace \\
\hline Nitrogen & 3.73 & 1.25 & 0.53 \\
\hline Hydrogen Sulfide & 0.57 & Trace & Trace \\
\hline Methane & 64.48 & 91.01 & 2.89 \\
\hline Ethane & 11.98 & 4.88 & 0.92 \\
\hline Propane & 8.75 & 1.69 & 0.31 \\
\hline Iso-Butane & 0.93 & 0.14 & 0.22 \\
\hline n-Butane & 2.91 & 0.52 & 0.09 \\
\hline Iso-Pentane & 0.54 & 0.09 & 0.06 \\
\hline n-Pentane & 0.80 & 0.18 & 0.05 \\
\hline Hexanes & 0.37 & 0.13 & 0.06 \\
\hline Heptanes plus & 0.31 & 0.11 & 100.00 \\
\hline Total & 100.00 & 100.00 & \\
\hline
\end{tabular}


Additionally, natural gas contains significant amounts of ethane, some propane and butane, and typically $1 \%$ to $3 \%$ of other heavier hydrocarbons. Often, natural gas contains associated and undesirable impurities, such as water, carbon dioxide, nitrogen, and hydrogen sulfide. Although the composition of raw gas varies widely, the composition of gas delivered to commercial pipeline grids is tightly controlled.

In order for the gas producers to meet pipeline specifications, all natural gas requires some treatment even if all that is done is to remove bulk water. Around a fifth of gas extracted requires extensive, and often expensive, treatment, before it can be delivered to the pipeline. Processing of natural gas is therefore, by some considerable margin, the largest industrial gas application. In the U.S., production of natural gas is presently around 22 trillion SCF/Year and expected to increase to more than 31 trillion SCF/Year by 2025. It follows that U.S. production accounts for somewhere in the region of $20 \%$ of total Global production making the U.S. a key market both for gas producers, processing equipment, and instrumentation suppliers (Bullin \& Krouskop, 2008).

Table 2 - Typical U.S. Tariff Limits (Stokes \& Summers, 2012)

\begin{tabular}{|l|c|c|}
\hline Component (molar \%) & Minimum & Maximum \\
\hline Methane & 75 & - \\
\hline Ethane & - & 18 \\
\hline Propane & - & 5 \\
\hline Butane & - & 2 \\
\hline Pentane Plus & - & 0.5 \\
\hline Nitrogen and other Inert & - & $3-4$ \\
\hline Carbon Dioxide & - & $3-4$ \\
\hline Trace Components & - & $0.25-1$ \\
\hline
\end{tabular}

As most existing Northern Appalachian gas is dry, it does not require removal of Natural Gas Liquids (NGL's) for pipe line transportation. However, the Marcellus gas has sufficient liquids that do require processing. With little CO2 and Nitrogen, the greatest obstacle the Marcellus faces is environmental challenges associated with the terrain of the area. From a gas processing point of view, the Marcellus region does not have the infrastructure as others do to deal with gas blending (Bullin \& Krouskop, 2008).

All shale gas is not the same, and composition varies substantially between formation and location. Table 5 shows the gas composition from several Marcellus shale Wells. As it can be observed, 
Marcellus Shale gas has distinctly different composition than typical natural gas. The key difference is the mole fraction of Ethane, seen in Table 3 Column C2.

Table 3 - Marcellus Shale Gas Composition (Bullin \& Krouskop, 2008)

\begin{tabular}{|c|c|c|c|c|c|}
\hline \multicolumn{7}{|c|}{ Marcellus Shale Gas Composition } \\
\hline Well & C1 & C2 & C3 & CO2 & N2 \\
\hline 1 & 79.4 & 16.1 & 4.0 & 0.1 & 0.4 \\
\hline 2 & 82.1 & 14.0 & 3.5 & 0.1 & 0.3 \\
\hline 3 & 83.8 & 12.0 & 3.0 & 0.9 & 0.3 \\
\hline 4 & 95.5 & 3.0 & 1.0 & 0.3 & 0.2 \\
\hline
\end{tabular}

With rapid production growth, shale gas processing requires composition to be determined in order to deal with concerns such as elevated ethane and nitrogen levels across fields.

Some anticipate that the Marcellus shale reserves could hold twice as much gas as the Texas Barnett Shale. If true, gas processing would create substantial volumes of natural gas liquids for the region. 


\section{Methodology}

The objective of this study is to investigate the impact of storing Marcellus Shale gas on the capacity and deliverability of a gas storage reservoir. For the purpose of this study the following steps were developed and implement:

1. Three generic storage reservoirs were considered in this study which represent typical characteristics of different gas storage reservoirs in the Appalachian Basin. The characteristics of these storage reservoir are summarized in Tables 4, 5, and 6 and include an intermediate size and pressure reservoir (Case 1), a small high pressure reservoir (Case 2), and a large low pressure reservoir (Case 3).

Table 4-Case 1: Intermediate Size and Pressure Reservoir

\begin{tabular}{|l|c|l|}
\hline \multicolumn{3}{|c|}{ Case 1 } \\
\hline Working Gas Volume & 55 & BCF \\
\hline Base Gas Volume & 45 & BCF \\
\hline Maximum Pressure & 2250.0 & psia \\
\hline Reservoir Temperature & 100 & ${ }^{\circ} \mathrm{F}$ \\
\hline Net Pay & 15 & $\mathrm{ft}$. \\
\hline Permeability & 150 & $\mathrm{md}$ \\
\hline Water Saturation & 0.25 & \\
\hline Effective Porosity & 12 & $\%$ \\
\hline Average Depth & 4688 & $\mathrm{ft}$. \\
\hline
\end{tabular}

Table 5 - Case 2: Small High-Pressure Reservoir

\begin{tabular}{|l|c|l|}
\hline \multicolumn{3}{|c|}{ Case 2 } \\
\hline Working Gas Volume & 4 & BCF \\
\hline Base Gas Volume & 4 & BCF \\
\hline Maximum Pressure & 2700.0 & psia \\
\hline Reservoir Temperature & 120 & ${ }^{\circ} \mathrm{F}$ \\
\hline Net Pay & 50 & $\mathrm{ft}$. \\
\hline Permeability & 100 & $\mathrm{md}$ \\
\hline Water Saturation & 0.2 & \\
\hline Effective Porosity & 10 & $\%$ \\
\hline Average Depth & 5625 & $\mathrm{ft}$. \\
\hline
\end{tabular}


Table 6-Case 3: Large Low-Pressure Reservoir

\begin{tabular}{|l|c|l|}
\hline \multicolumn{3}{|c|}{ Case 3 } \\
\hline Working Gas Volume & 85 & BCF \\
\hline Base Gas Volume & 75 & BCF \\
\hline Maximum Pressure & 1100.0 & psia \\
\hline Reservoir Temperature & 80 & o F \\
\hline Net Pay & 15 & ft. \\
\hline Permeability & 120 & md \\
\hline Water Saturation & 0.25 & \\
\hline Effective Porosity & 12 & $\%$ \\
\hline Average Depth & 2292 & $\mathrm{ft}$. \\
\hline
\end{tabular}

2. A typical gas composition from gas storage reservoirs in West Virginia was utilized as the base gas composition for all of the cases. This gas composition is provided in Table 7.

Table 7 - Typical Gas Composition for Gas Storage Reservoir

\begin{tabular}{|c|c|}
\hline \multicolumn{1}{c|}{} & Storage \\
\hline Component & Mole Fraction \\
\hline $\mathrm{CO}_{2}$ & 0.001 \\
\hline $\mathrm{N}_{2}$ & 0.002 \\
\hline $\mathrm{H}_{2} \mathrm{~S}$ & 0.000 \\
\hline $\mathrm{CH}_{4}$ & 0.980 \\
\hline $\mathrm{C}_{2} \mathrm{H}_{6}$ & 0.010 \\
\hline $\mathrm{C}_{3} \mathrm{H}_{8}$ & 0.003 \\
\hline$i-\mathrm{C}_{4} \mathrm{H}_{10}$ & 0.002 \\
\hline$n-\mathrm{C}_{4} \mathrm{H}_{10}$ & 0.0008 \\
\hline$i-\mathrm{C}_{5} \mathrm{H}_{12}$ & 0.0004 \\
\hline$n-\mathrm{C}_{5} \mathrm{H}_{12}$ & 0.0003 \\
\hline $\mathrm{C}_{6} \mathrm{H}_{14}$ & 0.0002 \\
\hline $\mathrm{C}_{7}+$ & 0.0003 \\
\hline Total & 1.0000 \\
\hline
\end{tabular}


3. A typical Marcellus shale gas composition in West Virginia was utilized for the composition of the injected Marcellus Shale gas for all of the cases. This gas composition is provided in Table 8.

\section{Table 8 - Typical Marcellus Shale Gas Composition}

\begin{tabular}{|c|c|}
\cline { 2 - 2 } & Shale \\
\hline Component & Mole Fraction \\
\hline $\mathrm{CO}_{2}$ & 0.001 \\
\hline $\mathrm{N}_{2}$ & 0.003 \\
\hline $\mathrm{H}_{2} \mathrm{~S}$ & 0.000 \\
\hline $\mathrm{CH}_{4}$ & 0.760 \\
\hline $\mathrm{C}_{2} \mathrm{H}_{6}$ & 0.150 \\
\hline $\mathrm{C}_{3} \mathrm{H}_{8}$ & 0.059 \\
\hline$i-\mathrm{C}_{4} \mathrm{H}_{10}$ & 0.007 \\
\hline$n-\mathrm{C}_{4} \mathrm{H}_{10}$ & 0.007 \\
\hline$i-\mathrm{C}_{5} \mathrm{H}_{12}$ & 0.004 \\
\hline$n-\mathrm{C}_{5} \mathrm{H}_{12}$ & 0.003 \\
\hline $\mathrm{C}_{6} \mathrm{H}_{14}$ & 0.002 \\
\hline $\mathrm{C}_{7}+$ & 0.004 \\
\hline Total & 1.0000 \\
\hline
\end{tabular}

4. It was assumed that the entire working gas in the storage reservoir is replaced by a mixture of the Marcellus Shale gas and the original pipeline (storage) gas. The fraction of the shale gas in the mixture was varied from 10 percent to 50 percent.

5. The composition of the working gas after it is injected into the storage reservoir will depend on the level of mixing between the working gas and the base gas. To investigate the impact of the degree of mixing the following scenarios were considered:

a. No Mixing: This case assumes that no mixing occurs between the injected and the base gas. Two sets of gas properties based on the original base gas and Marcellus gas compositions were determined for further calculations. 
b. Full Mixing: This case assumes that the injected gas and the base gas are completely mixed. A single set of gas properties based on the mixture of the base gas and Marcellus shale gas in proportion to the base and working gas were determined for further calculations.

6. For each case described above, the working gas volume required to fill the pore volume of the storage reservoir, excluding the base gas pore volume, at the top storage pressure was determined. The percentage change in working gas volume as compared to the original working gas volume was then determined.

7. For each case described above, a gas volume the same as the original working gas volume was injected into the storage reservoir and the resulting top pressure was determined. The percentage change in top storage pressure compared to the original top storage pressure was then determined.

8. For each case described above, the gas withdrawal rate for a drawdown of $400 \mathrm{psi}$ at the top pressure was determined. The percentage change in withdrawal rate compared to the original withdrawal rate was then determined.

9. For each case described above, the drawdown required to achieve the original flow rate (determined based on 400 psi drawdown using the base gas composition) at the top pressure was determined. The percentage change in drawdown compared to the original drawdown (400 psi) was then determined. 


\section{Results and Discussion}

The following sections provide the results for working gas volume, top storage pressure, withdrawal rate, drawdown, and percentage changes for each one as compared to the original reservoir conditions and for 3 reservoir cases.

\subsection{Working Gas Volume: Full Mixing}

The working gas volume required to fill the pore volume of the storage reservoir, excluding the base gas pore volume, at the top storage pressure for storage reservoir cases 1, 2, and 3 are summarized in Tables 9, 10 and 11. In addition, the percentage change in working gas volume as compared to the original working gas volume are summarized in each table.

\section{Table 9-Case 1: Full Mix - Volume \% Change - Intermediate Size and Pressure Reservoir}

\begin{tabular}{|c|c|c|c|}
\hline \multicolumn{4}{|c|}{ Case 1: Full Mix - Volume \% Change } \\
\hline $\begin{array}{c}\text { Mix Ratio } \\
\text { (Base:Working) }\end{array}$ & $\begin{array}{c}\text { Initial Volume } \\
\text { (BCF) }\end{array}$ & $\begin{array}{c}\text { New Volume } \\
\text { (BCF) }\end{array}$ & \% Change \\
\hline $90-10$ & 100.00 & 100.66 & $0.66 \%$ \\
\hline $80-20$ & 100.00 & 101.32 & $1.32 \%$ \\
\hline $70-30$ & 100.00 & 102.00 & $2.00 \%$ \\
\hline $60-40$ & 100.00 & 102.70 & $2.70 \%$ \\
\hline $50-50$ & 100.00 & 103.40 & $3.40 \%$ \\
\hline
\end{tabular}

Table 10 - Case 2: Full Mix - Volume \% Change - Small High-Pressure Reservoir

\begin{tabular}{|c|c|c|c|}
\hline \multicolumn{5}{|c|}{ Case 2: Full Mix - Volume \% Change } \\
\hline $\begin{array}{c}\text { Mix Ratio } \\
\text { (Base:Working) }\end{array}$ & $\begin{array}{c}\text { Initial Volume } \\
\text { (BCF) }\end{array}$ & $\begin{array}{c}\text { New Volume } \\
\text { (BCF) }\end{array}$ & \% Change \\
\hline $90-10$ & 8.00 & 8.04 & $0.50 \%$ \\
\hline $80-20$ & 8.00 & 8.09 & $1.13 \%$ \\
\hline $70-30$ & 8.00 & 8.13 & $1.63 \%$ \\
\hline $60-40$ & 8.00 & 8.17 & $2.13 \%$ \\
\hline $50-50$ & 8.00 & 8.22 & $2.75 \%$ \\
\hline
\end{tabular}


Table 11 - Case 3: Full Mix - Volume \% Change - Large Low-Pressure Reservoir

\begin{tabular}{|c|c|c|c|}
\hline \multicolumn{4}{|c|}{ Case 3: Full Mix - Volume \% Change } \\
\hline $\begin{array}{c}\text { Mix Ratio } \\
\text { (Base:Working) }\end{array}$ & $\begin{array}{c}\text { Initial Volume } \\
\text { (BCF) }\end{array}$ & $\begin{array}{c}\text { New Volume } \\
\text { (BCF) }\end{array}$ & \% Change \\
\hline $90-10$ & 160.00 & 160.74 & $0.46 \%$ \\
\hline $80-20$ & 160.00 & 161.50 & $0.94 \%$ \\
\hline $70-30$ & 160.00 & 162.28 & $1.43 \%$ \\
\hline $60-40$ & 160.00 & 163.08 & $1.93 \%$ \\
\hline $50-50$ & 160.00 & 163.90 & $2.44 \%$ \\
\hline
\end{tabular}

For all following cases, as the ratio of shale gas to the original gas in the mixture (working gas) was increased, the volume required to fill the pore volume of the reservoir increased. The percent change increased linearly for every case as illustrated in Figures 2, 3, and 4.

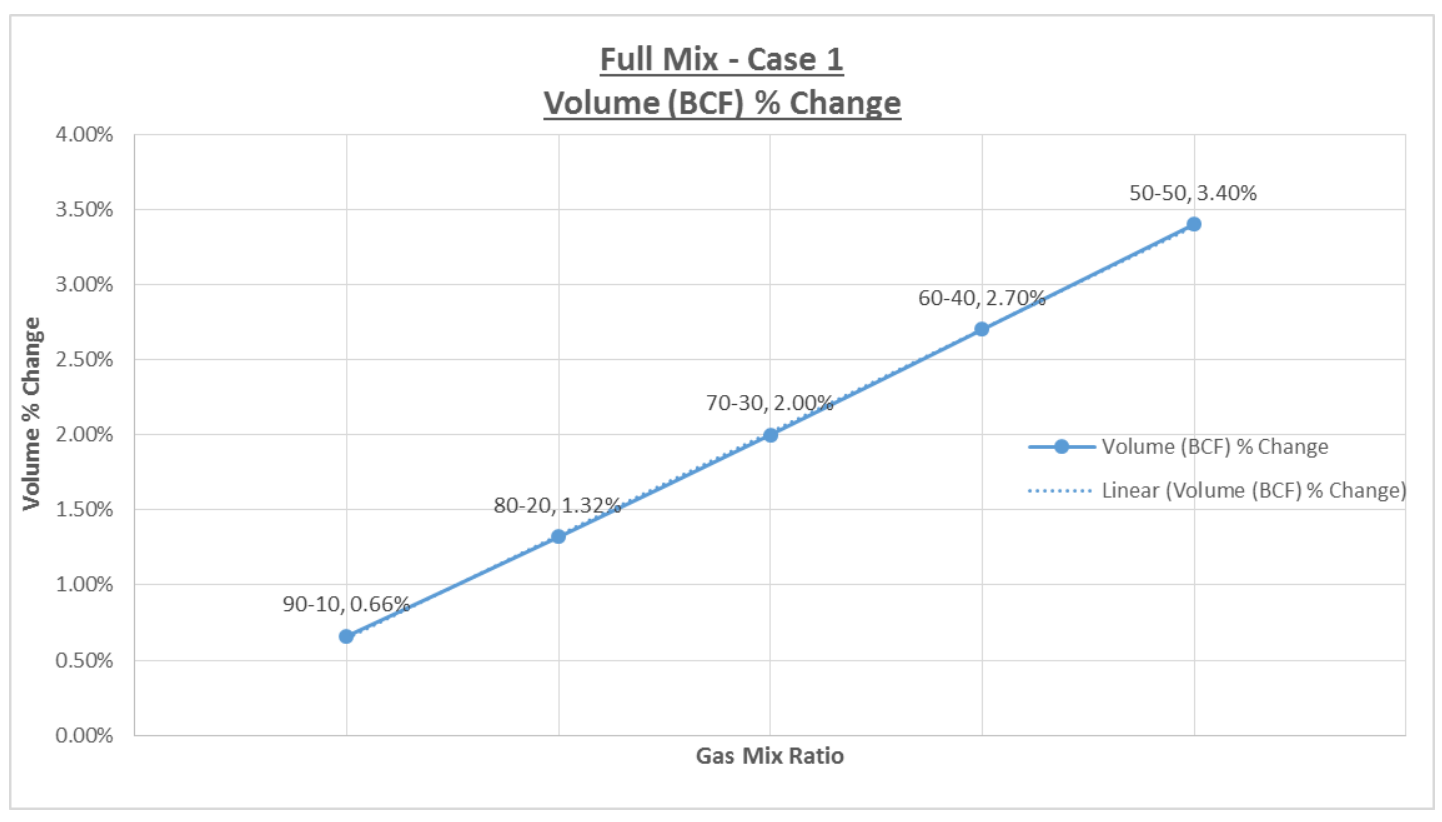

Figure 2 - Case 1: Full Mix - Volume \% Change - Intermediate Size and Pressure Reservoir 


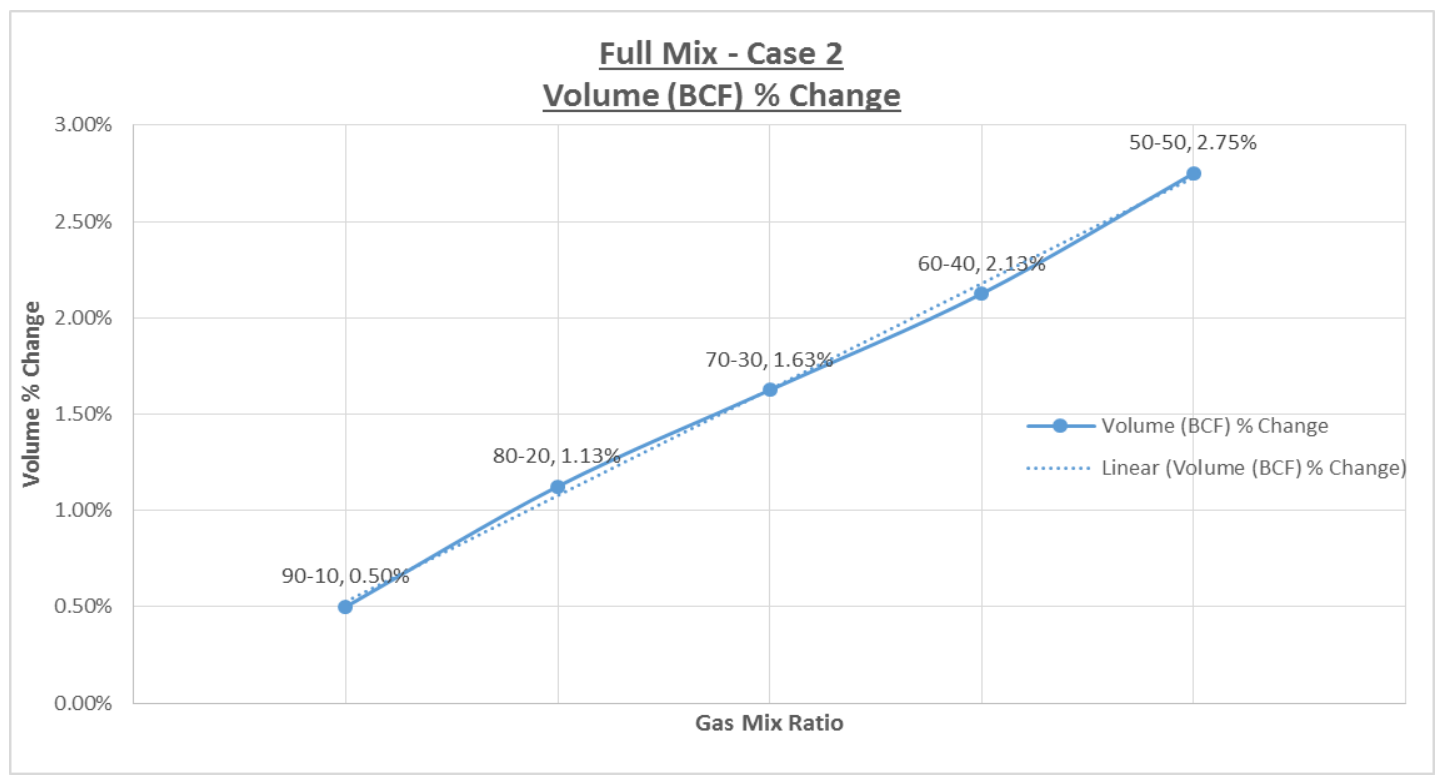

Figure 3-Case 2: Full Mix - Volume \% Change - Small High-Pressure Reservoir

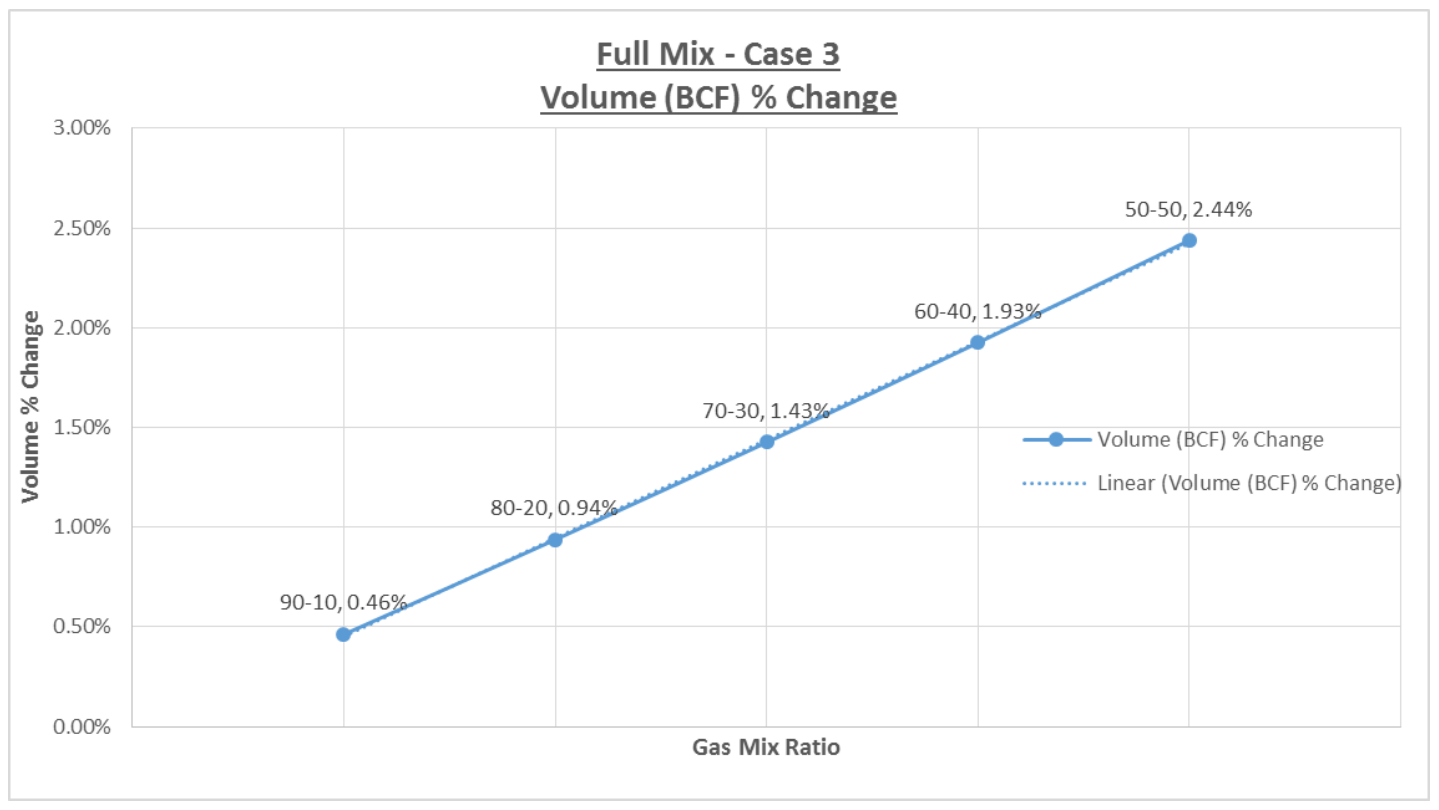

Figure 4-Case 3: Full Mix - Volume \% Change - Large Low-Pressure Reservoir 


\subsection{Working Gas Volume: No Mixing}

The working gas volume required to fill the pore volume of the storage reservoir, excluding the base gas pore volume, at the top storage pressure for storage reservoir cases 1,2 , and 3 are summarized in Tables 12, 13, and 14. In addition, the percentage change in working gas volume as compared to the original working gas volume are summarized in each table.

Table 12 - Case 1: No Mixing - Volume \% Change - Intermediate Size and Pressure Reservoir

\begin{tabular}{|c|c|c|c|}
\hline \multicolumn{4}{|c|}{ Case 1: No Mixing - Volume \% Change } \\
\hline $\begin{array}{c}\text { Mix Ratio } \\
\text { (Base:Working) }\end{array}$ & $\begin{array}{c}\text { Initial Volume } \\
\text { (BCF) }\end{array}$ & $\begin{array}{c}\text { New Volume } \\
\text { (BCF) }\end{array}$ & \% Change \\
\hline $90-10$ & 55.00 & 55.66 & $1.20 \%$ \\
\hline $80-20$ & 55.00 & 56.34 & $2.44 \%$ \\
\hline $70-30$ & 55.00 & 57.05 & $3.73 \%$ \\
\hline $60-40$ & 55.00 & 57.79 & $5.07 \%$ \\
\hline $50-50$ & 55.00 & 58.56 & $6.47 \%$ \\
\hline
\end{tabular}

Table 13 - Case 2: No Mixing - Volume \% Change - Small High-Pressure Reservoir

\begin{tabular}{|c|c|c|c|}
\hline \multicolumn{4}{|c|}{ Case 2: No Mixing - Volume \% Change } \\
\hline $\begin{array}{c}\text { Mix Ratio } \\
\text { (Base:Working) }\end{array}$ & $\begin{array}{c}\text { Initial Volume } \\
\text { (BCF) }\end{array}$ & $\begin{array}{c}\text { New Volume } \\
\text { (BCF) }\end{array}$ & $\%$ Change \\
\hline $90-10$ & 4.00 & 4.04 & $1.00 \%$ \\
\hline $80-20$ & 4.00 & 4.09 & $2.25 \%$ \\
\hline $70-30$ & 4.00 & 4.13 & $3.25 \%$ \\
\hline $60-40$ & 4.00 & 4.18 & $4.50 \%$ \\
\hline $50-50$ & 4.00 & 4.22 & $5.50 \%$ \\
\hline
\end{tabular}

Table 14 - Case 3: No Mixing - Volume \% Change - Large Low-Pressure Reservoir

\begin{tabular}{|c|c|c|c|}
\hline \multicolumn{4}{|c|}{ Case 3: No Mixing - Volume \% Change } \\
\hline $\begin{array}{c}\text { Mix Ratio } \\
\text { (Base:Working) }\end{array}$ & $\begin{array}{c}\text { Initial Volume } \\
\text { (BCF) }\end{array}$ & $\begin{array}{c}\text { New Volume } \\
\text { (BCF) }\end{array}$ & \% Change \\
\hline $90-10$ & 85.00 & 85.75 & $0.88 \%$ \\
\hline $80-20$ & 85.00 & 86.53 & $1.80 \%$ \\
\hline $70-30$ & 85.00 & 87.36 & $2.78 \%$ \\
\hline $60-40$ & 85.00 & 88.22 & $3.79 \%$ \\
\hline $50-50$ & 85.00 & 89.13 & $4.86 \%$ \\
\hline
\end{tabular}


For all following cases, as the ratio of shale gas to the original gas in the mixture (working gas) was increased, the volume required to fill the pore volume of the reservoir increased. The percent change increased linearly for every case as illustrated in Figures 5, 6, and 7.

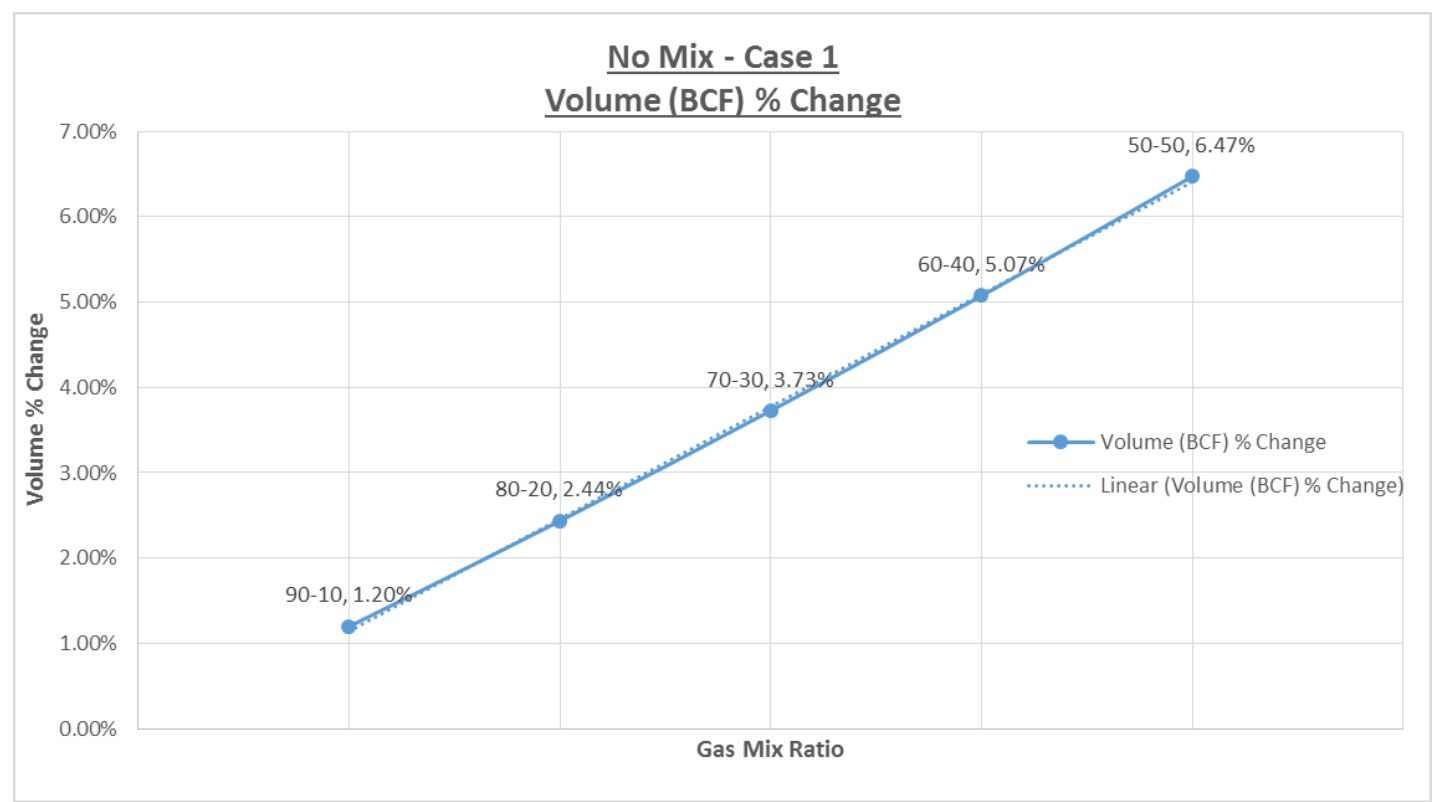

Figure 5 - Case 1: No Mixing - Volume \% Change - Intermediate Size and Pressure Reservoir

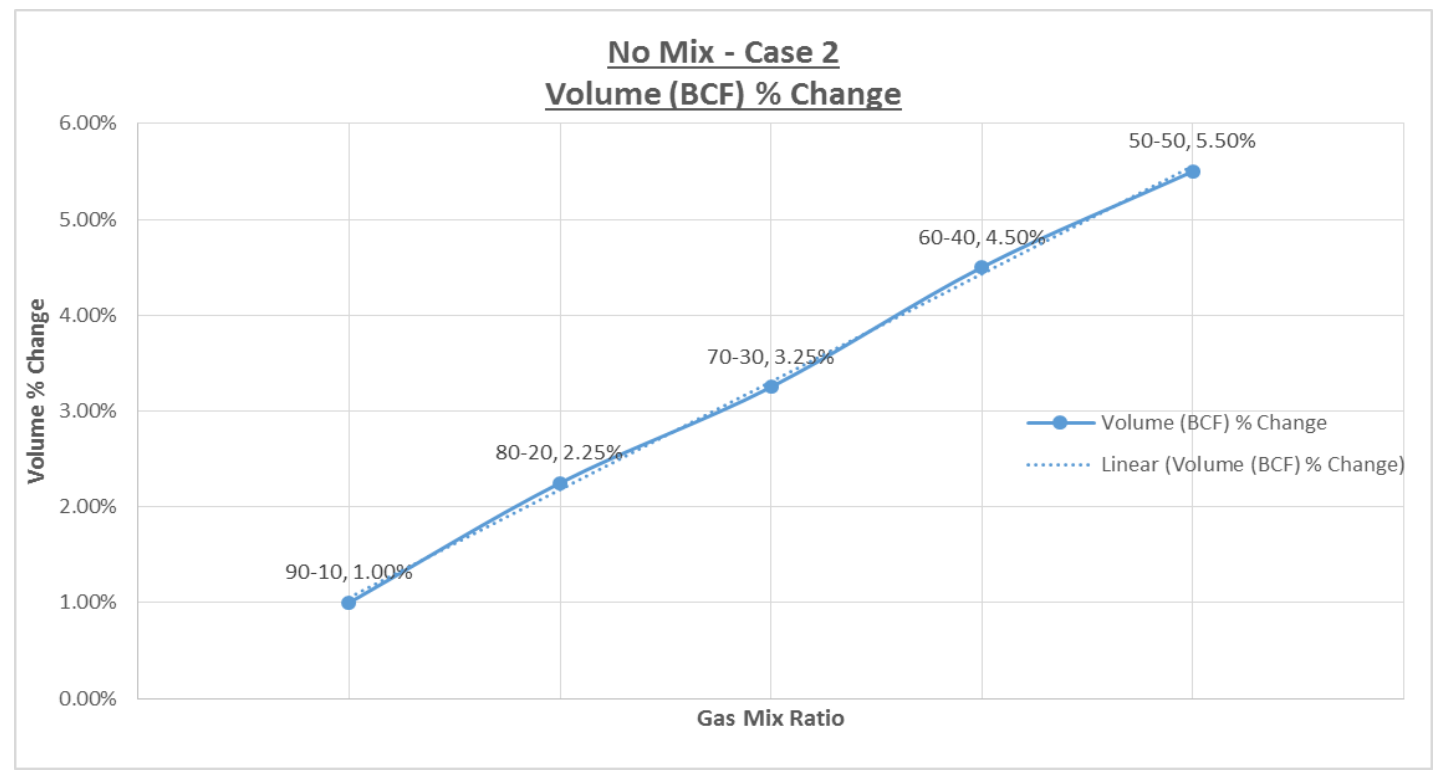

Figure 6 - Case 2: No Mixing - Volume \% Change - Small High-Pressure Reservoir 


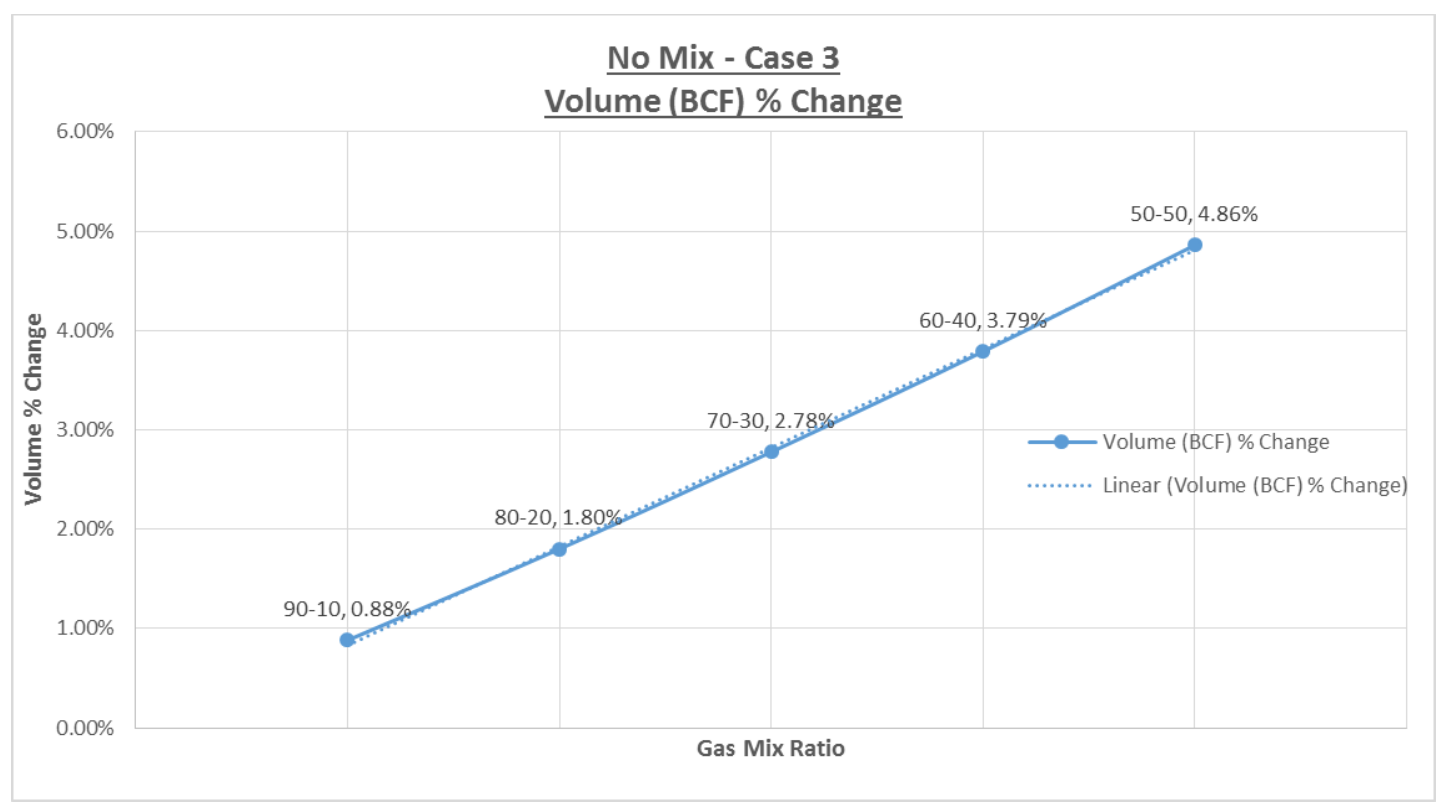

Figure 7 - Case 3: No Mixing - Volume \% Change - Large Low-Pressure Reservoir

\subsection{Storage Pressure: Full Mixing}

The calculated top storage pressure based on the original working gas volume for reservoir cases 1, 2, and 3 are summarized in Table 15, 16, and 17. The percentage change in top storage pressure for the working gas mixture compared to the original top storage pressure are also listed in each table.

Table 15 - Case 1: Full Mix - Pressure \% Change - Intermediate Size and Pressure Reservoir

\begin{tabular}{|c|c|c|c|}
\hline \multicolumn{4}{|c|}{ Case 1: Full Mix - Pressure \% Change } \\
\hline $\begin{array}{c}\text { Mix Ratio } \\
\text { (Base:Working) }\end{array}$ & $\begin{array}{c}\text { Initial Pressure } \\
\text { (psia) }\end{array}$ & $\begin{array}{c}\text { New Pressure } \\
\text { (psia) }\end{array}$ & \% Change \\
\hline $90-10$ & 2250.00 & 2236.00 & $-0.62 \%$ \\
\hline $80-20$ & 2250.00 & 2222.00 & $-1.24 \%$ \\
\hline $70-30$ & 2250.00 & 2208.00 & $-1.87 \%$ \\
\hline $60-40$ & 2250.00 & 2194.00 & $-2.49 \%$ \\
\hline $50-50$ & 2250.00 & 2180.00 & $-3.11 \%$ \\
\hline
\end{tabular}


Table 16 - Case 2: Full Mix - Pressure \% Change - Small High-Pressure Reservoir

\begin{tabular}{|c|c|c|c|}
\hline \multicolumn{4}{|c|}{ Case 2: Full Mix - Pressure \% Change } \\
\hline $\begin{array}{c}\text { Mix Ratio } \\
\text { (Base:Working) }\end{array}$ & $\begin{array}{c}\text { Initial Pressure } \\
\text { (psia) }\end{array}$ & $\begin{array}{c}\text { New Pressure } \\
\text { (psia) }\end{array}$ & \% Change \\
\hline $90-10$ & 2700.00 & 2685.00 & $-0.56 \%$ \\
\hline $80-20$ & 2700.00 & 2670.00 & $-1.11 \%$ \\
\hline $70-30$ & 2700.00 & 2657.00 & $-1.59 \%$ \\
\hline $60-40$ & 2700.00 & 2640.00 & $-2.22 \%$ \\
\hline $50-50$ & 2700.00 & 2626.00 & $-2.74 \%$ \\
\hline
\end{tabular}

Table 17 - Case 3: Full Mix - Pressure \% Change - Large Low-Pressure Reservoir

\begin{tabular}{|c|c|c|c|}
\hline \multicolumn{4}{|c|}{ Case 3: Full Mix - Pressure \% Change } \\
\hline $\begin{array}{c}\text { Mix Ratio } \\
\text { (Base:Working) }\end{array}$ & $\begin{array}{c}\text { Initial Pressure } \\
\text { (psia) }\end{array}$ & $\begin{array}{c}\text { New Pressure } \\
\text { (psia) }\end{array}$ & \% Change \\
\hline $90-10$ & 1100.00 & 1095.00 & $-0.45 \%$ \\
\hline $80-20$ & 1100.00 & 1091.00 & $-0.82 \%$ \\
\hline $70-30$ & 1100.00 & 1086.00 & $-1.27 \%$ \\
\hline $60-40$ & 1100.00 & 1082.00 & $-1.64 \%$ \\
\hline $50-50$ & 1100.00 & 1077.00 & $-2.09 \%$ \\
\hline
\end{tabular}

For all following cases, as the ratio of shale gas to the original gas in the mixture (working gas) was increased, the percentage change in top storage pressure compared to the original top storage pressure decreased. The percent change decreased linearly for every case as illustrated in Figures $8,9,10$. 


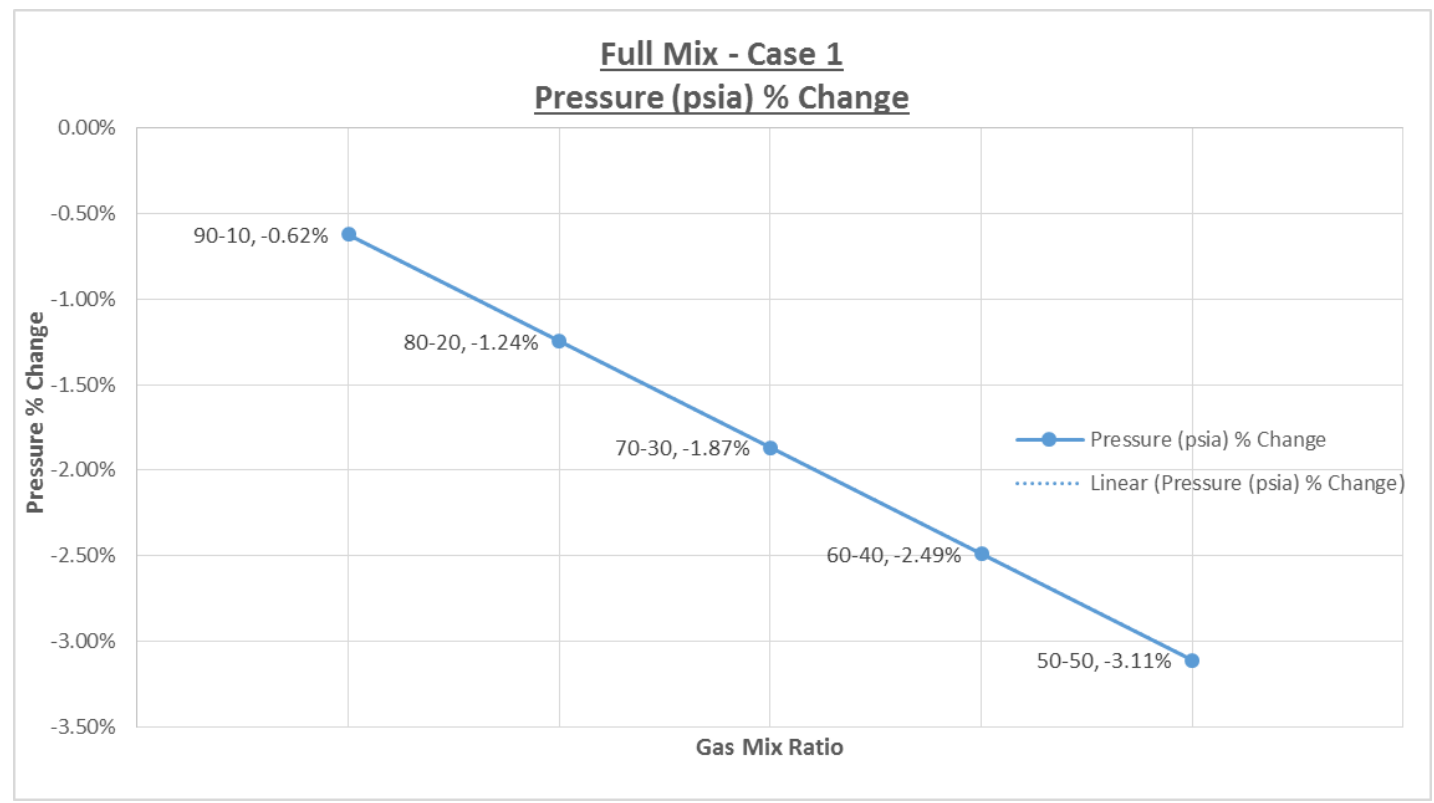

Figure 8 - Case 1: Full Mix - Pressure \% Change - Intermediate Size and Pressure Reservoir

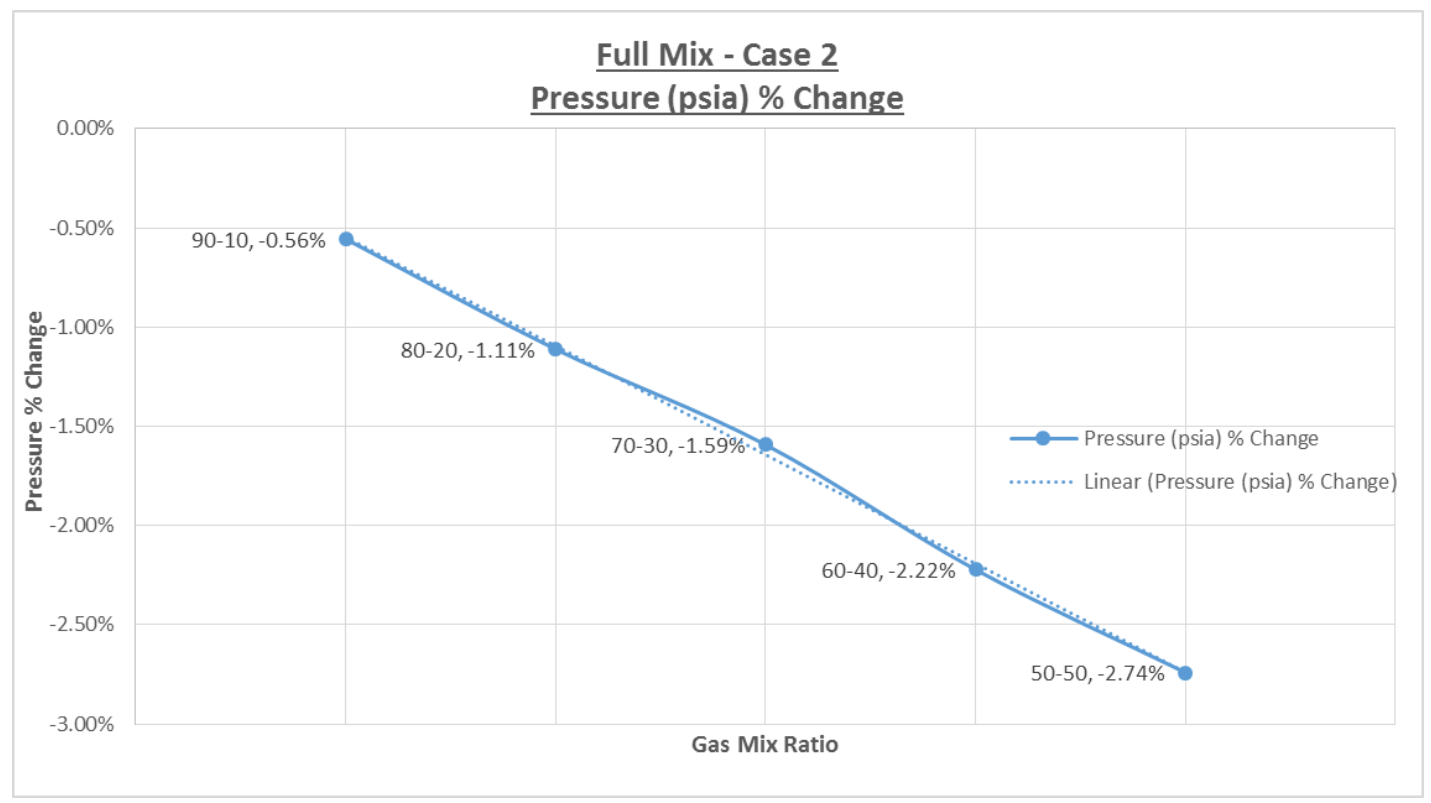

Figure 9 - Case 2: Full Mix - Pressure \% Change - Small High-Pressure Reservoir 


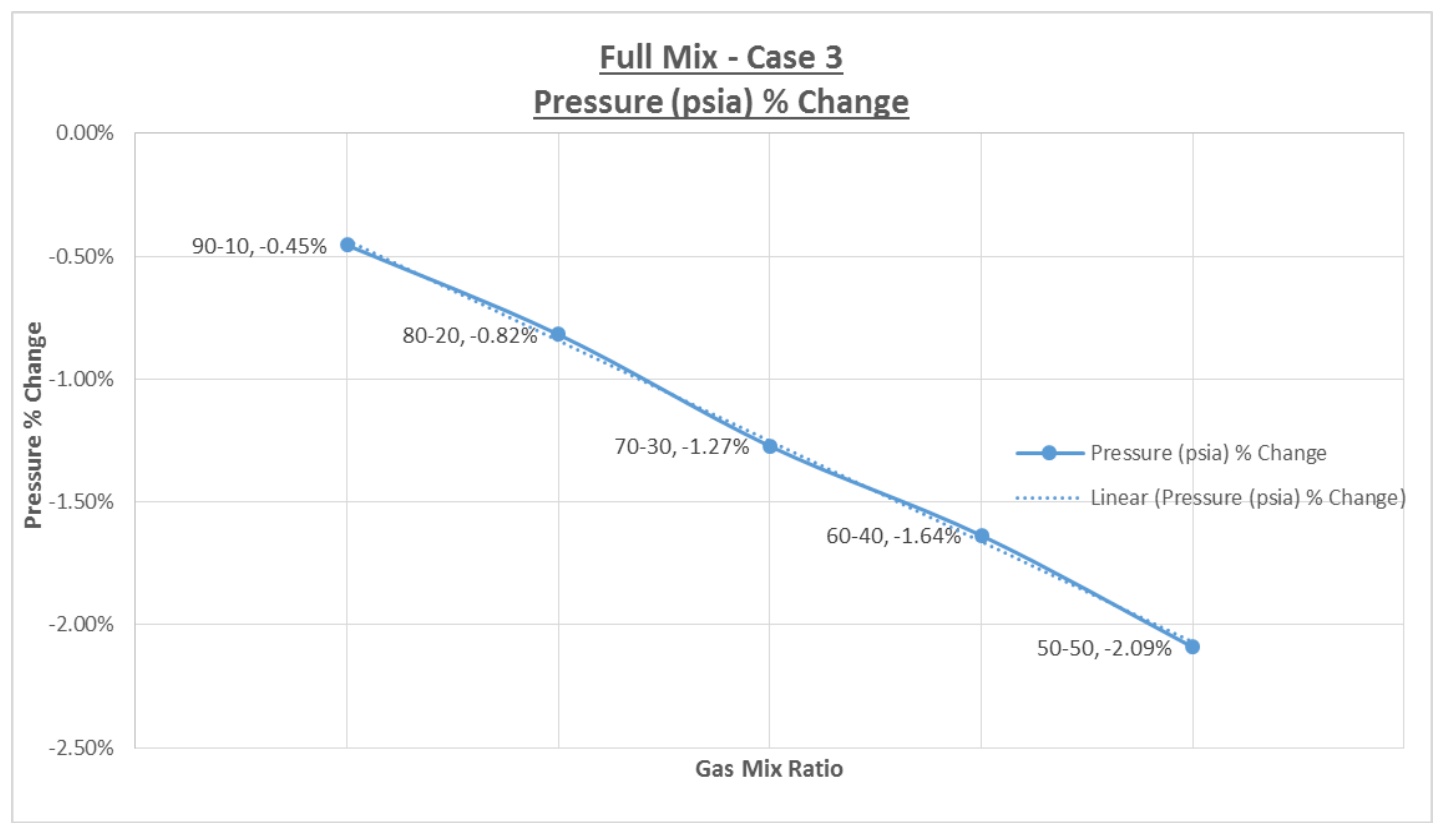

Figure 10 - Case 3: Full Mix - Pressure \% Change - Large Low-Pressure Reservoir

\subsection{Storage Pressure: No Mixing}

The calculated top storage pressure based on the original working gas volume for reservoir cases 1, 2, and 3 are summarized in Table 18, 19, and 20. The percentage changes in top storage pressure for the working gas mixture compared to the original top storage pressure are also listed in each table.

Table 18 - Case 1: No Mixing - Pressure \% Change - Intermediate Size and Pressure Reservoir

\begin{tabular}{|c|c|c|c|}
\hline \multicolumn{4}{|c|}{ Case 1: No Mixing - Pressure \% Change } \\
\hline $\begin{array}{c}\text { Mix Ratio } \\
\text { (Base:Working) }\end{array}$ & $\begin{array}{c}\text { Initial Pressure } \\
\text { (psia) }\end{array}$ & $\begin{array}{c}\text { New Pressure } \\
\text { (psia) }\end{array}$ & \% Change \\
\hline $90-10$ & 2250.00 & 2237.00 & $-0.58 \%$ \\
\hline $80-20$ & 2250.00 & 2220.00 & $-1.33 \%$ \\
\hline $70-30$ & 2250.00 & 2205.00 & $-2.00 \%$ \\
\hline $60-40$ & 2250.00 & 2193.00 & $-2.53 \%$ \\
\hline $50-50$ & 2250.00 & 2179.00 & $-3.16 \%$ \\
\hline
\end{tabular}


Table 19 - Case 2: No Mixing - Pressure \% Change - Small High-Pressure Reservoir

\begin{tabular}{|c|c|c|c|}
\hline \multicolumn{4}{|c|}{ Case 2: No Mixing - Pressure \% Change } \\
\hline $\begin{array}{c}\text { Mix Ratio } \\
\text { (Base:Working) }\end{array}$ & $\begin{array}{c}\text { Initial Pressure } \\
\text { (psia) }\end{array}$ & $\begin{array}{c}\text { New Pressure } \\
\text { (psia) }\end{array}$ & \% Change \\
\hline $90-10$ & 2700.00 & 2690.00 & $-0.37 \%$ \\
\hline $80-20$ & 2700.00 & 2670.00 & $-1.11 \%$ \\
\hline $70-30$ & 2700.00 & 2655.00 & $-1.67 \%$ \\
\hline $60-40$ & 2700.00 & 2642.00 & $-2.15 \%$ \\
\hline $50-50$ & 2700.00 & 2628.00 & $-2.67 \%$ \\
\hline
\end{tabular}

Table 20 - Case 3: No Mixing - Pressure \% Change - Large Low-Pressure Reservoir

\begin{tabular}{|c|c|c|c|}
\hline \multicolumn{4}{|c|}{ Case 3: No Mixing - Pressure \% Change } \\
\hline $\begin{array}{c}\text { Mix Ratio } \\
\text { (Base:Working) }\end{array}$ & $\begin{array}{c}\text { Initial Pressure } \\
\text { (psia) }\end{array}$ & $\begin{array}{c}\text { New Pressure } \\
\text { (psia) }\end{array}$ & \% Change \\
\hline $90-10$ & 1100.00 & 1096.00 & $-0.36 \%$ \\
\hline $80-20$ & 1100.00 & 1091.00 & $-0.82 \%$ \\
\hline $70-30$ & 1100.00 & 1087.00 & $-1.18 \%$ \\
\hline $60-40$ & 1100.00 & 1082.00 & $-1.64 \%$ \\
\hline $50-50$ & 1100.00 & 1077.00 & $-2.09 \%$ \\
\hline
\end{tabular}

For all following cases, as the ratio of shale gas to the original gas in the mixture (working gas) was increased, the percentage change in top storage pressure compared to the original top storage pressure decreased. The percent change decreased linearly for every case as illustrated in Figures 11, 12, and 13. 


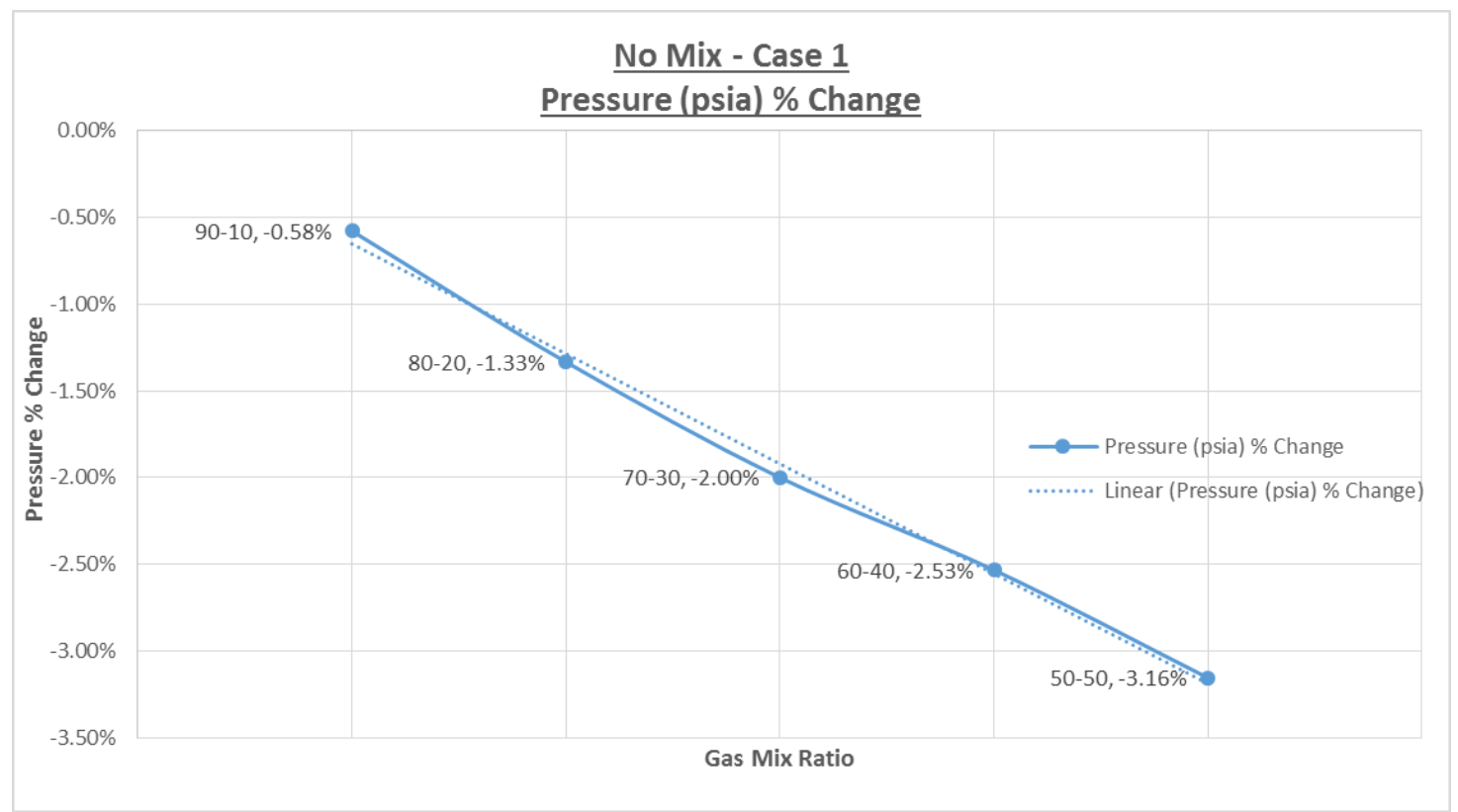

Figure 11 - Case 1: No Mixing - Pressure \% Change - Intermediate Size and Pressure Reservoir

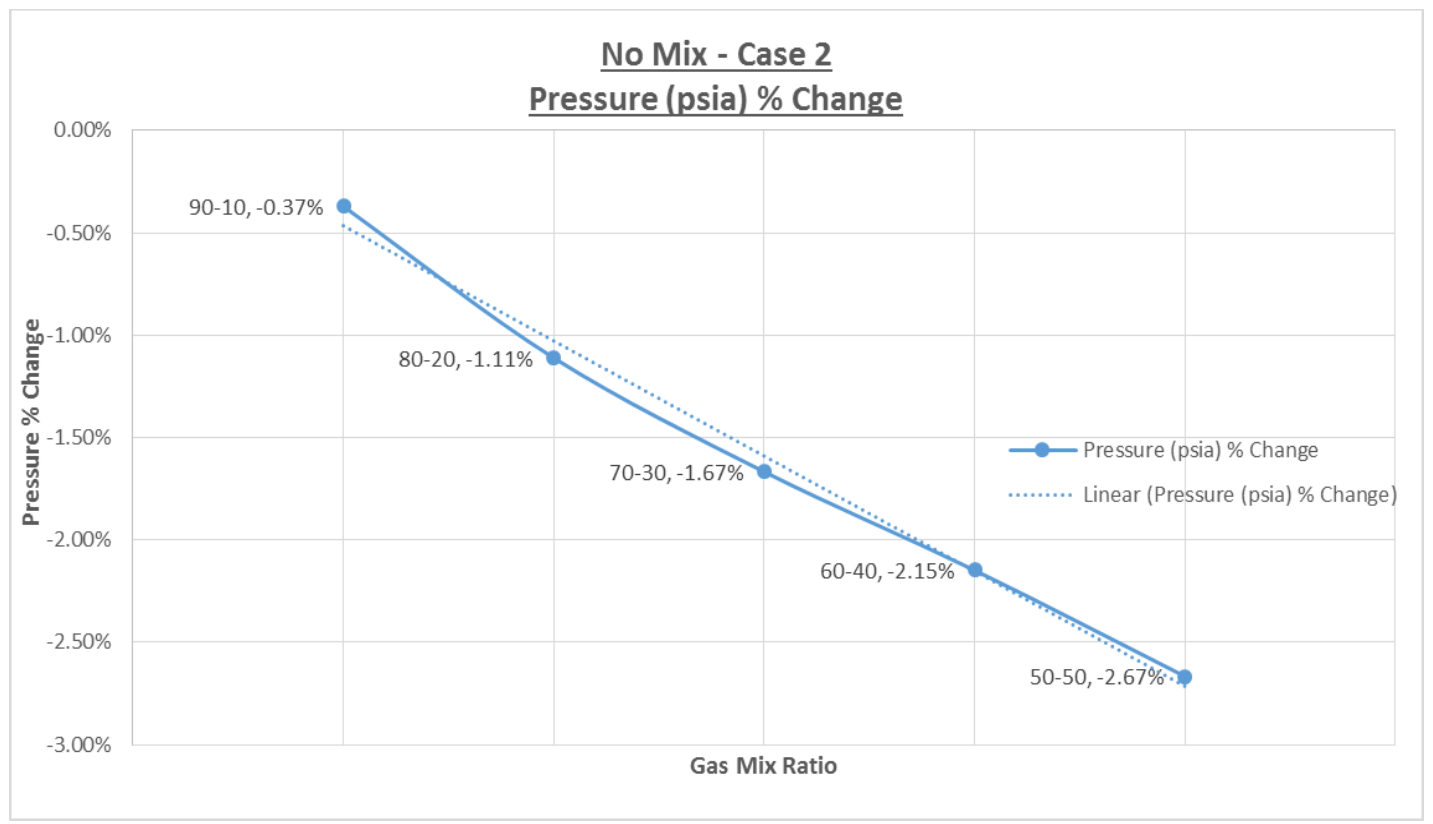

Figure 12 - Case 2: No Mixing - Pressure \% Change - Small High-Pressure Reservoir 


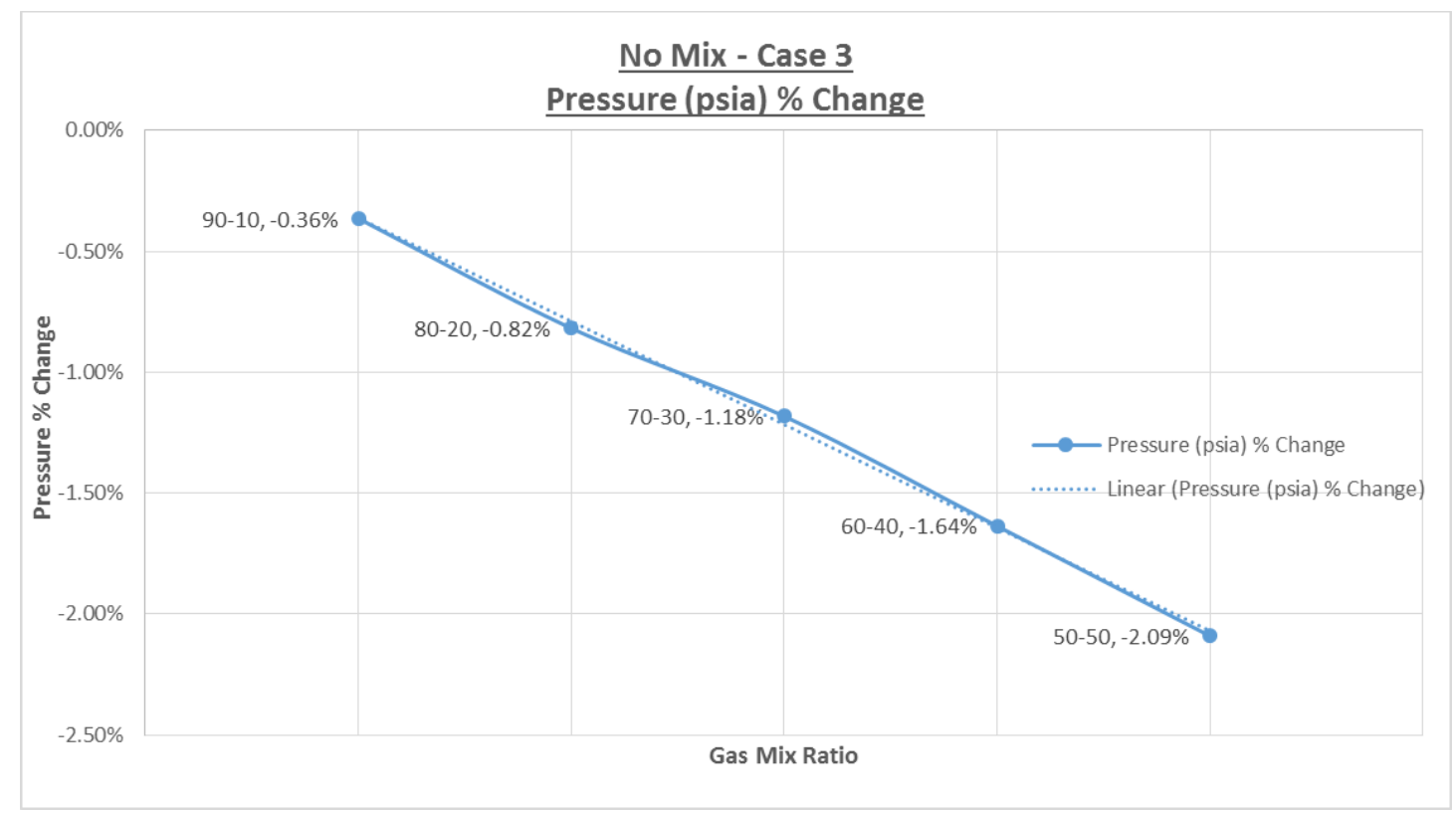

Figure 13 - Case 3: No Mixing - Pressure \% Change - Large Low-Pressure Reservoir

\subsection{Withdrawal Rate: Full Mix}

The calculated gas withdrawal rate for a drawdown of $400 \mathrm{psi}$ at the top storage pressure for the working gas mixture for reservoir cases 1 , 2, and 3 are summarized in tables 21, 22, and 23. The percentage changes in withdrawal rate compared to the original withdrawal rate are also listed in each table.

Table 21 - Case 1: Full Mix - Withdrawal Rate \% Change - Intermediate Size and Pressure Reservoir

\begin{tabular}{|c|c|c|c|}
\hline \multicolumn{4}{|c|}{ Case 1: Full Mix - Withdrawal Rate \% Change } \\
\hline $\begin{array}{c}\text { Mix Ratio } \\
\text { (Base:Working) }\end{array}$ & $\begin{array}{c}\text { Initial Withdrawal Rate } \\
\text { (MMCFD) }\end{array}$ & $\begin{array}{c}\text { New Withdrawal Rate } \\
\text { (MMCFD) }\end{array}$ & \% Change \\
\hline $90-10$ & 36.75 & 36.44 & $-0.84 \%$ \\
\hline $80-20$ & 36.75 & 36.14 & $-1.66 \%$ \\
\hline $70-30$ & 36.75 & 35.85 & $-2.45 \%$ \\
\hline $60-40$ & 36.75 & 35.57 & $-3.21 \%$ \\
\hline $50-50$ & 36.75 & 35.30 & $-3.94 \%$ \\
\hline
\end{tabular}


Table 22 - Case 2: Full Mix - Withdrawal Rate \% Change - Small High-Pressure Reservoir

\begin{tabular}{|c|c|c|c|}
\hline \multicolumn{4}{|c|}{ Case 2: Full Mix - Withdrawal Rate \% Change } \\
\hline $\begin{array}{c}\text { Mix Ratio } \\
\text { (Base:Working) }\end{array}$ & $\begin{array}{c}\text { Initial Withdrawal Rate } \\
\text { (MMCFD) }\end{array}$ & $\begin{array}{c}\text { New Withdrawal Rate } \\
\text { (MMCFD) }\end{array}$ & $\%$ Change \\
\hline $90-10$ & 41.43 & 39.32 & $-5.09 \%$ \\
\hline $80-20$ & 41.43 & 38.96 & $-5.96 \%$ \\
\hline $70-30$ & 41.43 & 38.63 & $-6.76 \%$ \\
\hline $60-40$ & 41.43 & 38.27 & $-7.63 \%$ \\
\hline $50-50$ & 41.43 & 37.95 & $-8.40 \%$ \\
\hline
\end{tabular}

Table 23 - Case 3: Full Mix - Withdrawal Rate \% Change - Large Low-Pressure Reservoir

\begin{tabular}{|c|c|c|c|}
\hline \multicolumn{4}{|c|}{ Case 3: Full Mix - Withdrawal Rate \% Change } \\
\hline $\begin{array}{c}\text { Mix Ratio } \\
\text { (Base:Working) }\end{array}$ & $\begin{array}{c}\text { Initial Withdrawal Rate } \\
\text { (MMCFD) }\end{array}$ & $\begin{array}{c}\text { New Withdrawal Rate } \\
\text { (MMCFD) }\end{array}$ & \% Change \\
\hline $90-10$ & 21.65 & 21.55 & $-0.46 \%$ \\
\hline $80-20$ & 21.65 & 21.47 & $-0.85 \%$ \\
\hline $70-30$ & 21.65 & 21.37 & $-1.31 \%$ \\
\hline $60-40$ & 21.65 & 21.29 & $-1.68 \%$ \\
\hline $50-50$ & 21.65 & 21.19 & $-2.13 \%$ \\
\hline
\end{tabular}

For all following cases, as the ratio of shale gas to the original gas in the mixture (working gas) was increased, the percentage change in withdrawal rate compared to original withdrawal rate decreased. The percent change decreased linearly for every case as illustrated in Figures 14, 15 and 16 . 


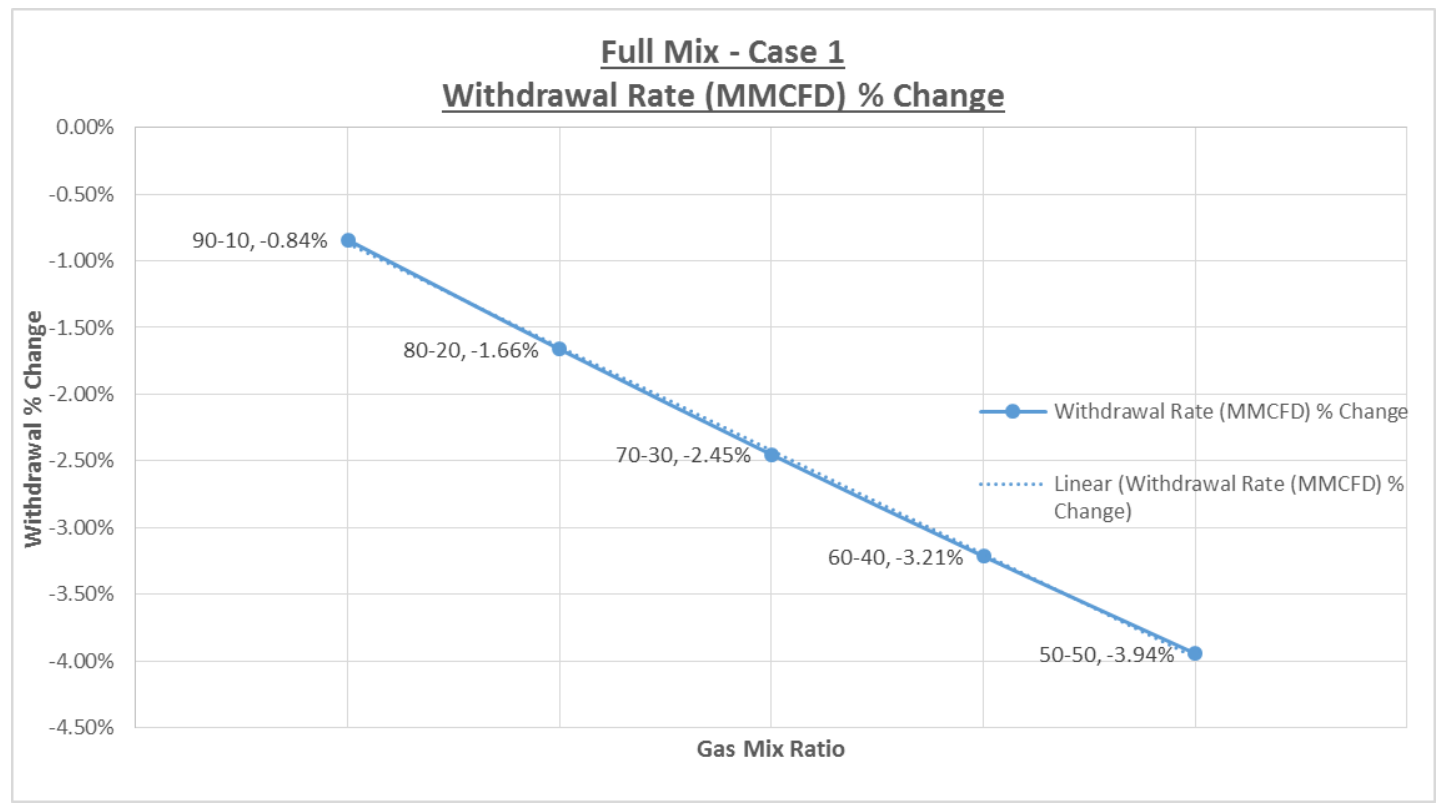

Figure 14 - Case 1: Full Mix - Withdrawal Rate \% Change - Intermediate Size and Pressure Reservoir

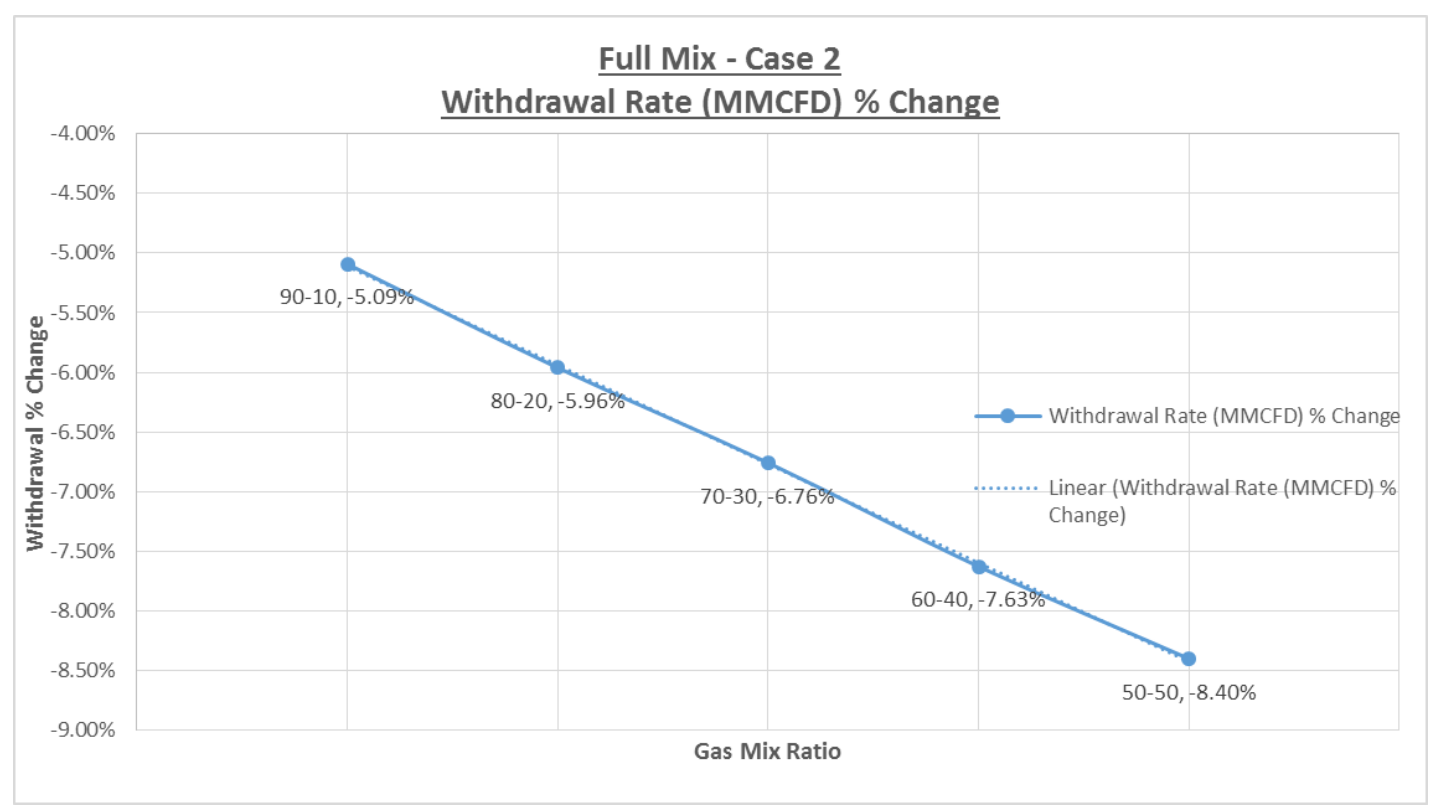

Figure 15 - Case 2: Full Mix - Withdrawal Rate \% Change - Small High-Pressure Reservoir 


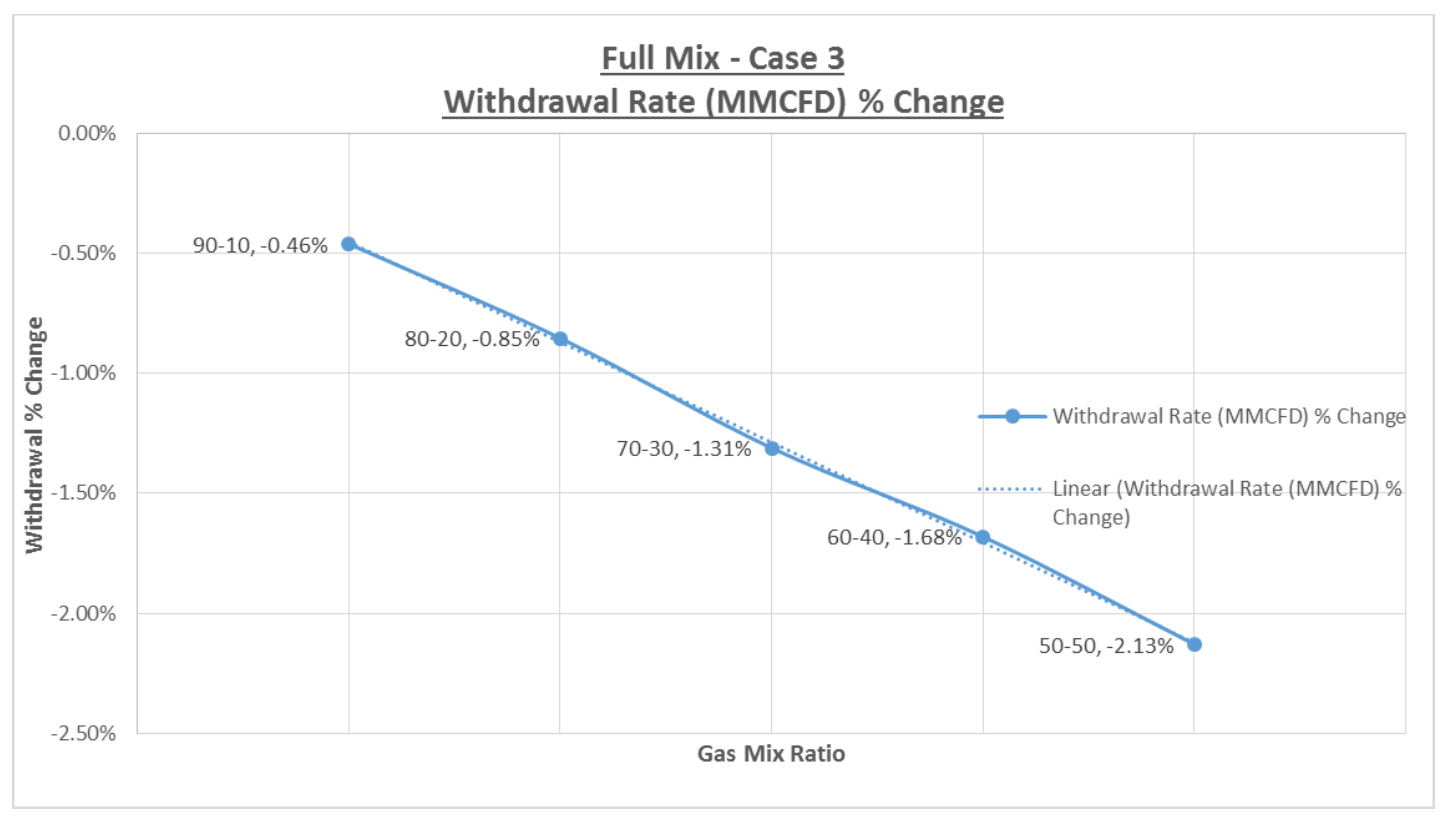

Figure 16 - Case 3: Full Mix - Withdrawal Rate \% Change - Large Low-Pressure Reservoir

\subsection{Withdrawal Rate: No Mix}

The calculated gas withdrawal rate for a drawdown of $400 \mathrm{psi}$ at the top storage pressure for the working gas mixture for reservoir cases 1, 2, and 3 are summarized in tables 24, 25, and 26. The percentage changes in withdrawal rate compared to the original withdrawal rate are also listed in each table.

Table 24 - Case 1: No Mixing - Withdrawal Rate \% Change - Intermediate Size and Pressure Reservoir

\begin{tabular}{|c|c|c|c|}
\hline \multicolumn{4}{|c|}{ Case 1: No Mixing - Withdrawal Rate \% Change } \\
\hline $\begin{array}{c}\text { Mix Ratio } \\
\text { (Base:Working) }\end{array}$ & $\begin{array}{c}\text { Initial Withdrawal Rate } \\
\text { (MMCFD) }\end{array}$ & $\begin{array}{c}\text { New Withdrawal Rate } \\
\text { (MMCFD) }\end{array}$ & $\%$ Change \\
\hline $90-10$ & 36.75 & 36.45 & $-0.82 \%$ \\
\hline $80-20$ & 36.75 & 36.13 & $-1.68 \%$ \\
\hline $70-30$ & 36.75 & 35.82 & $-2.54 \%$ \\
\hline $60-40$ & 36.75 & 35.56 & $-3.24 \%$ \\
\hline $50-50$ & 36.75 & 35.29 & $-3.97 \%$ \\
\hline
\end{tabular}


Table 25 - Case 2: No Mixing - Withdrawal Rate \% Change - Small High-Pressure Reservoir

\begin{tabular}{|c|c|c|c|}
\hline \multicolumn{4}{|c|}{ Case 2: No Mixing - Withdrawal Rate \% Change } \\
\hline $\begin{array}{c}\text { Mix Ratio } \\
\text { (Base:Working) }\end{array}$ & $\begin{array}{c}\text { Initial Withdrawal Rate } \\
\text { (MMCFD) }\end{array}$ & $\begin{array}{c}\text { New Withdrawal Rate } \\
\text { (MMCFD) }\end{array}$ & \% Change \\
\hline $90-10$ & 41.43 & 39.36 & $-5.00 \%$ \\
\hline $80-20$ & 41.43 & 38.96 & $-5.96 \%$ \\
\hline $70-30$ & 41.43 & 38.61 & $-6.80 \%$ \\
\hline $60-40$ & 41.43 & 38.29 & $-7.58 \%$ \\
\hline $50-50$ & 41.43 & 37.96 & $-8.38 \%$ \\
\hline
\end{tabular}

Table 26 - Case 3: No Mixing - Withdrawal Rate \% Change - Large Low-Pressure Reservoir

\begin{tabular}{|c|c|c|c|}
\hline \multicolumn{4}{|c|}{ Case 3: No Mixing - Withdrawal Rate \% Change } \\
\hline $\begin{array}{c}\text { Mix Ratio } \\
\text { (Base:Working) }\end{array}$ & $\begin{array}{c}\text { Initial Withdrawal Rate } \\
\text { (MMCFD) }\end{array}$ & $\begin{array}{c}\text { New Withdrawal Rate } \\
\text { (MMCFD) }\end{array}$ & \% Change \\
\hline $90-10$ & 21.85 & 21.76 & $-0.41 \%$ \\
\hline $80-20$ & 21.85 & 21.65 & $-0.91 \%$ \\
\hline $70-30$ & 21.85 & 21.56 & $-1.32 \%$ \\
\hline $60-40$ & 21.85 & 21.46 & $-1.80 \%$ \\
\hline $50-50$ & 21.85 & 21.36 & $-2.27 \%$ \\
\hline
\end{tabular}

For all following cases, as the ratio of shale gas to the original gas in the mixture (working gas) was increased, the percentage change in withdrawal rate compared to original withdrawal rate decreased. The percent change decreased linearly for every case as illustrated in Figures 17, 18 and 19. 


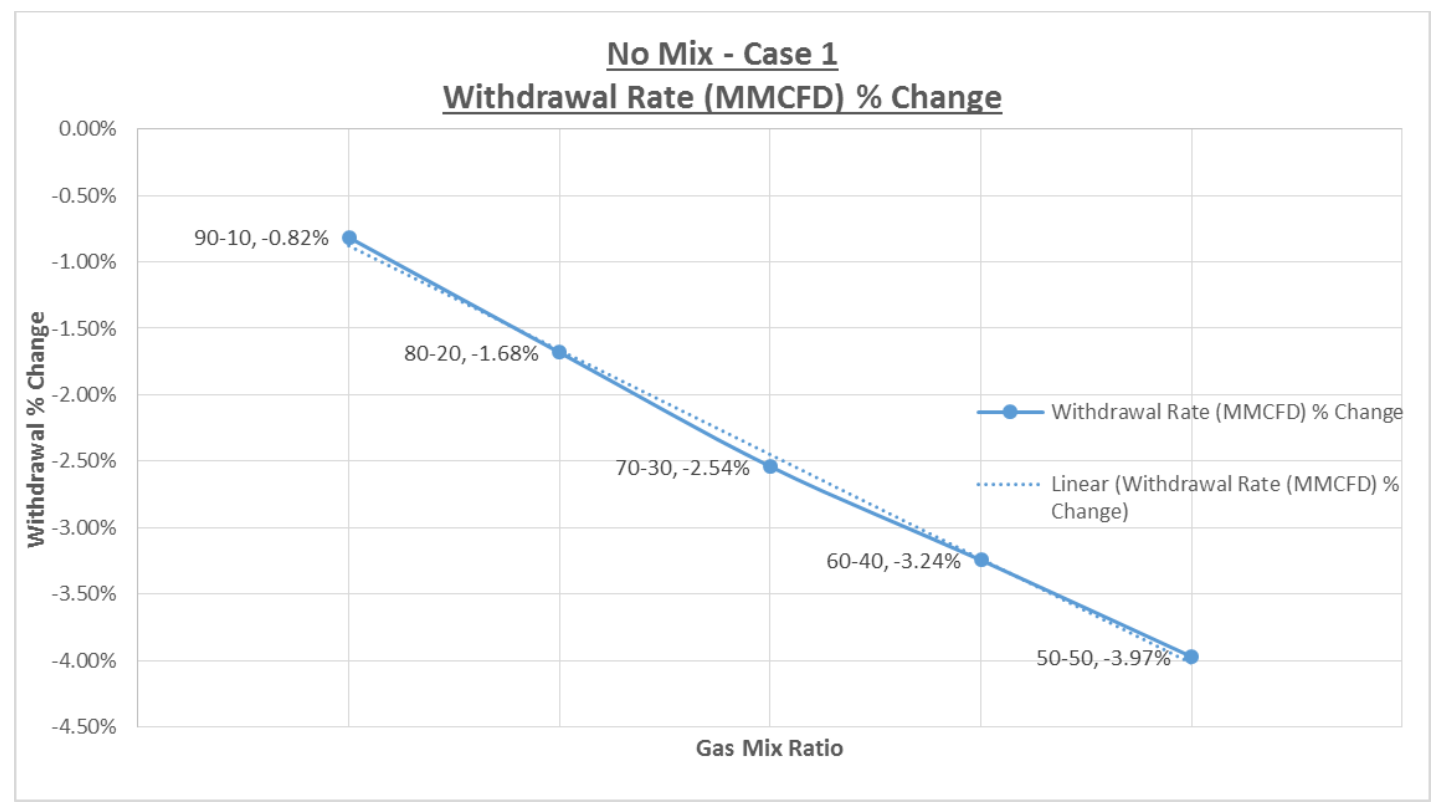

Figure 17 - Case 1: No Mixing - Withdrawal Rate \% Change - Intermediate Size and Pressure Reservoir

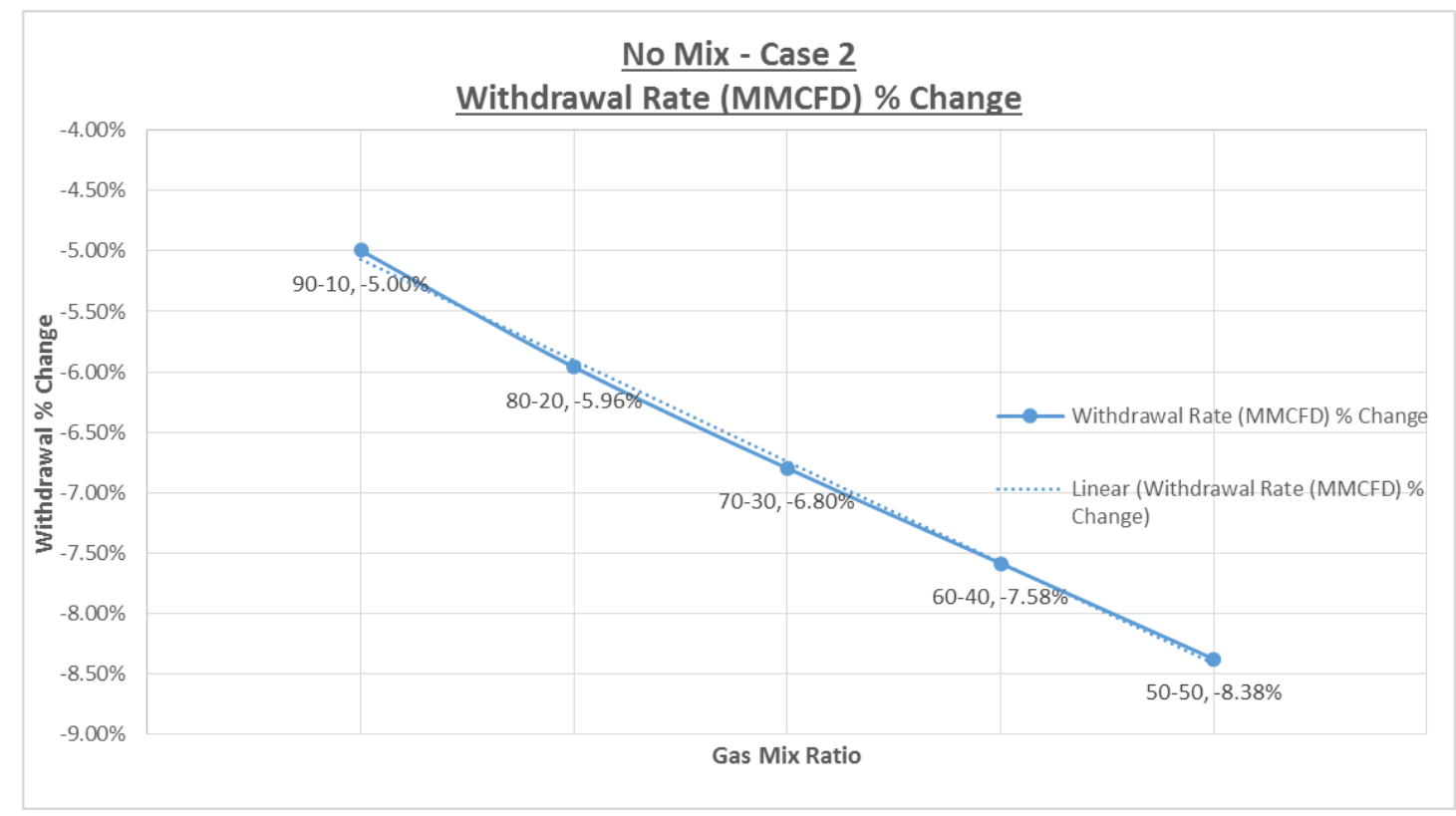

Figure 18 - Case 2: No Mixing - Withdrawal Rate \% Change - Small High-Pressure Reservoir 


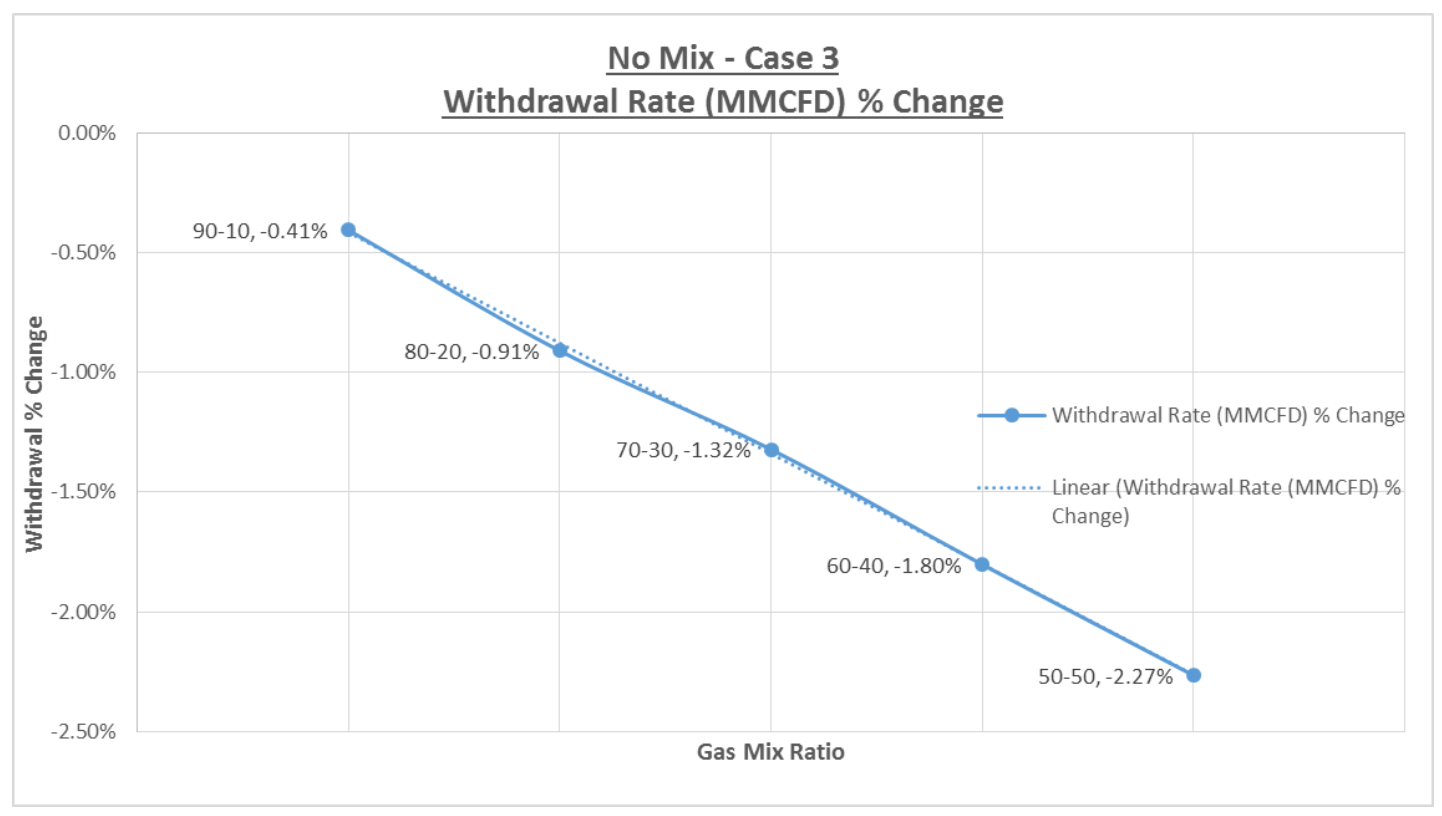

Figure 19 - Case 3: No Mixing - Withdrawal Rate \% Change - Large Low-Pressure Reservoir

\subsection{Drawdown: Full Mixing}

The calculated gas drawdown required to achieve original flow rate (based on 400 psi drawdown using base gas composition) at the top storage pressure for reservoir cases 1, 2, and 3 are summarized in tables 27,28 , and 29. The percentage change in drawdown compared to the original drawdown (400 psi) are also listed in each table.

Table 27- Case 1: Full Mix - Drawdown \% Change - Intermediate Size and Pressure Reservoir

\begin{tabular}{|c|c|c|c|}
\hline \multicolumn{4}{|c|}{ Case 1: Full Mix - Drawdown \% Change } \\
\hline $\begin{array}{c}\text { Mix Ratio } \\
\text { (Base:Working) }\end{array}$ & $\begin{array}{c}\text { Initial Drawdown } \\
\text { (psia) }\end{array}$ & $\begin{array}{c}\text { New Drawdown } \\
\text { (psia) }\end{array}$ & \% Change \\
\hline $90-10$ & 400.00 & 405.00 & $1.25 \%$ \\
\hline $80-20$ & 400.00 & 410.00 & $2.50 \%$ \\
\hline $70-30$ & 400.00 & 415.00 & $3.75 \%$ \\
\hline $60-40$ & 400.00 & 420.00 & $5.00 \%$ \\
\hline $50-50$ & 400.00 & 425.00 & $6.25 \%$ \\
\hline
\end{tabular}


Table 28-Case 2: Full Mix - Drawdown \% Change - Small High-Pressure Reservoir

\begin{tabular}{|c|c|c|c|}
\hline \multicolumn{4}{|c|}{ Case 2: Full Mix - Drawdown \% Change } \\
\hline $\begin{array}{c}\text { Mix Ratio } \\
\text { (Base:Working) }\end{array}$ & $\begin{array}{c}\text { Initial Drawdown } \\
\text { (psia) }\end{array}$ & $\begin{array}{c}\text { New Drawdown } \\
\text { (psia) }\end{array}$ & \% Change \\
\hline $90-10$ & 400.00 & 432.00 & $8.00 \%$ \\
\hline $80-20$ & 400.00 & 438.00 & $9.50 \%$ \\
\hline $70-30$ & 400.00 & 444.00 & $11.00 \%$ \\
\hline $60-40$ & 400.00 & 450.00 & $12.50 \%$ \\
\hline $50-50$ & 400.00 & 456.00 & $14.00 \%$ \\
\hline
\end{tabular}

Table 29 - Case 3: Full Mix-Drawdown \% Change-Large Low-Pressure Reservoir

\begin{tabular}{|c|c|c|c|}
\hline \multicolumn{4}{|c|}{ Case 3: Full Mix - Drawdown \% Change } \\
\hline $\begin{array}{c}\text { Mix Ratio } \\
\text { (Base:Working) }\end{array}$ & $\begin{array}{c}\text { Initial Drawdown } \\
\text { (psia) }\end{array}$ & $\begin{array}{c}\text { New Drawdown } \\
\text { (psia) }\end{array}$ & \% Change \\
\hline $90-10$ & 400.00 & 403.00 & $0.75 \%$ \\
\hline $80-20$ & 400.00 & 406.00 & $1.50 \%$ \\
\hline $70-30$ & 400.00 & 409.00 & $2.25 \%$ \\
\hline $60-40$ & 400.00 & 412.00 & $3.00 \%$ \\
\hline $50-50$ & 400.00 & 415.00 & $3.75 \%$ \\
\hline
\end{tabular}

For all following cases, as the ratio of shale gas to the original gas in the mixture (working gas) was increased, the percentage change in drawdown compared to original drawdown increased. The percent change increased linearly for every case as illustrated in Figures 20, 21 and 22.

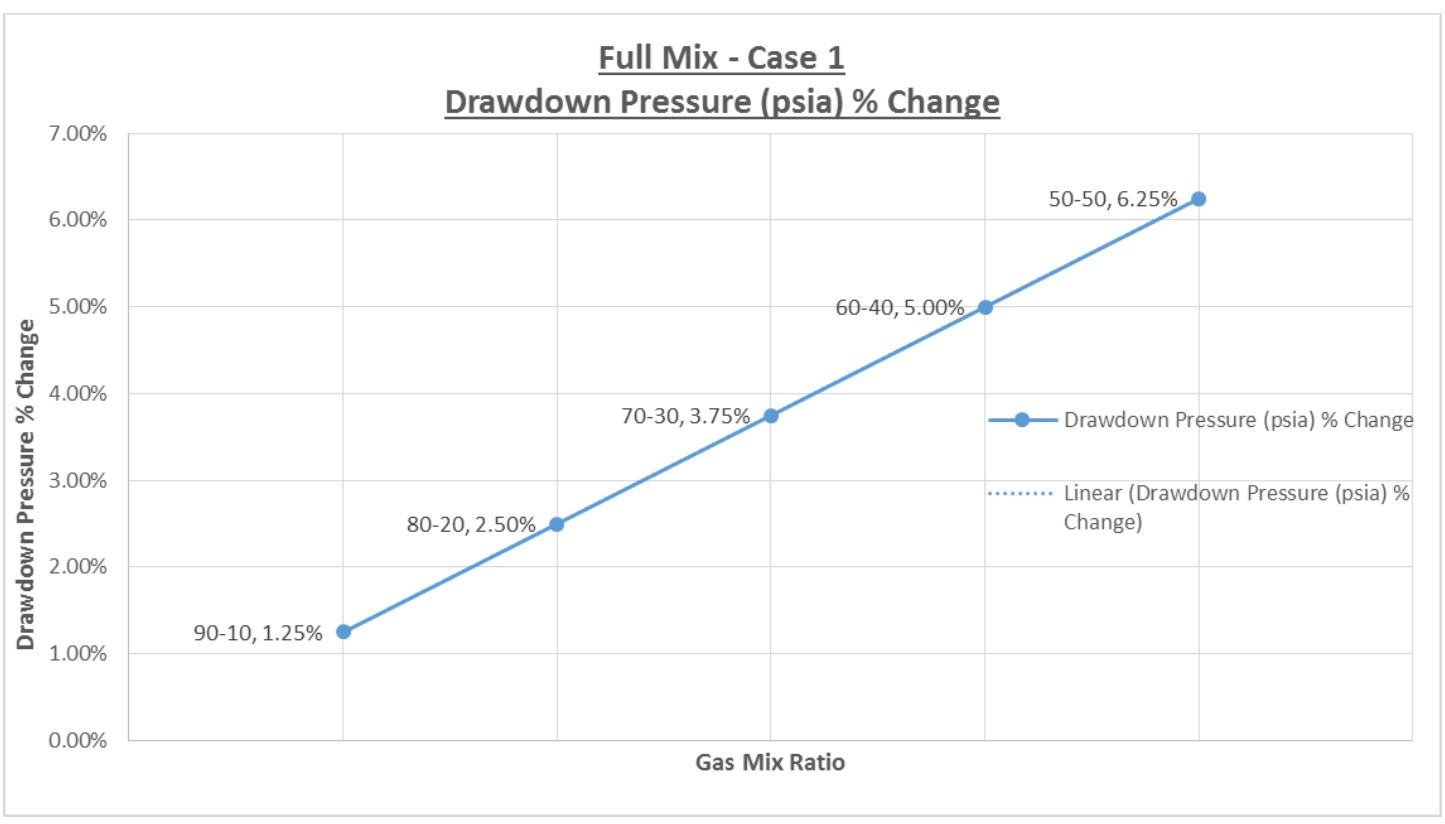

Figure 20 - Case 1: Full Mix - Drawdown \% Change - Intermediate Size and Pressure Reservoir 


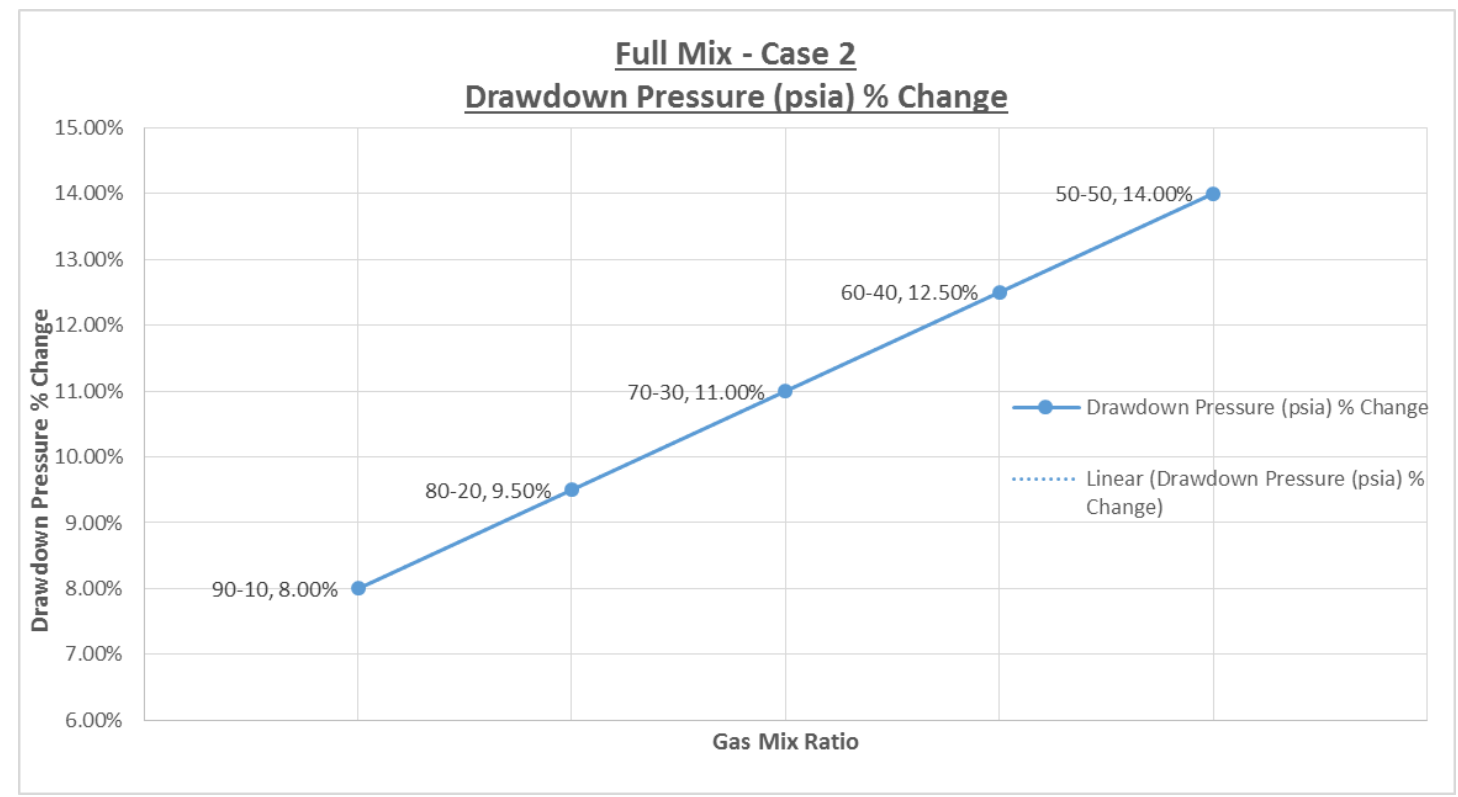

Figure 21 - Case 2: Full Mix - Drawdown \% Change - Small High-Pressure Reservoir

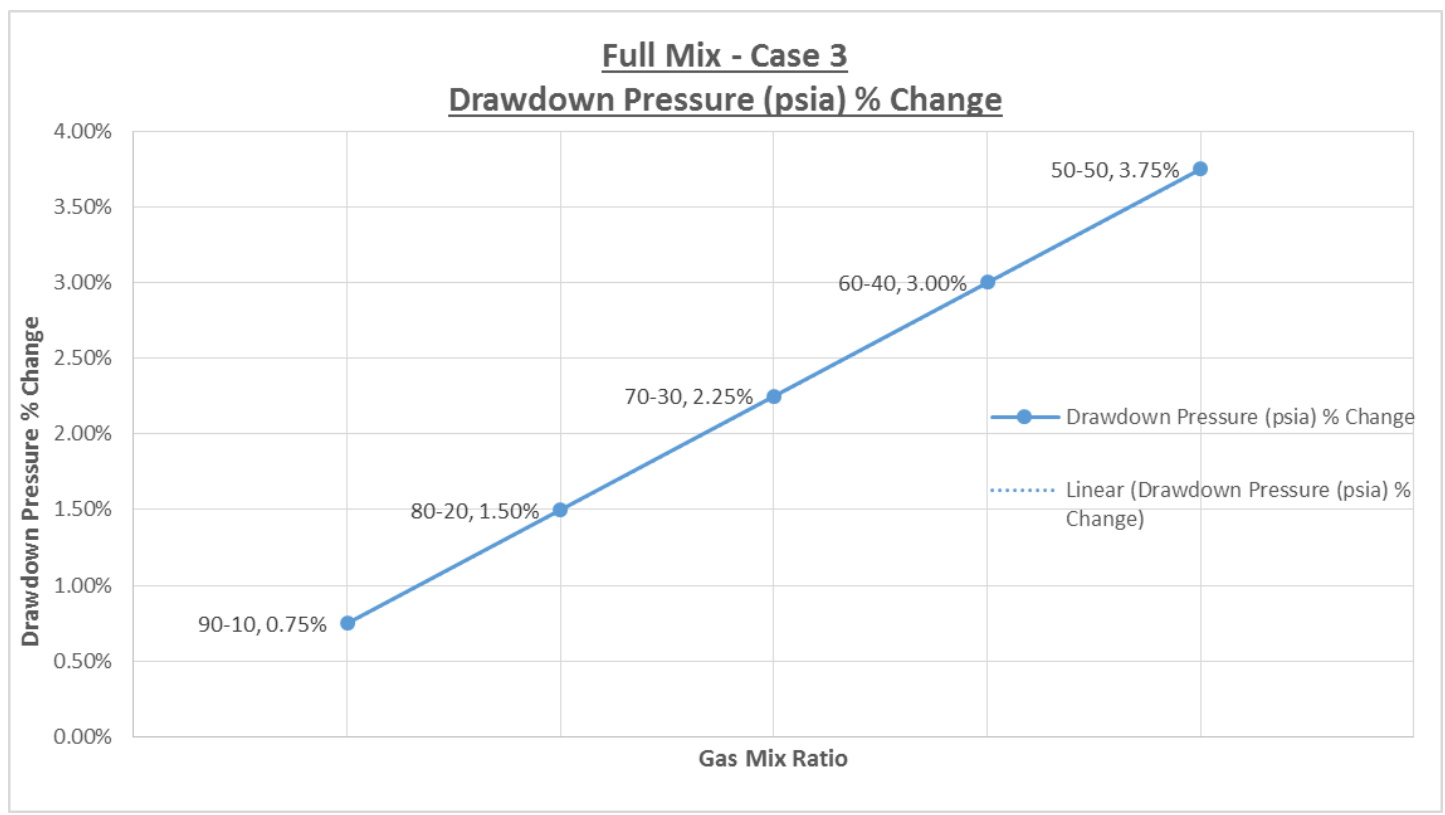

Figure 22 - Case 3: Full Mix - Drawdown \% Change - Large Low-Pressure Reservoir 


\subsection{Drawdown: No Mix}

The calculated gas drawdown required to achieve original flow rate (based on 400 psi drawdown using base gas composition) at the top storage pressure for reservoir cases 1, 2, and 3 are summarized in tables 30, 31, and 32. The percentage change in drawdown compared to the original drawdown (400 psi) are also listed in each table.

Table 30 - Case 1: No Mixing - Drawdown \% Change - Intermediate Size and Pressure Reservoir

\begin{tabular}{|c|c|c|c|}
\hline \multicolumn{4}{|c|}{ Case 1: No Mixing - Drawdown \% Change } \\
\hline $\begin{array}{c}\text { Mix Ratio } \\
\text { (Base:Working) }\end{array}$ & $\begin{array}{c}\text { Initial Drawdown } \\
\text { (psia) }\end{array}$ & $\begin{array}{c}\text { New Drawdown } \\
\text { (psia) }\end{array}$ & \% Change \\
\hline $90-10$ & 400.00 & 405.00 & $1.25 \%$ \\
\hline $80-20$ & 400.00 & 410.50 & $2.63 \%$ \\
\hline $70-30$ & 400.00 & 416.00 & $4.00 \%$ \\
\hline $60-40$ & 400.00 & 420.50 & $5.13 \%$ \\
\hline $50-50$ & 400.00 & 425.50 & $6.38 \%$ \\
\hline
\end{tabular}

Table 31 - Case 2: No Mixing - Drawdown \% Change - Small High-Pressure Reservoir

\begin{tabular}{|c|c|c|c|}
\hline \multicolumn{4}{|c|}{ Case 2: No Mixing - Drawdown \% Change } \\
\hline $\begin{array}{c}\text { Mix Ratio } \\
\text { (Base:Working) }\end{array}$ & $\begin{array}{c}\text { Initial Drawdown } \\
\text { (psia) }\end{array}$ & $\begin{array}{c}\text { New Drawdown } \\
\text { (psia) }\end{array}$ & \% Change \\
\hline $90-10$ & 400.00 & 431.50 & $7.88 \%$ \\
\hline $80-20$ & 400.00 & 439.00 & $9.75 \%$ \\
\hline $70-30$ & 400.00 & 444.00 & $11.00 \%$ \\
\hline $60-40$ & 400.00 & 450.00 & $12.50 \%$ \\
\hline $50-50$ & 400.00 & 456.00 & $14.00 \%$ \\
\hline
\end{tabular}

Table 32 - Case 3: No Mixing - Drawdown \% Change - Large Low-Pressure Reservoir

\begin{tabular}{|c|c|c|c|}
\hline \multicolumn{4}{|c|}{ Case 3: No Mixing - Drawdown \% Change } \\
\hline $\begin{array}{c}\text { Mix Ratio } \\
\text { (Base:Working) }\end{array}$ & $\begin{array}{c}\text { Initial Drawdown } \\
\text { (psia) }\end{array}$ & $\begin{array}{c}\text { New Drawdown } \\
\text { (psia) }\end{array}$ & \% Change \\
\hline $90-10$ & 400.00 & 403.00 & $0.75 \%$ \\
\hline $80-20$ & 400.00 & 406.00 & $1.50 \%$ \\
\hline $70-30$ & 400.00 & 409.00 & $2.25 \%$ \\
\hline $60-40$ & 400.00 & 413.00 & $3.25 \%$ \\
\hline $50-50$ & 400.00 & 416.00 & $4.00 \%$ \\
\hline
\end{tabular}


For all following cases, as the ratio of shale gas to the original gas in the mixture (working gas) was increased, the percentage change in drawdown compared to original drawdown increased. The percent change increased linearly for every case as illustrated in Figures 23, 24 and 25.

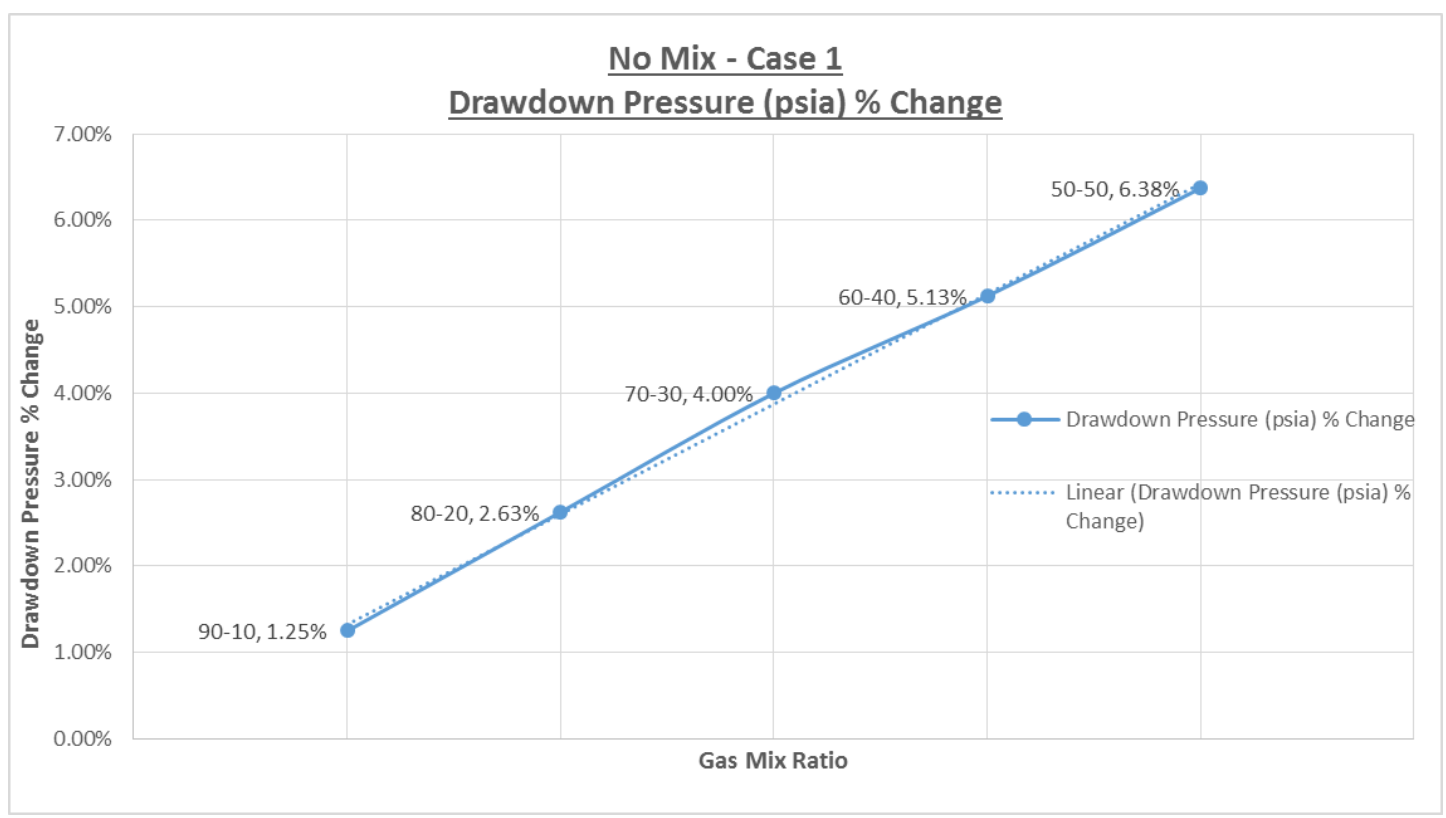

Figure 23 - Case 1: No Mixing - Drawdown \% Change - Intermediate Size and Pressure Reservoir

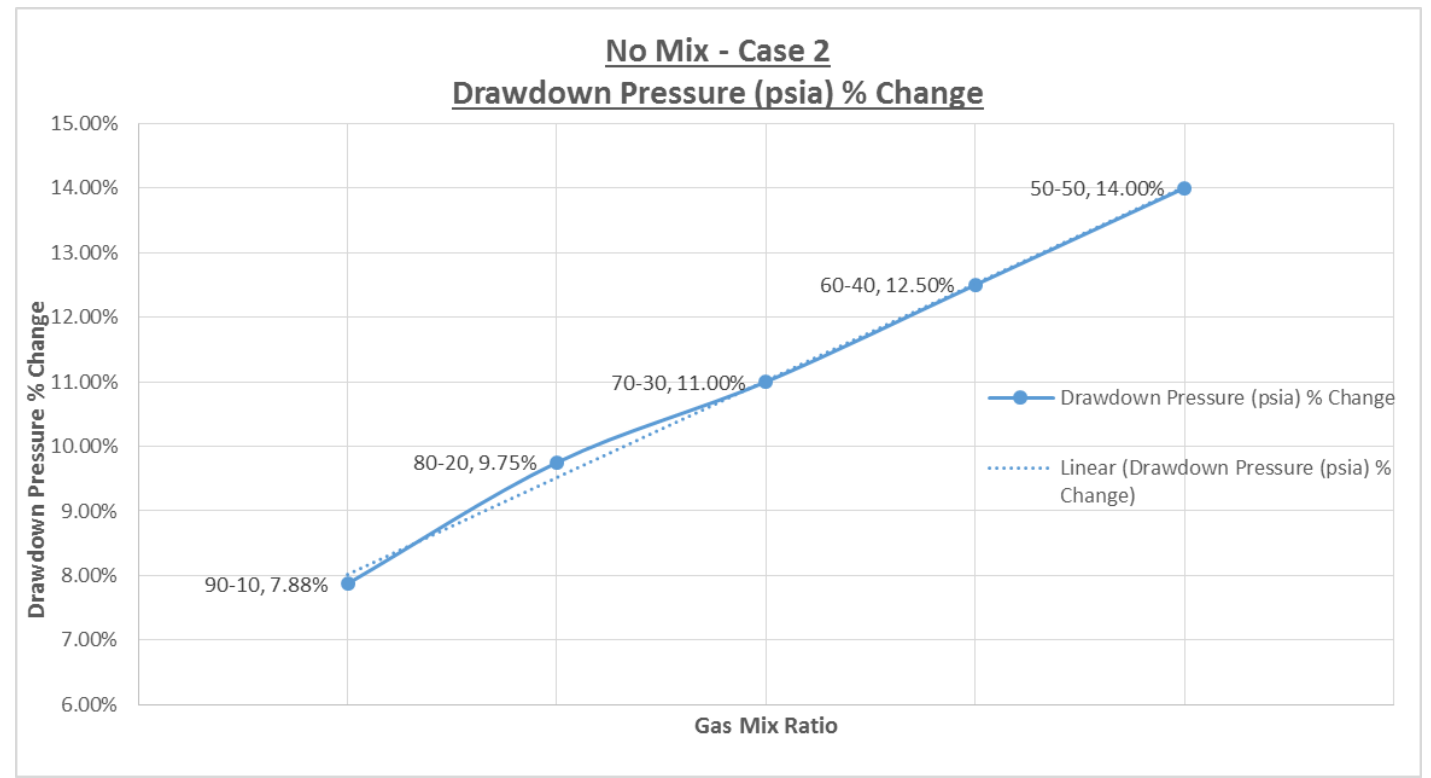

Figure 24 - Case 2: No Mixing - Drawdown \% Change - Small High-Pressure Reservoir 


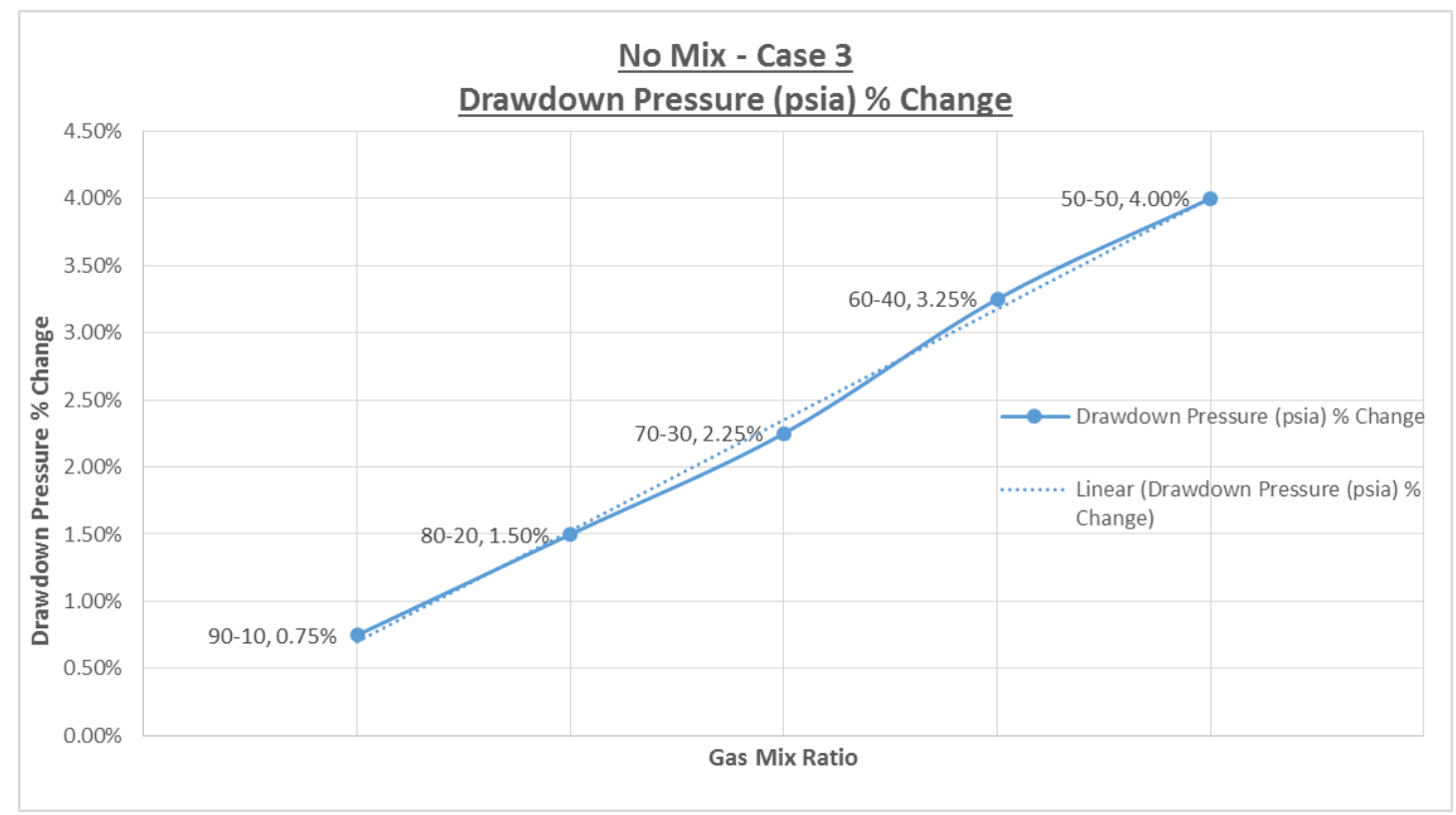

Figure 25 - Case 3: No Mixing-Drawdown \% Change - Large Low-Pressure Reservoir 


\section{Conclusions}

The following conclusions were reached for all the storage reservoir cases in this study:

1. The volume required to fill the pore volume of the reservoir increased as the percentage of the shale gas in the working gas was increased for both full mixing and no mixing cases.

2. The percent change in the volume was found to change linearly with the percentage of the shale gas in the working gas.

3. The top pressure in the reservoir after injecting a gas volume the same as the original working gas volume decreased as the percentage of shale gas in the working gas was increased for both full mixing and no mixing cases.

4. The percent change in top storage pressure was found to change linearly with the percentage of the shale gas in the working gas.

5. The gas withdrawal rate for a drawdown of $400 \mathrm{psi}$ decreased as the percentage of shale gas in the working gas increased for both full mixing and no mixing cases.

6. The percent change in gas withdrawal rate was found to change linearly with the percentage of the shale gas in the working gas.

7. The drawdown required to achieve original reservoir flow rate at top pressure increased as the percentage of shale gas in the working gas increased for both full mixing and no mixing cases.

8. The percent change in gas withdrawal rate was found to change linearly with the percentage of the shale gas in the working gas.

\section{Bibliography}

Aminian, K. (2015). Underground Storage Fundamentals. Morgantown, West Virginia: West Virginia University.

Ayers, K. L., Aminian, K., \& Ameri, S. (2012). The Impact of Multistage Fracturing on the Production Performance of the Horizontal Wells in Shale Formations. SPE-161347-PP. Lexington: Society of Petroleum Engineers.

Bullin, K., \& Krouskop, P. (2008). Composition Variety Complicates Processing Plans for US Shale Gas. Houston: Gas Processors Association.

Dietert, J. A., \& Pursell, D. A. (2000). Underground Natural Gas Storage. Houston: Simmons \& Company International.

Elsaig, M., Aminian, K., Ameri, S., \& Zamirian, M. (2016). Accurate Evaluation of Marcellus Shale Petrophysical Properties. SPE-184042-MS. Society of Petroleum Engineers. 
Garcia-Hernandez, A., Alvarado, A., \& Ridens, B. (2015). Impact of Gas Composition on Pipeline and Compressor Operating Conditions. PSIG 1523. New Orleans: Pipeline Simulation Interest Group.

NatGas. (2014). Natural Gas - From Wellhead to Burner Tip. Retrieved from NaturalGas.org: http://www.naturalgas.org/naturalgas/storage

Stokes, A. M., \& Summers, M. D. (2012). Advances in Optical Techniques for Moisture and Hydrocarbon Detection. Michell Instruments. 


\section{Appendix}

Appendix A - Shale Gas and Storage Gas Compositions and properties

Table 33 - Typical Marcellus Shale Gas (Working Gas) Composition

\begin{tabular}{|c|c|c|c|c|c|c|c|c|}
\hline Component & Mole Fraction & Corrected Mole Frac. & $T_{C},{ }^{o} R$ & $y \times T C$ & $P_{c, p s i a}$ & $y \times P C$ & $M$ & $y \times M$ \\
\hline $\mathrm{CO}_{2}$ & 0.001 & 0.00100 & 547.7 & 0.5477 & 1073.0 & 1.073 & 44.01 & 0.04401 \\
\hline$N_{2}$ & 0.003 & 0.00300 & 227.0 & 0.6810 & 493.0 & 1.479 & 28.01 & 0.08 \\
\hline $\mathrm{H}_{2} \mathrm{~S}$ & 0.000 & 0.00000 & 672.0 & 0.0000 & 1306.0 & 0 & 34.08 & 0.00 \\
\hline $\mathrm{CH}_{4}$ & 0.760 & 0.76000 & 343.3 & 260.9080 & 673.1 & 511.556 & 16.04 & 12.1904 \\
\hline $\mathrm{C}_{2} \mathrm{H}_{6}$ & 0.150 & 0.15000 & 549.8 & 82.4700 & 708.3 & 106.245 & 30.07 & 4.51 \\
\hline $\mathrm{C}_{3} \mathrm{H}_{8}$ & 0.059 & 0.05900 & 666.0 & 39.2940 & 617.4 & 36.4266 & 44.10 & 2.60 \\
\hline$i-\mathrm{C}_{4} \mathrm{H}_{10}$ & 0.007 & 0.00700 & 734.7 & 5.1429 & 529.1 & 3.7037 & 58.12 & 0.41 \\
\hline$n-C_{4} H_{10}$ & 0.007 & 0.00700 & 765.3 & 5.3571 & 550.7 & 3.8549 & 58.12 & 0.41 \\
\hline$i-C_{5} H_{12}$ & 0.004 & 0.00400 & 829.8 & 3.3192 & 483.0 & 1.932 & 72.15 & 0.22 \\
\hline$n-C_{5} H_{12}$ & 0.003 & 0.00300 & 845.6 & 2.5368 & 489.5 & 1.4685 & 72.15 & 0.14 \\
\hline $\mathrm{C}_{6} \mathrm{H}_{14}$ & 0.002 & 0.00200 & 914.0 & 1.8280 & 439.7 & 0.8794 & 86.18 & 0.17 \\
\hline \multirow[t]{2}{*}{$C_{7}+$} & 0.004 & 0.00400 & 1098.1 & 4.3925 & 428.8 & 1.71533 & 120.00 & 0.5 \\
\hline & 1.00000 & 1.00000 & & 406.48 & & 670.33 & & 21.2576 \\
\hline
\end{tabular}

Table 34 - Typical Marcellus Storage Gas Composition

\begin{tabular}{|c|c|c|c|c|c|c|c|c|}
\hline Component & Mole Fraction & Corrected Mole Frac. & $T_{C},{ }^{o} R$ & $y \times T C$ & $P_{c}, p s i a$ & $y \times P C$ & $M$ & $y \times M$ \\
\hline $\mathrm{CO}_{2}$ & 0.001 & 0.00100 & 547.7 & 0.5477 & 1073.0 & 1.073 & 44.01 & 0.04401 \\
\hline $\mathrm{N}_{2}$ & 0.002 & 0.00200 & 227.0 & 0.4540 & 493.0 & 0.986 & 28.01 & 0.06 \\
\hline $\mathrm{H}_{2} \mathrm{~S}$ & 0.000 & 0.00000 & 672.0 & 0.0000 & 1306.0 & 0 & 34.08 & 0.00 \\
\hline $\mathrm{CH}_{4}$ & 0.980 & 0.98000 & 343.3 & 336.4340 & 673.1 & 659.638 & 16.04 & 15.7192 \\
\hline $\mathrm{C}_{2} \mathrm{H}_{6}$ & 0.010 & 0.01000 & 549.8 & 5.4980 & 708.3 & 7.083 & 30.07 & 0.30 \\
\hline $\mathrm{C}_{3} \mathrm{H}_{8}$ & 0.003 & 0.00300 & 666.0 & 1.9980 & 617.4 & 1.8522 & 44.10 & 0.13 \\
\hline$i-C_{4} H_{10}$ & 0.002 & 0.00200 & 734.7 & 1.4694 & 529.1 & 1.0582 & 58.12 & 0.12 \\
\hline$n-C_{4} H_{10}$ & 0.0008 & 0.00080 & 765.3 & 0.6122 & 550.7 & 0.44056 & 58.12 & 0.05 \\
\hline$i-C_{5} H_{12}$ & 0.0004 & 0.00040 & 829.8 & 0.3319 & 483.0 & 0.1932 & 72.15 & 0.02 \\
\hline$n-C_{5} H_{12}$ & 0.0003 & 0.00030 & 845.6 & 0.2537 & 489.5 & 0.14685 & 72.15 & 0.01 \\
\hline $\mathrm{C}_{6} \mathrm{H}_{14}$ & 0.0002 & 0.00020 & 914.0 & 0.1828 & 439.7 & 0.08794 & 86.18 & 0.02 \\
\hline \multirow[t]{2}{*}{$c_{7}+$} & 0.0003 & 0.00030 & 1098.1 & 0.3294 & 428.8 & 0.12865 & 120.00 & 0.0 \\
\hline & 1.00000 & 1.00000 & & 348.11 & & 672.69 & & 16.5043 \\
\hline
\end{tabular}


Table 35 - Compositions of Storage Gas and Shale Gas Mixtures

\begin{tabular}{|c|c|c|c|c|c|c|c|}
\hline & Storage & Shale & \multicolumn{5}{|c|}{ Mix } \\
\hline Component & Mole Fraction & Mole Fraction & $90-10$ & $80-20$ & $70-30$ & $60-40$ & $50-50$ \\
\hline $\mathrm{CO}_{2}$ & 0.001 & 0.001 & 0.001 & 0.001 & 0.001 & 0.001 & 0.001 \\
\hline$N_{2}$ & 0.002 & 0.003 & 0.0021 & 0.0022 & 0.0023 & 0.0024 & 0.0025 \\
\hline $\mathrm{H}_{2} \mathrm{~S}$ & 0.000 & 0.000 & 0 & 0 & 0 & 0 & 0 \\
\hline $\mathrm{CH}_{4}$ & 0.980 & 0.760 & 0.958 & 0.936 & 0.914 & 0.892 & 0.870 \\
\hline $\mathrm{C}_{2} \mathrm{H}_{6}$ & 0.010 & 0.150 & 0.024 & 0.038 & 0.052 & 0.066 & 0.080 \\
\hline $\mathrm{C}_{3} \mathrm{H}_{8}$ & 0.003 & 0.059 & 0.0086 & 0.0142 & 0.0198 & 0.0254 & 0.031 \\
\hline$i-\mathrm{C}_{4} \mathrm{H}_{10}$ & 0.002 & 0.007 & 0.0025 & 0.003 & 0.0035 & 0.004 & 0.0045 \\
\hline$n-\mathrm{C}_{4} \mathrm{H}_{10}$ & 0.0008 & 0.007 & 0.00142 & 0.00204 & 0.00266 & 0.00328 & 0.0039 \\
\hline$i-\mathrm{C}_{5} \mathrm{H}_{12}$ & 0.0004 & 0.004 & 0.00076 & 0.00112 & 0.00148 & 0.00184 & 0.0022 \\
\hline$n-\mathrm{C}_{5} \mathrm{H}_{12}$ & 0.0003 & 0.003 & 0.00057 & 0.00084 & 0.00111 & 0.00138 & 0.00165 \\
\hline $\mathrm{C}_{6} \mathrm{H}_{14}$ & 0.0002 & 0.002 & 0.00038 & 0.00056 & 0.00074 & 0.00092 & 0.0011 \\
\hline $\mathrm{C}_{7}+$ & 0.0003 & 0.004 & 0.00067 & 0.00104 & 0.00141 & 0.00178 & 0.00215 \\
\hline Total & 1.0000 & 1.0000 & 1.0000 & 1.0000 & 1.0000 & 1.0000 & 1.0000 \\
\hline
\end{tabular}


Appendix B - Case 1 Storage Reservoir: Full Mix Data

Table 36 - Case 1: Shale Gas 90-10 Full Mix Ratio Composition

\begin{tabular}{|c|c|c|c|}
\hline \multicolumn{1}{c|}{} & $90-10$ Working Gas & Storage & Mix \\
\hline Component & Mole Fraction & Mole Fraction & Mole Fraction \\
\hline $\mathrm{CO}_{2}$ & 0.001 & 0.001 & 0.001 \\
\hline $\mathrm{N}_{2}$ & 0.0021 & 0.002 & 0.002055 \\
\hline $\mathrm{H}_{2} \mathrm{~S}$ & 0 & 0.000 & 0 \\
\hline $\mathrm{CH}_{4}$ & 0.958 & 0.980 & 0.9679 \\
\hline $\boldsymbol{C}_{2} \boldsymbol{H}_{6}$ & 0.024 & 0.010 & 0.0177 \\
\hline $\boldsymbol{C}_{3} \boldsymbol{H}_{8}$ & 0.0086 & 0.003 & 0.00608 \\
\hline$i-C_{4} H_{10}$ & 0.0025 & 0.002 & 0.002275 \\
\hline$n-C_{4} H_{10}$ & 0.00142 & 0.0008 & 0.001141 \\
\hline$i-C_{5} H_{12}$ & 0.00076 & 0.0004 & 0.000598 \\
\hline$n-C_{5} H_{12}$ & 0.00057 & 0.0003 & 0.0004485 \\
\hline$C_{6} H_{14}$ & 0.00038 & 0.0002 & 0.000299 \\
\hline$C_{7}+$ & 0.00067 & 0.0003 & 0.0005035 \\
\hline & 1.00000 & 1.00000 & 1.00000 \\
\hline
\end{tabular}

Table 37 - Case 1 Storage Reservoir: 90-10 Full Mix Composition

\begin{tabular}{|c|c|c|c|c|c|c|c|c|}
\hline Component & Mole Fraction & Corrected Mole Frac. & $T_{c},{ }^{o} R$ & $y \times T_{c}$ & $P_{c}, p s i a$ & $y \times P_{c}$ & $M$ & $y \times M$ \\
\hline $\mathrm{CO}_{2}$ & 0.001 & 0.00100 & 547.7 & 0.5477 & 1073.0 & 1.073 & 44.01 & 0.04401 \\
\hline$N_{2}$ & 0.002055 & 0.00206 & 227.0 & 0.4665 & 493.0 & 1.01312 & 28.01 & 0.06 \\
\hline $\mathrm{H}_{2} \mathrm{~S}$ & 0 & 0.00000 & 672.0 & 0.0000 & 1306.0 & 0 & 34.08 & 0.00 \\
\hline $\mathrm{CH}_{4}$ & 0.9679 & 0.96790 & 343.3 & 332.2801 & 673.1 & 651.493 & 16.04 & 15.5251 \\
\hline $\mathrm{C}_{2} \mathrm{H}_{6}$ & 0.0177 & 0.01770 & 549.8 & 9.7315 & 708.3 & 12.5369 & 30.07 & 0.53 \\
\hline $\mathrm{C}_{3} \mathrm{H}_{8}$ & 0.00608 & 0.00608 & 666.0 & 4.0493 & 617.4 & 3.75379 & 44.10 & 0.27 \\
\hline$i-C_{4} H_{10}$ & 0.002275 & 0.00228 & 734.7 & 1.6714 & 529.1 & 1.2037 & 58.12 & 0.13 \\
\hline$n-C_{4} H_{10}$ & 0.001141 & 0.00114 & 765.3 & 0.8732 & 550.7 & 0.62835 & 58.12 & 0.07 \\
\hline$i-C_{5} H_{12}$ & 0.000598 & 0.00060 & 829.8 & 0.4962 & 483.0 & 0.28883 & 72.15 & 0.03 \\
\hline$n-C_{5} H_{12}$ & 0.0004485 & 0.00045 & 845.6 & 0.3793 & 489.5 & 0.21954 & 72.15 & 0.02 \\
\hline $\mathrm{C}_{6} \mathrm{H}_{14}$ & 0.000299 & 0.00030 & 914.0 & 0.2733 & 439.7 & 0.13147 & 86.18 & 0.03 \\
\hline \multirow[t]{2}{*}{$c_{7}+$} & 0.0005035 & 0.00050 & 1098.1 & 0.5529 & 428.8 & 0.21592 & 120.00 & 0.1 \\
\hline & 1.00000 & 1.00000 & & 351.32 & & 672.56 & & 16.7657 \\
\hline
\end{tabular}


Table 38 - Case 1: Shale Gas 80-20 Full Mix Ratio Composition

\begin{tabular}{|c|c|c|c|}
\hline & $80-20$ Working Gas & Storage & Mix \\
\hline Component & Mole Fraction & Mole Fraction & Mole Fraction \\
\hline $\mathrm{CO}_{2}$ & 0.001 & 0.001 & 0.001 \\
\hline $\mathrm{N}_{2}$ & 0.0022 & 0.002 & 0.00211 \\
\hline $\mathrm{H}_{2} \mathrm{~S}$ & 0 & 0.000 & 0 \\
\hline $\mathrm{CH}_{4}$ & 0.936 & 0.980 & 0.9558 \\
\hline $\mathrm{C}_{2} \mathrm{H}_{6}$ & 0.038 & 0.010 & 0.0254 \\
\hline $\mathrm{C}_{3} \mathrm{H}_{8}$ & 0.0142 & 0.003 & 0.00916 \\
\hline$i-\mathrm{C}_{4} \mathrm{H}_{10}$ & 0.003 & 0.002 & 0.00255 \\
\hline$n-\mathrm{C}_{4} \mathrm{H}_{10}$ & 0.00204 & 0.0008 & 0.001482 \\
\hline$i-\mathrm{C}_{5} \boldsymbol{H}_{12}$ & 0.00112 & 0.0004 & 0.000796 \\
\hline$n-\mathrm{C}_{5} \mathrm{H}_{12}$ & 0.00084 & 0.0003 & 0.000597 \\
\hline $\mathrm{C}_{6} \mathrm{H}_{14}$ & 0.00056 & 0.0002 & 0.000398 \\
\hline $\mathrm{C}_{7}+$ & 0.00104 & 0.0003 & 0.000707 \\
\hline & 1.00000 & 1.00000 & 1.00000 \\
\hline
\end{tabular}

Table 39 - Case 1 Storage Reservoir: 80-20 Full Mix Composition

\begin{tabular}{|c|c|c|c|c|c|c|c|c|}
\hline Component & Mole Fraction & Corrected Mole Frac. & $T_{c},{ }^{o} R$ & $y \times T_{c}$ & $P_{c}, p s i a$ & $y \times P_{c}$ & $M$ & $y \times M$ \\
\hline $\mathrm{CO}_{2}$ & 0.001 & 0.00100 & 547.7 & 0.5477 & 1073.0 & 1.073 & 44.01 & 0.04401 \\
\hline$N_{2}$ & 0.00211 & 0.00211 & 227.0 & 0.4790 & 493.0 & 1.04023 & 28.01 & 0.06 \\
\hline $\mathrm{H}_{2} \mathrm{~S}$ & 0 & 0.00000 & 672.0 & 0.0000 & 1306.0 & 0 & 34.08 & 0.00 \\
\hline $\mathrm{CH}_{4}$ & 0.9558 & 0.95580 & 343.3 & 328.1261 & 673.1 & 643.349 & 16.04 & 15.331 \\
\hline $\mathrm{C}_{2} \mathrm{H}_{6}$ & 0.0254 & 0.02540 & 549.8 & 13.9649 & 708.3 & 17.9908 & 30.07 & 0.76 \\
\hline $\mathrm{C}_{3} \mathrm{H}_{8}$ & 0.00916 & 0.00916 & 666.0 & 6.1006 & 617.4 & 5.65538 & 44.10 & 0.40 \\
\hline$i-C_{4} H_{10}$ & 0.00255 & 0.00255 & 734.7 & 1.8735 & 529.1 & 1.34921 & 58.12 & 0.15 \\
\hline$n-C_{4} H_{10}$ & 0.001482 & 0.00148 & 765.3 & 1.1342 & 550.7 & 0.81614 & 58.12 & 0.09 \\
\hline$i-C_{5} H_{12}$ & 0.000796 & 0.00080 & 829.8 & 0.6605 & 483.0 & 0.38447 & 72.15 & 0.04 \\
\hline$n-C_{5} H_{12}$ & 0.000597 & 0.00060 & 845.6 & 0.5048 & 489.5 & 0.29223 & 72.15 & 0.03 \\
\hline $\mathrm{C}_{6} \mathrm{H}_{14}$ & 0.000398 & 0.00040 & 914.0 & 0.3638 & 439.7 & 0.175 & 86.18 & 0.03 \\
\hline \multirow[t]{2}{*}{$c_{7}+$} & 0.000707 & 0.00071 & 1098.1 & 0.7764 & 428.8 & 0.30319 & 120.00 & 0.1 \\
\hline & 1.00000 & 1.00000 & & 354.53 & & 672.43 & & 17.0271 \\
\hline
\end{tabular}


Table 40 - Case 1: Shale Gas 70-30 Full Mix Ratio Composition

\begin{tabular}{|c|c|c|c|}
\hline & 70-30 Working Gas & Storage & Mix \\
\hline Component & Mole Fraction & Mole Fraction & Mole Fraction \\
\hline $\mathrm{CO}_{2}$ & 0.001 & 0.001 & 0.001 \\
\hline $\mathrm{N}_{2}$ & 0.0023 & 0.002 & 0.002165 \\
\hline $\mathrm{H}_{2} \mathrm{~S}$ & 0 & 0.000 & 0 \\
\hline $\mathrm{CH}_{4}$ & 0.914 & 0.980 & 0.9437 \\
\hline $\mathrm{C}_{2} \mathrm{H}_{6}$ & 0.052 & 0.010 & 0.0331 \\
\hline $\mathrm{C}_{3} \mathrm{H}_{8}$ & 0.0198 & 0.003 & 0.01224 \\
\hline$i-C_{4} H_{10}$ & 0.0035 & 0.002 & 0.002825 \\
\hline$n-C_{4} H_{10}$ & 0.00266 & 0.0008 & 0.001823 \\
\hline$i-C_{5} H_{12}$ & 0.00148 & 0.0004 & 0.000994 \\
\hline$n-C_{5} H_{12}$ & 0.00111 & 0.0003 & 0.0007455 \\
\hline $\mathrm{C}_{6} \mathrm{H}_{14}$ & 0.00074 & 0.0002 & 0.000497 \\
\hline \multirow[t]{2}{*}{$c_{7}+$} & 0.00141 & 0.0003 & 0.0009105 \\
\hline & 1.00000 & 1.00000 & 1.00000 \\
\hline
\end{tabular}

Table 41 - Case 1 Storage Reservoir: 70-30 Full Mix Composition

\begin{tabular}{|c|c|c|c|c|c|c|c|c|}
\hline Component & Mole Fraction & Corrected Mole Frac. & $T_{c},{ }^{o} R$ & $y \times T_{c}$ & $P_{c}, p s i a$ & $y \times P_{c}$ & $M$ & $y \times M$ \\
\hline $\mathrm{CO}_{2}$ & 0.001 & 0.00100 & 547.7 & 0.5477 & 1073.0 & 1.073 & 44.01 & 0.04401 \\
\hline$N_{2}$ & 0.002165 & 0.00217 & 227.0 & 0.4915 & 493.0 & 1.06735 & 28.01 & 0.06 \\
\hline $\mathrm{H}_{2} \mathrm{~S}$ & 0 & 0.00000 & 672.0 & 0.0000 & 1306.0 & 0 & 34.08 & 0.00 \\
\hline $\mathrm{CH}_{4}$ & 0.9437 & 0.94370 & 343.3 & 323.9722 & 673.1 & 635.204 & 16.04 & 15.1369 \\
\hline $\mathrm{C}_{2} \mathrm{H}_{6}$ & 0.0331 & 0.03310 & 549.8 & 18.1984 & 708.3 & 23.4447 & 30.07 & 1.00 \\
\hline $\mathrm{C}_{3} \mathrm{H}_{8}$ & 0.01224 & 0.01224 & 666.0 & 8.1518 & 617.4 & 7.55698 & 44.10 & 0.54 \\
\hline$i-C_{4} H_{10}$ & 0.002825 & 0.00283 & 734.7 & 2.0755 & 529.1 & 1.49471 & 58.12 & 0.16 \\
\hline$n-C_{4} H_{10}$ & 0.001823 & 0.00182 & 765.3 & 1.3951 & 550.7 & 1.00393 & 58.12 & 0.11 \\
\hline$i-C_{5} H_{12}$ & 0.000994 & 0.00099 & 829.8 & 0.8248 & 483.0 & 0.4801 & 72.15 & 0.05 \\
\hline$n-C_{5} H_{12}$ & 0.0007455 & 0.00075 & 845.6 & 0.6304 & 489.5 & 0.36492 & 72.15 & 0.04 \\
\hline $\mathrm{C}_{6} \mathrm{H}_{14}$ & 0.000497 & 0.00050 & 914.0 & 0.4543 & 439.7 & 0.21853 & 86.18 & 0.04 \\
\hline \multirow[t]{2}{*}{$C_{7}+$} & 0.0009105 & 0.00091 & 1098.1 & 0.9998 & 428.8 & 0.39045 & 120.00 & 0.1 \\
\hline & 1.00000 & 1.00000 & & 357.74 & & 672.30 & & 17.2886 \\
\hline
\end{tabular}


Table 42 - Case 1: Shale Gas 60-40 Full Mix Ratio Composition

\begin{tabular}{|c|c|c|c|}
\hline & 60-40 Working Gas & Storage & Mix \\
\hline Component & Mole Fraction & Mole Fraction & Mole Fraction \\
\hline $\mathrm{CO}_{2}$ & 0.001 & 0.001 & 0.001 \\
\hline $\mathrm{N}_{2}$ & 0.0024 & 0.002 & 0.00222 \\
\hline $\mathrm{H}_{2} \mathrm{~S}$ & 0 & 0.000 & 0 \\
\hline $\mathrm{CH}_{4}$ & 0.892 & 0.980 & 0.9316 \\
\hline $\mathrm{C}_{2} \mathrm{H}_{6}$ & 0.066 & 0.010 & 0.0408 \\
\hline $\mathrm{C}_{3} \mathrm{H}_{8}$ & 0.0254 & 0.003 & 0.01532 \\
\hline$i-C_{4} H_{10}$ & 0.004 & 0.002 & 0.0031 \\
\hline$n-C_{4} H_{10}$ & 0.00328 & 0.0008 & 0.002164 \\
\hline$i-C_{5} H_{12}$ & 0.00184 & 0.0004 & 0.001192 \\
\hline$n-C_{5} H_{12}$ & 0.00138 & 0.0003 & 0.000894 \\
\hline $\mathrm{C}_{6} \mathrm{H}_{14}$ & 0.00092 & 0.0002 & 0.000596 \\
\hline \multirow[t]{2}{*}{$c_{7}+$} & 0.00178 & 0.0003 & 0.001114 \\
\hline & 1.00000 & 1.00000 & 1.00000 \\
\hline
\end{tabular}

Table 43 - Case 1 Storage Reservoir: 60-40 Full Mix Composition

\begin{tabular}{|c|c|c|c|c|c|c|c|c|}
\hline Component & Mole Fraction & Corrected Mole Frac. & $T_{c},{ }^{o} R$ & $y \times T_{c}$ & $P_{c}, p s i a$ & $y \times P_{c}$ & $M$ & $y \times M$ \\
\hline $\mathrm{CO}_{2}$ & 0.001 & 0.00100 & 547.7 & 0.5477 & 1073.0 & 1.073 & 44.01 & 0.04401 \\
\hline $\mathrm{N}_{2}$ & 0.00222 & 0.00222 & 227.0 & 0.5039 & 493.0 & 1.09446 & 28.01 & 0.06 \\
\hline $\mathrm{H}_{2} \mathrm{~S}$ & 0 & 0.00000 & 672.0 & 0.0000 & 1306.0 & 0 & 34.08 & 0.00 \\
\hline $\mathrm{CH}_{4}$ & 0.9316 & 0.93160 & 343.3 & 319.8183 & 673.1 & 627.06 & 16.04 & 14.9429 \\
\hline $\mathrm{C}_{2} \mathrm{H}_{6}$ & 0.0408 & 0.04080 & 549.8 & 22.4318 & 708.3 & 28.8986 & 30.07 & 1.23 \\
\hline $\mathrm{C}_{3} \mathrm{H}_{8}$ & 0.01532 & 0.01532 & 666.0 & 10.2031 & 617.4 & 9.45857 & 44.10 & 0.68 \\
\hline$i-\mathrm{C}_{4} \mathrm{H}_{10}$ & 0.0031 & 0.00310 & 734.7 & 2.2776 & 529.1 & 1.64021 & 58.12 & 0.18 \\
\hline$n-C_{4} H_{10}$ & 0.002164 & 0.00216 & 765.3 & 1.6561 & 550.7 & 1.19171 & 58.12 & 0.13 \\
\hline$i-C_{5} H_{12}$ & 0.001192 & 0.00119 & 829.8 & 0.9891 & 483.0 & 0.57574 & 72.15 & 0.06 \\
\hline$n-C_{5} H_{12}$ & 0.000894 & 0.00089 & 845.6 & 0.7560 & 489.5 & 0.43761 & 72.15 & 0.04 \\
\hline $\mathrm{C}_{6} \mathrm{H}_{14}$ & 0.000596 & 0.00060 & 914.0 & 0.5447 & 439.7 & 0.26206 & 86.18 & 0.05 \\
\hline \multirow[t]{2}{*}{$C_{7}+$} & 0.001114 & 0.00111 & 1098.1 & 1.2233 & 428.8 & 0.47772 & 120.00 & 0.1 \\
\hline & 1.00000 & 1.00000 & & 360.95 & & 672.17 & & 17.55 \\
\hline
\end{tabular}


Table 44 - Case 1: Shale Gas 50-50 Full Mix Ratio Composition

\begin{tabular}{|c|c|c|c|}
\hline & 50-50 Working Gas & Storage & Mix \\
\hline Component & Mole Fraction & Mole Fraction & Mole Fraction \\
\hline $\mathrm{CO}_{2}$ & 0.001 & 0.001 & 0.001 \\
\hline $\mathrm{N}_{2}$ & 0.0025 & 0.002 & 0.002275 \\
\hline $\mathrm{H}_{2} \mathrm{~S}$ & 0 & 0.000 & 0 \\
\hline $\mathrm{CH}_{4}$ & 0.87 & 0.980 & 0.9195 \\
\hline $\mathrm{C}_{2} \mathrm{H}_{6}$ & 0.08 & 0.010 & 0.0485 \\
\hline $\mathrm{C}_{3} \mathrm{H}_{8}$ & 0.031 & 0.003 & 0.0184 \\
\hline$i-C_{4} H_{10}$ & 0.0045 & 0.002 & 0.003375 \\
\hline$n-C_{4} H_{10}$ & 0.0039 & 0.0008 & 0.002505 \\
\hline$i-C_{5} H_{12}$ & 0.0022 & 0.0004 & 0.00139 \\
\hline$n-C_{5} H_{12}$ & 0.00165 & 0.0003 & 0.0010425 \\
\hline $\mathrm{C}_{6} \mathrm{H}_{14}$ & 0.0011 & 0.0002 & 0.000695 \\
\hline \multirow[t]{2}{*}{$c_{7}+$} & 0.00215 & 0.0003 & 0.0013175 \\
\hline & 1.00000 & 1.00000 & 1.00000 \\
\hline
\end{tabular}

Table 45 - Case 1 Storage Reservoir: 50-50 Full Mix Composition

\begin{tabular}{|c|c|c|c|c|c|c|c|c|}
\hline Component & Mole Fraction & Corrected Mole Frac. & $T_{C},{ }^{o} R$ & $y \times T C$ & $P_{c}, p s i a$ & $y \times P C$ & $M$ & $y \times M$ \\
\hline $\mathrm{CO}_{2}$ & 0.001 & 0.00100 & 547.7 & 0.5477 & 1073.0 & 1.073 & 44.01 & 0.04401 \\
\hline $\mathrm{N}_{2}$ & 0.002275 & 0.00228 & 227.0 & 0.5164 & 493.0 & 1.12158 & 28.01 & 0.06 \\
\hline $\mathrm{H}_{2} \mathrm{~S}$ & 0 & 0.00000 & 672.0 & 0.0000 & 1306.0 & 0 & 34.08 & 0.00 \\
\hline $\mathrm{CH}_{4}$ & 0.920 & 0.91950 & 343.3 & 315.6644 & 673.1 & 618.915 & 16.04 & 14.7488 \\
\hline $\mathrm{C}_{2} \mathrm{H}_{6}$ & 0.049 & 0.04850 & 549.8 & 26.6653 & 708.3 & 34.3526 & 30.07 & 1.46 \\
\hline $\mathrm{C}_{3} \mathrm{H}_{8}$ & 0.0184 & 0.01840 & 666.0 & 12.2544 & 617.4 & 11.3602 & 44.10 & 0.81 \\
\hline$i-\mathrm{C}_{4} \mathrm{H}_{10}$ & 0.003375 & 0.00338 & 734.7 & 2.4796 & 529.1 & 1.78571 & 58.12 & 0.20 \\
\hline$n-C_{4} H_{10}$ & 0.002505 & 0.00251 & 765.3 & 1.9171 & 550.7 & 1.3795 & 58.12 & 0.15 \\
\hline$i-\mathrm{C}_{5} \mathrm{H}_{12}$ & 0.00139 & 0.00139 & 829.8 & 1.1534 & 483.0 & 0.67137 & 72.15 & 0.08 \\
\hline$n-C_{5} H_{12}$ & 0.0010425 & 0.00104 & 845.6 & 0.8815 & 489.5 & 0.5103 & 72.15 & 0.05 \\
\hline $\mathrm{C}_{6} \mathrm{H}_{14}$ & 0.000695 & 0.00070 & 914.0 & 0.6352 & 439.7 & 0.30559 & 86.18 & 0.06 \\
\hline \multirow[t]{2}{*}{$c_{7}+$} & 0.0013175 & 0.00132 & 1098.1 & 1.4468 & 428.8 & 0.56499 & 120.00 & 0.2 \\
\hline & 1.00000 & 1.00000 & & 364.16 & & 672.04 & & 17.8114 \\
\hline
\end{tabular}


Appendix C - Case 2 Storage Reservoir: Full Mix Data

Table 46 - Case 2: Shale Gas 90-10 Full Mix Ratio Composition

\begin{tabular}{|c|c|c|c|}
\hline & $90-10$ Working Gas & Storage & Mix 2 \\
\hline Component & Mole Fraction & Mole Fraction & Mole Fraction \\
\hline $\mathrm{CO}_{2}$ & 0.001 & 0.001 & 0.001 \\
\hline $\boldsymbol{N}_{2}$ & 0.0021 & 0.002 & 0.00205 \\
\hline $\mathrm{H}_{2} \mathrm{~S}$ & 0 & 0.000 & 0 \\
\hline $\mathrm{CH}_{4}$ & 0.958 & 0.980 & 0.969 \\
\hline $\boldsymbol{C}_{2} \boldsymbol{H}_{6}$ & 0.024 & 0.010 & 0.017 \\
\hline $\boldsymbol{C}_{3} \boldsymbol{H}_{8}$ & 0.0086 & 0.003 & 0.0058 \\
\hline$i-C_{4} H_{10}$ & 0.0025 & 0.002 & 0.00225 \\
\hline$n-C_{4} H_{10}$ & 0.00142 & 0.0008 & 0.00111 \\
\hline$i-C_{5} H_{12}$ & 0.00076 & 0.0004 & 0.00058 \\
\hline$n-C_{5} H_{12}$ & 0.00057 & 0.0003 & 0.000435 \\
\hline$C_{6} H_{14}$ & 0.00038 & 0.0002 & 0.00029 \\
\hline$C_{7}+$ & 0.00067 & 0.0003 & 0.000485 \\
\hline & 1.00000 & 1.00000 & 1.00000 \\
\hline
\end{tabular}

Table 47 - Case 2 Storage Reservoir: 90-10 Full Mix Composition

\begin{tabular}{|c|c|c|c|c|c|c|c|c|}
\hline Component & Mole Fraction & Corrected Mole Frac. & $T_{c},{ }^{o} R$ & $y \times T_{c}$ & $P_{c}, p s i a$ & $y \times P_{c}$ & $M$ & $y \times M$ \\
\hline $\mathrm{CO}_{2}$ & 0.001 & 0.00100 & 547.7 & 0.5477 & 1073.0 & 1.073 & 44.01 & 0.04401 \\
\hline $\mathrm{N}_{2}$ & 0.00205 & 0.00205 & 227.0 & 0.4654 & 493.0 & 1.01065 & 28.01 & 0.06 \\
\hline $\mathrm{H}_{2} \mathrm{~S}$ & 0 & 0.00000 & 672.0 & 0.0000 & 1306.0 & 0 & 34.08 & 0.00 \\
\hline $\mathrm{CH}_{4}$ & 0.969 & 0.96900 & 343.3 & 332.6577 & 673.1 & 652.234 & 16.04 & 15.5428 \\
\hline $\mathrm{C}_{2} \mathrm{H}_{6}$ & 0.017 & 0.01700 & 549.8 & 9.3466 & 708.3 & 12.0411 & 30.07 & 0.51 \\
\hline $\mathrm{C}_{3} \mathrm{H}_{8}$ & 0.0058 & 0.00580 & 666.0 & 3.8628 & 617.4 & 3.58092 & 44.10 & 0.26 \\
\hline$i-\mathrm{C}_{4} \mathrm{H}_{10}$ & 0.00225 & 0.00225 & 734.7 & 1.6531 & 529.1 & 1.19048 & 58.12 & 0.13 \\
\hline$n-C_{4} H_{10}$ & 0.00111 & 0.00111 & 765.3 & 0.8495 & 550.7 & 0.61128 & 58.12 & 0.06 \\
\hline$i-C_{5} H_{12}$ & 0.00058 & 0.00058 & 829.8 & 0.4813 & 483.0 & 0.28014 & 72.15 & 0.03 \\
\hline$n-C_{5} H_{12}$ & 0.000435 & 0.00044 & 845.6 & 0.3678 & 489.5 & 0.21293 & 72.15 & 0.02 \\
\hline $\mathrm{C}_{6} \mathrm{H}_{14}$ & 0.00029 & 0.00029 & 914.0 & 0.2651 & 439.7 & 0.12751 & 86.18 & 0.02 \\
\hline \multirow[t]{2}{*}{$C_{7}+$} & 0.000485 & 0.00049 & 1098.1 & 0.5326 & 428.8 & 0.20798 & 120.00 & 0.1 \\
\hline & 1.00000 & 1.00000 & & 351.03 & & 672.57 & & 16.7419 \\
\hline
\end{tabular}


Table 48 - Case 2: Shale Gas 80-20 Full Mix Ratio Composition

\begin{tabular}{|c|c|c|c|}
\hline & $80-20$ Working Gas & Storage & Mix 2 \\
\hline Component & Mole Fraction & Mole Fraction & Mole Fraction \\
\hline $\mathrm{CO}_{2}$ & 0.001 & 0.001 & 0.001 \\
\hline$N_{2}$ & 0.0022 & 0.002 & 0.0021 \\
\hline $\mathrm{H}_{2} \mathrm{~S}$ & 0 & 0.000 & 0 \\
\hline $\mathrm{CH}_{4}$ & 0.936 & 0.980 & 0.958 \\
\hline $\mathrm{C}_{2} \mathrm{H}_{6}$ & 0.038 & 0.010 & 0.024 \\
\hline $\mathrm{C}_{3} \mathrm{H}_{8}$ & 0.0142 & 0.003 & 0.0086 \\
\hline$i-\mathrm{C}_{4} H_{10}$ & 0.003 & 0.002 & 0.0025 \\
\hline$n-C_{4} H_{10}$ & 0.00204 & 0.0008 & 0.00142 \\
\hline$i-C_{5} H_{12}$ & 0.00112 & 0.0004 & 0.00076 \\
\hline$n-C_{5} H_{12}$ & 0.00084 & 0.0003 & 0.00057 \\
\hline$C_{6} H_{14}$ & 0.00056 & 0.0002 & 0.00038 \\
\hline$C_{7}+$ & 0.00104 & 0.0003 & 0.00067 \\
\hline & 1.00000 & 1.00000 & 1.00000 \\
\hline
\end{tabular}

Table 49 - Case 2 Storage Reservoir: 80-20 Full Mix Composition

\begin{tabular}{|c|c|c|c|c|c|c|c|c|}
\hline Component & Mole Fraction & Corrected Mole Frac. & $T_{c},{ }^{o} R$ & $y \times T_{c}$ & $P_{c}, p s i a$ & $\boldsymbol{y} \times \boldsymbol{P}_{c}$ & $M$ & $y \times M$ \\
\hline $\mathrm{CO}_{2}$ & 0.001 & 0.00100 & 547.7 & 0.5477 & 1073.0 & 1.073 & 44.01 & 0.04401 \\
\hline $\mathrm{N}_{2}$ & 0.0021 & 0.00210 & 227.0 & 0.4767 & 493.0 & 1.0353 & 28.01 & 0.06 \\
\hline $\mathrm{H}_{2} \mathrm{~S}$ & 0 & 0.00000 & 672.0 & 0.0000 & 1306.0 & 0 & 34.08 & 0.00 \\
\hline $\mathrm{CH}_{4}$ & 0.958 & 0.95800 & 343.3 & 328.8814 & 673.1 & 644.83 & 16.04 & 15.3663 \\
\hline $\mathrm{C}_{2} \mathrm{H}_{6}$ & 0.024 & 0.02400 & 549.8 & 13.1952 & 708.3 & 16.9992 & 30.07 & 0.72 \\
\hline $\mathrm{C}_{3} \mathrm{H}_{8}$ & 0.0086 & 0.00860 & 666.0 & 5.7276 & 617.4 & 5.30964 & 44.10 & 0.38 \\
\hline$i-C_{4} H_{10}$ & 0.0025 & 0.00250 & 734.7 & 1.8368 & 529.1 & 1.32275 & 58.12 & 0.15 \\
\hline$n-C_{4} H_{10}$ & 0.00142 & 0.00142 & 765.3 & 1.0867 & 550.7 & 0.78199 & 58.12 & 0.08 \\
\hline$i-\mathrm{C}_{5} \mathrm{H}_{12}$ & 0.00076 & 0.00076 & 829.8 & 0.6306 & 483.0 & 0.36708 & 72.15 & 0.04 \\
\hline$n-C_{5} H_{12}$ & 0.00057 & 0.00057 & 845.6 & 0.4820 & 489.5 & 0.27902 & 72.15 & 0.03 \\
\hline $\mathrm{C}_{6} \mathrm{H}_{14}$ & 0.00038 & 0.00038 & 914.0 & 0.3473 & 439.7 & 0.16709 & 86.18 & 0.03 \\
\hline \multirow[t]{2}{*}{$c_{7+}$} & 0.00067 & 0.00067 & 1098.1 & 0.7357 & 428.8 & 0.28732 & 120.00 & 0.1 \\
\hline & 1.00000 & 1.00000 & & 353.95 & & 672.45 & & 16.9796 \\
\hline
\end{tabular}


Table 50 - Case 2: Shale Gas 70-30 Full Mix Ratio Composition

\begin{tabular}{|c|c|c|c|}
\hline & 70-30 Working Gas & Storage & Mix 2 \\
\hline Component & Mole Fraction & Mole Fraction & Mole Fraction \\
\hline $\mathrm{CO}_{2}$ & 0.001 & 0.001 & 0.001 \\
\hline$N_{2}$ & 0.0023 & 0.002 & 0.00215 \\
\hline$H_{2} S$ & 0 & 0.000 & 0 \\
\hline $\mathrm{CH}_{4}$ & 0.914 & 0.980 & 0.947 \\
\hline $\mathrm{C}_{2} H_{6}$ & 0.052 & 0.010 & 0.031 \\
\hline $\mathrm{C}_{3} H_{8}$ & 0.0198 & 0.003 & 0.0114 \\
\hline$i-C_{4} H_{10}$ & 0.0035 & 0.002 & 0.00275 \\
\hline$n-C_{4} H_{10}$ & 0.00266 & 0.0008 & 0.00173 \\
\hline$i-C_{5} H_{12}$ & 0.00148 & 0.0004 & 0.00094 \\
\hline$n-C_{5} H_{12}$ & 0.00111 & 0.0003 & 0.000705 \\
\hline$C_{6} H_{14}$ & 0.00074 & 0.0002 & 0.00047 \\
\hline$C_{7}+$ & 0.00141 & 0.0003 & 0.000855 \\
\hline & 1.00000 & 1.00000 & 1.00000 \\
\hline
\end{tabular}

Table 51 - Case 2 Storage Reservoir: 70-30 Full Mix Composition

\begin{tabular}{|c|c|c|c|c|c|c|c|c|}
\hline Component & Mole Fraction & Corrected Mole Frac. & $T_{c},{ }^{o} R$ & $y \times T_{c}$ & $P_{c}$, psia & $\boldsymbol{y} \times \boldsymbol{P}_{c}$ & $M$ & $y \times M$ \\
\hline $\mathrm{CO}_{2}$ & 0.001 & 0.00100 & 547.7 & 0.5477 & 1073.0 & 1.073 & 44.01 & 0.04401 \\
\hline $\mathrm{N}_{2}$ & 0.00215 & 0.00215 & 227.0 & 0.4881 & 493.0 & 1.05995 & 28.01 & 0.06 \\
\hline $\mathrm{H}_{2} \mathrm{~S}$ & 0 & 0.00000 & 672.0 & 0.0000 & 1306.0 & 0 & 34.08 & 0.00 \\
\hline $\mathrm{CH}_{4}$ & 0.947 & 0.94700 & 343.3 & 325.1051 & 673.1 & 637.426 & 16.04 & 15.1899 \\
\hline $\mathrm{C}_{2} \mathrm{H}_{6}$ & 0.031 & 0.03100 & 549.8 & 17.0438 & 708.3 & 21.9573 & 30.07 & 0.93 \\
\hline $\mathrm{C}_{3} \mathrm{H}_{8}$ & 0.0114 & 0.01140 & 666.0 & 7.5924 & 617.4 & 7.03836 & 44.10 & 0.50 \\
\hline$i-C_{4} H_{10}$ & 0.00275 & 0.00275 & 734.7 & 2.0204 & 529.1 & 1.45503 & 58.12 & 0.16 \\
\hline$n-C_{4} H_{10}$ & 0.00173 & 0.00173 & 765.3 & 1.3240 & 550.7 & 0.95271 & 58.12 & 0.10 \\
\hline$i-\mathrm{C}_{5} \mathrm{H}_{12}$ & 0.00094 & 0.00094 & 829.8 & 0.7800 & 483.0 & 0.45402 & 72.15 & 0.05 \\
\hline$n-C_{5} H_{12}$ & 0.000705 & 0.00071 & 845.6 & 0.5961 & 489.5 & 0.3451 & 72.15 & 0.03 \\
\hline $\mathrm{C}_{6} \mathrm{H}_{14}$ & 0.00047 & 0.00047 & 914.0 & 0.4296 & 439.7 & 0.20666 & 86.18 & 0.04 \\
\hline \multirow[t]{2}{*}{$C_{7}+$} & 0.000855 & 0.00086 & 1098.1 & 0.9389 & 428.8 & 0.36665 & 120.00 & 0.1 \\
\hline & 1.00000 & 1.00000 & & 356.87 & & 672.33 & & 17.2173 \\
\hline
\end{tabular}


Table 52 - Case 2: Shale Gas 60-40 Full Mix Ratio Composition

\begin{tabular}{|c|c|c|c|}
\hline & $60-40$ Working Gas & Storage & Mix 2 \\
\hline Component & Mole Fraction & Mole Fraction & Mole Fraction \\
\hline $\mathrm{CO}_{2}$ & 0.001 & 0.001 & 0.001 \\
\hline $\mathrm{N}_{2}$ & 0.0024 & 0.002 & 0.0022 \\
\hline $\mathrm{H}_{2} \mathrm{~S}$ & 0 & 0.000 & 0 \\
\hline $\mathrm{CH}_{4}$ & 0.892 & 0.980 & 0.936 \\
\hline $\mathrm{C}_{2} \mathrm{H}_{6}$ & 0.066 & 0.010 & 0.038 \\
\hline $\mathrm{C}_{3} \mathrm{H}_{8}$ & 0.0254 & 0.003 & 0.0142 \\
\hline$i-\mathrm{C}_{4} \mathrm{H}_{10}$ & 0.004 & 0.002 & 0.003 \\
\hline$n-\mathrm{C}_{4} \mathrm{H}_{10}$ & 0.00328 & 0.0008 & 0.00204 \\
\hline$i-\mathrm{C}_{5} \mathrm{H}_{12}$ & 0.00184 & 0.0004 & 0.00112 \\
\hline$n-\mathrm{C}_{5} \mathrm{H}_{12}$ & 0.00138 & 0.0003 & 0.00084 \\
\hline $\mathrm{C}_{6} \mathrm{H}_{14}$ & 0.00092 & 0.0002 & 0.00056 \\
\hline $\mathrm{C}_{7}+$ & 0.00178 & 0.0003 & 0.00104 \\
\hline & 1.00000 & 1.00000 & 1.00000 \\
\hline
\end{tabular}

Table 53 - Case 2 Storage Reservoir: 60-40 Full Mix Composition

\begin{tabular}{|c|c|c|c|c|c|c|c|c|}
\hline Component & Mole Fraction & Corrected Mole Frac. & $T_{c},{ }^{o} R$ & $y \times T_{c}$ & $P_{c}, p s i a$ & $y \times P_{c}$ & $M$ & $y \times M$ \\
\hline $\mathrm{CO}_{2}$ & 0.001 & 0.00100 & 547.7 & 0.5477 & 1073.0 & 1.073 & 44.01 & 0.04401 \\
\hline $\mathrm{N}_{2}$ & 0.0022 & 0.00220 & 227.0 & 0.4994 & 493.0 & 1.0846 & 28.01 & 0.06 \\
\hline $\mathrm{H}_{2} \mathrm{~S}$ & 0 & 0.00000 & 672.0 & 0.0000 & 1306.0 & 0 & 34.08 & 0.00 \\
\hline $\mathrm{CH}_{4}$ & 0.936 & 0.93600 & 343.3 & 321.3288 & 673.1 & 630.022 & 16.04 & 15.0134 \\
\hline $\mathrm{C}_{2} \mathrm{H}_{6}$ & 0.038 & 0.03800 & 549.8 & 20.8924 & 708.3 & 26.9154 & 30.07 & 1.14 \\
\hline $\mathrm{C}_{3} \mathrm{H}_{8}$ & 0.0142 & 0.01420 & 666.0 & 9.4572 & 617.4 & 8.76708 & 44.10 & 0.63 \\
\hline$i-\mathrm{C}_{4} \mathrm{H}_{10}$ & 0.003 & 0.00300 & 734.7 & 2.2041 & 529.1 & 1.5873 & 58.12 & 0.17 \\
\hline$n-C_{4} H_{10}$ & 0.00204 & 0.00204 & 765.3 & 1.5612 & 550.7 & 1.12343 & 58.12 & 0.12 \\
\hline$i-C_{5} H_{12}$ & 0.00112 & 0.00112 & 829.8 & 0.9294 & 483.0 & 0.54096 & 72.15 & 0.06 \\
\hline$n-C_{5} H_{12}$ & 0.00084 & 0.00084 & 845.6 & 0.7103 & 489.5 & 0.41118 & 72.15 & 0.04 \\
\hline $\mathrm{C}_{6} \mathrm{H}_{14}$ & 0.00056 & 0.00056 & 914.0 & 0.5118 & 439.7 & 0.24623 & 86.18 & 0.05 \\
\hline \multirow[t]{2}{*}{$c_{7}+$} & 0.00104 & 0.00104 & 1098.1 & 1.1420 & 428.8 & 0.44599 & 120.00 & 0.1 \\
\hline & 1.00000 & 1.00000 & & 359.78 & & 672.22 & & 17.4549 \\
\hline
\end{tabular}


Table 54 - Case 2: Shale Gas 50-50 Full Mix Ratio Composition

\begin{tabular}{|c|c|c|c|}
\hline & 50-50 Working Gas & Storage & Mix 2 \\
\hline Component & Mole Fraction & Mole Fraction & Mole Fraction \\
\hline $\mathrm{CO}_{2}$ & 0.001 & 0.001 & 0.001 \\
\hline$N_{2}$ & 0.0025 & 0.002 & 0.00225 \\
\hline$H_{2} S$ & 0 & 0.000 & 0 \\
\hline $\mathrm{CH}_{4}$ & 0.87 & 0.980 & 0.925 \\
\hline $\mathrm{C}_{2} H_{6}$ & 0.08 & 0.010 & 0.045 \\
\hline $\mathrm{C}_{3} H_{8}$ & 0.031 & 0.003 & 0.017 \\
\hline$i-C_{4} H_{10}$ & 0.0045 & 0.002 & 0.00325 \\
\hline$n-C_{4} H_{10}$ & 0.0039 & 0.0008 & 0.00235 \\
\hline$i-C_{5} H_{12}$ & 0.0022 & 0.0004 & 0.0013 \\
\hline$n-C_{5} H_{12}$ & 0.00165 & 0.0003 & 0.000975 \\
\hline$C_{6} H_{14}$ & 0.0011 & 0.0002 & 0.00065 \\
\hline$C_{7}+$ & 0.00215 & 0.0003 & 0.001225 \\
\hline & 1.00000 & 1.00000 & 1.00000 \\
\hline
\end{tabular}

Table 55 - Case 2 Storage Reservoir: 50-50 Full Mix Composition

\begin{tabular}{|c|c|c|c|c|c|c|c|c|}
\hline Component & Mole Fraction & Corrected Mole Frac. & $T_{C},{ }^{o} R$ & $y \times T C$ & $P_{c}$, psia & $y \times P C$ & $M$ & $y \times M$ \\
\hline $\mathrm{CO}_{2}$ & 0.001 & 0.00100 & 547.7 & 0.5477 & 1073.0 & 1.073 & 44.01 & 0.04401 \\
\hline $\mathrm{N}_{2}$ & 0.00225 & 0.00225 & 227.0 & 0.5108 & 493.0 & 1.10925 & 28.01 & 0.06 \\
\hline $\mathrm{H}_{2} \mathrm{~S}$ & 0 & 0.00000 & 672.0 & 0.0000 & 1306.0 & 0 & 34.08 & 0.00 \\
\hline $\mathrm{CH}_{4}$ & 0.925 & 0.92500 & 343.3 & 317.5525 & 673.1 & 622.618 & 16.04 & 14.837 \\
\hline $\mathrm{C}_{2} \mathrm{H}_{6}$ & 0.045 & 0.04500 & 549.8 & 24.7410 & 708.3 & 31.8735 & 30.07 & 1.35 \\
\hline $\mathrm{C}_{3} \mathrm{H}_{8}$ & 0.017 & 0.01700 & 666.0 & 11.3220 & 617.4 & 10.4958 & 44.10 & 0.75 \\
\hline$i-C_{4} H_{10}$ & 0.00325 & 0.00325 & 734.7 & 2.3878 & 529.1 & 1.71958 & 58.12 & 0.19 \\
\hline$n-C_{4} H_{10}$ & 0.00235 & 0.00235 & 765.3 & 1.7985 & 550.7 & 1.29415 & 58.12 & 0.14 \\
\hline$i-\mathrm{C}_{5} \mathrm{H}_{12}$ & 0.0013 & 0.00130 & 829.8 & 1.0787 & 483.0 & 0.6279 & 72.15 & 0.07 \\
\hline$n-C_{5} H_{12}$ & 0.000975 & 0.00098 & 845.6 & 0.8245 & 489.5 & 0.47726 & 72.15 & 0.05 \\
\hline $\mathrm{C}_{6} \mathrm{H}_{14}$ & 0.00065 & 0.00065 & 914.0 & 0.5941 & 439.7 & 0.28581 & 86.18 & 0.06 \\
\hline \multirow[t]{2}{*}{$C_{7}+$} & 0.001225 & 0.00123 & 1098.1 & 1.3452 & 428.8 & 0.52532 & 120.00 & 0.1 \\
\hline & 1.00000 & 1.00000 & & 362.70 & & 672.10 & & 17.6926 \\
\hline
\end{tabular}


Appendix D - Case 3 Storage Reservoir: Full Mix Data

Table 56 - Case 3: Shale Gas 90-10 Full Mix Ratio Composition

\begin{tabular}{|c|c|c|c|}
\hline & $90-10$ Working Gas & Storage & Mix 2 \\
\hline Component & Mole Fraction & Mole Fraction & Mole Fraction \\
\hline $\mathrm{CO}_{2}$ & 0.001 & 0.001 & 0.001 \\
\hline $\mathrm{N}_{2}$ & 0.0021 & 0.002 & 0.002053125 \\
\hline $\mathrm{H}_{2} \mathrm{~S}$ & 0 & 0.000 & 0 \\
\hline $\mathrm{CH}_{4}$ & 0.958 & 0.980 & 0.9683125 \\
\hline $\mathrm{C}_{2} \mathrm{H}_{6}$ & 0.024 & 0.010 & 0.0174375 \\
\hline $\mathrm{C}_{3} \boldsymbol{H}_{8}$ & 0.0086 & 0.003 & 0.005975 \\
\hline$i-C_{4} H_{10}$ & 0.0025 & 0.002 & 0.002265625 \\
\hline$n-C_{4} H_{10}$ & 0.00142 & 0.0008 & 0.001129375 \\
\hline$i-C_{5} H_{12}$ & 0.00076 & 0.0004 & 0.00059125 \\
\hline$n-C_{5} H_{12}$ & 0.00057 & 0.0003 & 0.000443438 \\
\hline$C_{6} H_{14}$ & 0.00038 & 0.0002 & 0.000295625 \\
\hline$C_{7}+$ & 0.00067 & 0.0003 & 0.000496563 \\
\hline & 1.00000 & 1.00000 & 1.00000 \\
\hline
\end{tabular}

Table 57 - Case 3 Storage Reservoir: 90-10 Full Mix Composition

\begin{tabular}{|c|c|c|c|c|c|c|c|c|}
\hline Component & Mole Fraction & Corrected Mole Frac. & $T_{c},{ }^{o} R$ & $y \times T_{c}$ & $P_{c}, p s i a$ & $y \times P_{c}$ & $M$ & $y \times M$ \\
\hline $\mathrm{CO}_{2}$ & 0.001 & 0.00100 & 547.7 & 0.5477 & 1073.0 & 1.073 & 44.01 & 0.04401 \\
\hline $\mathrm{N}_{2}$ & 0.002053125 & 0.00205 & 227.0 & 0.4661 & 493.0 & 1.01219 & 28.01 & 0.06 \\
\hline $\mathrm{H}_{2} \mathrm{~S}$ & 0 & 0.00000 & 672.0 & 0.0000 & 1306.0 & 0 & 34.08 & 0.00 \\
\hline $\mathrm{CH}_{4}$ & 0.9683125 & 0.96831 & 343.3 & 332.4217 & 673.1 & 651.771 & 16.04 & 15.5317 \\
\hline $\mathrm{C}_{2} \mathrm{H}_{6}$ & 0.0174375 & 0.01744 & 549.8 & 9.5871 & 708.3 & 12.351 & 30.07 & 0.52 \\
\hline $\mathrm{C}_{3} \mathrm{H}_{8}$ & 0.005975 & 0.00598 & 666.0 & 3.9794 & 617.4 & 3.68897 & 44.10 & 0.26 \\
\hline$i-C_{4} H_{10}$ & 0.002265625 & 0.00227 & 734.7 & 1.6646 & 529.1 & 1.19874 & 58.12 & 0.13 \\
\hline$n-C_{4} H_{10}$ & 0.001129375 & 0.00113 & 765.3 & 0.8643 & 550.7 & 0.62195 & 58.12 & 0.07 \\
\hline$i-\mathrm{C}_{5} \mathrm{H}_{12}$ & 0.00059125 & 0.00059 & 829.8 & 0.4906 & 483.0 & 0.28557 & 72.15 & 0.03 \\
\hline$n-C_{5} H_{12}$ & 0.000443438 & 0.00044 & 845.6 & 0.3750 & 489.5 & 0.21706 & 72.15 & 0.02 \\
\hline $\mathrm{C}_{6} \mathrm{H}_{14}$ & 0.000295625 & 0.00030 & 914.0 & 0.2702 & 439.7 & 0.12999 & 86.18 & 0.03 \\
\hline \multirow[t]{2}{*}{$C_{7+}$} & 0.000496563 & 0.00050 & 1098.1 & 0.5453 & 428.8 & 0.21294 & 120.00 & 0.1 \\
\hline & 1.00000 & 1.00000 & & 351.21 & & 672.56 & & 16.7568 \\
\hline
\end{tabular}


Table 58 - Case 3: Shale Gas 80-20 Full Mix Ratio Composition

\begin{tabular}{|c|c|c|c|}
\hline & $80-20$ Working Gas & Storage & Mix 2 \\
\hline Component & Mole Fraction & Mole Fraction & Mole Fraction \\
\hline $\mathrm{CO}_{2}$ & 0.001 & 0.001 & 0.001 \\
\hline $\mathrm{N}_{2}$ & 0.0022 & 0.002 & 0.00210625 \\
\hline $\mathrm{H}_{2} \mathrm{~S}$ & 0 & 0.000 & 0 \\
\hline $\mathrm{CH}_{4}$ & 0.936 & 0.980 & 0.956625 \\
\hline $\mathrm{C}_{2} \mathrm{H}_{6}$ & 0.038 & 0.010 & 0.024875 \\
\hline $\mathrm{C}_{3} \mathrm{H}_{8}$ & 0.0142 & 0.003 & 0.00895 \\
\hline$i-\mathrm{C}_{4} \mathrm{H}_{10}$ & 0.003 & 0.002 & 0.00253125 \\
\hline$n-\mathrm{C}_{4} \mathrm{H}_{10}$ & 0.00204 & 0.0008 & 0.00145875 \\
\hline$i-\mathrm{C}_{5} \mathrm{H}_{12}$ & 0.00112 & 0.0004 & 0.0007825 \\
\hline$n-\mathrm{C}_{5} \mathrm{H}_{12}$ & 0.00084 & 0.0003 & 0.000586875 \\
\hline $\mathrm{C}_{6} \mathrm{H}_{14}$ & 0.00056 & 0.0002 & 0.00039125 \\
\hline $\mathrm{C}_{7}+$ & 0.00104 & 0.0003 & 0.000693125 \\
\hline & 1.00000 & 1.00000 & 1.00000 \\
\hline
\end{tabular}

Table 59 - Case 3 Storage Reservoir: 80-20 Full Mix Composition

\begin{tabular}{|c|c|c|c|c|c|c|c|c|}
\hline Component & Mole Fraction & Corrected Mole Frac. & $T_{c},{ }^{o} R$ & $y \times T_{c}$ & $P_{c}, p s i a$ & $y \times P_{c}$ & $M$ & $y \times M$ \\
\hline $\mathrm{CO}_{2}$ & 0.001 & 0.00100 & 547.7 & 0.5477 & 1073.0 & 1.073 & 44.01 & 0.04401 \\
\hline$N_{2}$ & 0.00210625 & 0.00211 & 227.0 & 0.4781 & 493.0 & 1.03838 & 28.01 & 0.06 \\
\hline $\mathrm{H}_{2} \mathrm{~S}$ & 0 & 0.00000 & 672.0 & 0.0000 & 1306.0 & 0 & 34.08 & 0.00 \\
\hline $\mathrm{CH}_{4}$ & 0.956625 & 0.95663 & 343.3 & 328.4094 & 673.1 & 643.904 & 16.04 & 15.3443 \\
\hline $\mathrm{C}_{2} \mathrm{H}_{6}$ & 0.024875 & 0.02488 & 549.8 & 13.6763 & 708.3 & 17.619 & 30.07 & 0.75 \\
\hline $\mathrm{C}_{3} \mathrm{H}_{8}$ & 0.00895 & 0.00895 & 666.0 & 5.9607 & 617.4 & 5.52573 & 44.10 & 0.39 \\
\hline$i-\mathrm{C}_{4} \mathrm{H}_{10}$ & 0.00253125 & 0.00253 & 734.7 & 1.8597 & 529.1 & 1.33928 & 58.12 & 0.15 \\
\hline$n-C_{4} H_{10}$ & 0.00145875 & 0.00146 & 765.3 & 1.1164 & 550.7 & 0.80333 & 58.12 & 0.08 \\
\hline$i-C_{5} H_{12}$ & 0.0007825 & 0.00078 & 829.8 & 0.6493 & 483.0 & 0.37795 & 72.15 & 0.04 \\
\hline$n-C_{5} H_{12}$ & 0.000586875 & 0.00059 & 845.6 & 0.4963 & 489.5 & 0.28728 & 72.15 & 0.03 \\
\hline $\mathrm{C}_{6} \mathrm{H}_{14}$ & 0.00039125 & 0.00039 & 914.0 & 0.3576 & 439.7 & 0.17203 & 86.18 & 0.03 \\
\hline \multirow[t]{2}{*}{$c_{7+}$} & 0.000693125 & 0.00069 & 1098.1 & 0.7611 & 428.8 & 0.29724 & 120.00 & 0.1 \\
\hline & 1.00000 & 1.00000 & & 354.31 & & 672.44 & & 17.0093 \\
\hline
\end{tabular}


Table 60 - Case 3: Shale Gas 70-30 Full Mix Ratio Composition

\begin{tabular}{|c|c|c|c|}
\hline & 70-30 Working Gas & Storage & Mix 2 \\
\hline Component & Mole Fraction & Mole Fraction & Mole Fraction \\
\hline $\mathrm{CO}_{2}$ & 0.001 & 0.001 & 0.001 \\
\hline $\mathrm{N}_{2}$ & 0.0023 & 0.002 & 0.002159375 \\
\hline $\mathrm{H}_{2} \mathrm{~S}$ & 0 & 0.000 & 0 \\
\hline $\mathrm{CH}_{4}$ & 0.914 & 0.980 & 0.9449375 \\
\hline $\mathrm{C}_{2} \mathrm{H}_{6}$ & 0.052 & 0.010 & 0.0323125 \\
\hline $\mathrm{C}_{3} \mathrm{H}_{8}$ & 0.0198 & 0.003 & 0.011925 \\
\hline$i-C_{4} H_{10}$ & 0.0035 & 0.002 & 0.002796875 \\
\hline$n-C_{4} H_{10}$ & 0.00266 & 0.0008 & 0.001788125 \\
\hline$i-C_{5} H_{12}$ & 0.00148 & 0.0004 & 0.00097375 \\
\hline$n-C_{5} H_{12}$ & 0.00111 & 0.0003 & 0.000730313 \\
\hline $\mathrm{C}_{6} \mathrm{H}_{14}$ & 0.00074 & 0.0002 & 0.000486875 \\
\hline \multirow[t]{2}{*}{$C_{7}+$} & 0.00141 & 0.0003 & 0.000889688 \\
\hline & 1.00000 & 1.00000 & 1.00000 \\
\hline
\end{tabular}

Table 61 - Case 3 Storage Reservoir: 70-30 Full Mix Composition

\begin{tabular}{|c|c|c|c|c|c|c|c|c|}
\hline Component & Mole Fraction & Corrected Mole Frac. & $T_{c},{ }^{o} R$ & $y \times T_{c}$ & $P_{c}$, psia & $y \times P_{c}$ & $M$ & $y \times M$ \\
\hline $\mathrm{CO}_{2}$ & 0.001 & 0.00100 & 547.7 & 0.5477 & 1073.0 & 1.073 & 44.01 & 0.04401 \\
\hline $\mathrm{N}_{2}$ & 0.002159375 & 0.00216 & 227.0 & 0.4902 & 493.0 & 1.06457 & 28.01 & 0.06 \\
\hline $\mathrm{H}_{2} \mathrm{~S}$ & 0 & 0.00000 & 672.0 & 0.0000 & 1306.0 & 0 & 34.08 & 0.00 \\
\hline $\mathrm{CH}_{4}$ & 0.9449375 & 0.94494 & 343.3 & 324.3970 & 673.1 & 636.037 & 16.04 & 15.1568 \\
\hline $\mathrm{C}_{2} \mathrm{H}_{6}$ & 0.0323125 & 0.03231 & 549.8 & 17.7654 & 708.3 & 22.8869 & 30.07 & 0.97 \\
\hline $\mathrm{C}_{3} \mathrm{H}_{8}$ & 0.011925 & 0.01193 & 666.0 & 7.9421 & 617.4 & 7.3625 & 44.10 & 0.53 \\
\hline$i-C_{4} H_{10}$ & 0.002796875 & 0.00280 & 734.7 & 2.0549 & 529.1 & 1.47983 & 58.12 & 0.16 \\
\hline$n-C_{4} H_{10}$ & 0.001788125 & 0.00179 & 765.3 & 1.3685 & 550.7 & 0.98472 & 58.12 & 0.10 \\
\hline$i-C_{5} H_{12}$ & 0.00097375 & 0.00097 & 829.8 & 0.8080 & 483.0 & 0.47032 & 72.15 & 0.05 \\
\hline$n-C_{5} H_{12}$ & 0.000730313 & 0.00073 & 845.6 & 0.6176 & 489.5 & 0.35749 & 72.15 & 0.04 \\
\hline $\mathrm{C}_{6} \mathrm{H}_{14}$ & 0.000486875 & 0.00049 & 914.0 & 0.4450 & 439.7 & 0.21408 & 86.18 & 0.04 \\
\hline \multirow[t]{2}{*}{$c_{7}+$} & 0.000889688 & 0.00089 & 1098.1 & 0.9770 & 428.8 & 0.38153 & 120.00 & 0.1 \\
\hline & 1.00000 & 1.00000 & & 357.41 & & 672.31 & & 17.2618 \\
\hline
\end{tabular}


Table 62 - Case 3: Shale Gas 60-40 Full Mix Ratio Composition

\begin{tabular}{|c|c|c|c|}
\hline & $60-40$ Working Gas & Storage & Mix 2 \\
\hline Component & Mole Fraction & Mole Fraction & Mole Fraction \\
\hline $\mathrm{CO}_{2}$ & 0.001 & 0.001 & 0.001 \\
\hline $\mathrm{N}_{2}$ & 0.0024 & 0.002 & 0.0022125 \\
\hline $\mathrm{H}_{2} \mathrm{~S}$ & 0 & 0.000 & 0 \\
\hline $\mathrm{CH}_{4}$ & 0.892 & 0.980 & 0.93325 \\
\hline $\mathrm{C}_{2} \mathrm{H}_{6}$ & 0.066 & 0.010 & 0.03975 \\
\hline $\mathrm{C}_{3} \mathrm{H}_{8}$ & 0.0254 & 0.003 & 0.0149 \\
\hline$i-\mathrm{C}_{4} \mathrm{H}_{10}$ & 0.004 & 0.002 & 0.0030625 \\
\hline$n-\mathrm{C}_{4} \mathrm{H}_{10}$ & 0.00328 & 0.0008 & 0.0021175 \\
\hline$i-\mathrm{C}_{5} \mathrm{H}_{12}$ & 0.00184 & 0.0004 & 0.001165 \\
\hline$n-\mathrm{C}_{5} \mathrm{H}_{12}$ & 0.00138 & 0.0003 & 0.00087375 \\
\hline $\mathrm{C}_{6} \mathrm{H}_{14}$ & 0.00092 & 0.0002 & 0.0005825 \\
\hline $\mathrm{C}_{7}+$ & 0.00178 & 0.0003 & 0.00108625 \\
\hline & 1.00000 & 1.00000 & 1.00000 \\
\hline
\end{tabular}

Table 63 - Case 3 Storage Reservoir: 60-40 Full Mix Composition

\begin{tabular}{|c|c|c|c|c|c|c|c|c|}
\hline Component & Mole Fraction & Corrected Mole Frac. & $T_{c},{ }^{o} R$ & $y \times T_{c}$ & $P_{c}, p s i a$ & $y \times P_{c}$ & $M$ & $y \times M$ \\
\hline $\mathrm{CO}_{2}$ & 0.001 & 0.00100 & 547.7 & 0.5477 & 1073.0 & 1.073 & 44.01 & 0.04401 \\
\hline $\mathrm{N}_{2}$ & 0.0022125 & 0.00221 & 227.0 & 0.5022 & 493.0 & 1.09076 & 28.01 & 0.06 \\
\hline $\mathrm{H}_{2} \mathrm{~S}$ & 0 & 0.00000 & 672.0 & 0.0000 & 1306.0 & 0 & 34.08 & 0.00 \\
\hline $\mathrm{CH}_{4}$ & 0.93325 & 0.93325 & 343.3 & 320.3847 & 673.1 & 628.171 & 16.04 & 14.9693 \\
\hline $\mathrm{C}_{2} \mathrm{H}_{6}$ & 0.03975 & 0.03975 & 549.8 & 21.8546 & 708.3 & 28.1549 & 30.07 & 1.20 \\
\hline $\mathrm{C}_{3} \mathrm{H}_{8}$ & 0.0149 & 0.01490 & 666.0 & 9.9234 & 617.4 & 9.19926 & 44.10 & 0.66 \\
\hline$i-C_{4} H_{10}$ & 0.0030625 & 0.00306 & 734.7 & 2.2500 & 529.1 & 1.62037 & 58.12 & 0.18 \\
\hline$n-C_{4} H_{10}$ & 0.0021175 & 0.00212 & 765.3 & 1.6205 & 550.7 & 1.16611 & 58.12 & 0.12 \\
\hline$i-\mathrm{C}_{5} \mathrm{H}_{12}$ & 0.001165 & 0.00117 & 829.8 & 0.9667 & 483.0 & 0.5627 & 72.15 & 0.06 \\
\hline$n-C_{5} H_{12}$ & 0.00087375 & 0.00087 & 845.6 & 0.7388 & 489.5 & 0.4277 & 72.15 & 0.04 \\
\hline $\mathrm{C}_{6} \mathrm{H}_{14}$ & 0.0005825 & 0.00058 & 914.0 & 0.5324 & 439.7 & 0.25613 & 86.18 & 0.05 \\
\hline \multirow[t]{2}{*}{$C_{7}+$} & 0.00108625 & 0.00109 & 1098.1 & 1.1928 & 428.8 & 0.46582 & 120.00 & 0.1 \\
\hline & 1.00000 & 1.00000 & & 360.51 & & 672.19 & & 17.5144 \\
\hline
\end{tabular}


Table 64 - Case 3: Shale Gas 50-50 Full Mix Ratio Composition

\begin{tabular}{|c|c|c|c|}
\hline & 50-50 Working Gas & Storage & Mix 2 \\
\hline Component & Mole Fraction & Mole Fraction & Mole Fraction \\
\hline $\mathrm{CO}_{2}$ & 0.001 & 0.001 & 0.001 \\
\hline $\mathrm{N}_{2}$ & 0.0025 & 0.002 & 0.002265625 \\
\hline $\mathrm{H}_{2} \mathrm{~S}$ & 0 & 0.000 & 0 \\
\hline $\mathrm{CH}_{4}$ & 0.87 & 0.980 & 0.9215625 \\
\hline $\mathrm{C}_{2} \mathrm{H}_{6}$ & 0.08 & 0.010 & 0.0471875 \\
\hline $\mathrm{C}_{3} \mathrm{H}_{8}$ & 0.031 & 0.003 & 0.017875 \\
\hline$i-\mathrm{C}_{4} \mathrm{H}_{10}$ & 0.0045 & 0.002 & 0.003328125 \\
\hline$n-\mathrm{C}_{4} \boldsymbol{H}_{10}$ & 0.0039 & 0.0008 & 0.002446875 \\
\hline$i-\mathrm{C}_{5} \mathrm{H}_{12}$ & 0.0022 & 0.0004 & 0.00135625 \\
\hline$n-\mathrm{C}_{5} \mathrm{H}_{12}$ & 0.00165 & 0.0003 & 0.001017188 \\
\hline $\mathrm{C}_{6} \mathrm{H}_{14}$ & 0.0011 & 0.0002 & 0.000678125 \\
\hline $\mathrm{C}_{7}+$ & 0.00215 & 0.0003 & 0.001282813 \\
\hline & 1.00000 & 1.00000 & 1.00000 \\
\hline
\end{tabular}

Table 65 - Case 3 Storage Reservoir: 50-50 Full Mix Composition

\begin{tabular}{|c|c|c|c|c|c|c|c|c|}
\hline Component & Mole Fraction & Corrected Mole Frac. & $T_{C},{ }^{o} R$ & $y \times T C$ & $P_{c}, p s i a$ & $y \times P C$ & $M$ & $y \times M$ \\
\hline $\mathrm{CO}_{2}$ & 0.001 & 0.00100 & 547.7 & 0.5477 & 1073.0 & 1.073 & 44.01 & 0.04401 \\
\hline $\mathrm{N}_{2}$ & 0.002265625 & 0.00227 & 227.0 & 0.5143 & 493.0 & 1.11695 & 28.01 & 0.06 \\
\hline $\mathrm{H}_{2} \mathrm{~S}$ & 0 & 0.00000 & 672.0 & 0.0000 & 1306.0 & 0 & 34.08 & 0.00 \\
\hline $\mathrm{CH}_{4}$ & 0.922 & 0.92156 & 343.3 & 316.3724 & 673.1 & 620.304 & 16.04 & 14.7819 \\
\hline $\mathrm{C}_{2} \mathrm{H}_{6}$ & 0.047 & 0.04719 & 549.8 & 25.9437 & 708.3 & 33.4229 & 30.07 & 1.42 \\
\hline $\mathrm{C}_{3} \mathrm{H}_{8}$ & 0.017875 & 0.01788 & 666.0 & 11.9048 & 617.4 & 11.036 & 44.10 & 0.79 \\
\hline$i-\mathrm{C}_{4} \mathrm{H}_{10}$ & 0.003328125 & 0.00333 & 734.7 & 2.4452 & 529.1 & 1.76091 & 58.12 & 0.19 \\
\hline$n-C_{4} H_{10}$ & 0.002446875 & 0.00245 & 765.3 & 1.8726 & 550.7 & 1.34749 & 58.12 & 0.14 \\
\hline$i-\mathrm{C}_{5} \mathrm{H}_{12}$ & 0.00135625 & 0.00136 & 829.8 & 1.1254 & 483.0 & 0.65507 & 72.15 & 0.07 \\
\hline$n-C_{5} H_{12}$ & 0.001017188 & 0.00102 & 845.6 & 0.8601 & 489.5 & 0.49791 & 72.15 & 0.05 \\
\hline $\mathrm{C}_{6} \mathrm{H}_{14}$ & 0.000678125 & 0.00068 & 914.0 & 0.6198 & 439.7 & 0.29817 & 86.18 & 0.06 \\
\hline \multirow[t]{2}{*}{$c_{7+}$} & 0.001282813 & 0.00128 & 1098.1 & 1.4087 & 428.8 & 0.55011 & 120.00 & 0.2 \\
\hline & 1.00000 & 1.00000 & & 363.61 & & 672.06 & & 17.7669 \\
\hline
\end{tabular}


Appendix E - Storage Reservoir: No Mix Data (Cases 1, 2, \& 3)

Table 66 - Case 1 Storage Reservoir: 90-10 No Mix Composition

\begin{tabular}{|c|c|c|c|c|c|c|c|c|}
\hline Component & Mole Fraction & Corrected Mole Frac. & $T_{c},{ }^{o} R$ & $y \times T_{c}$ & $P_{c}, p s i a$ & $y \times P_{c}$ & $M$ & $y \times M$ \\
\hline $\mathrm{CO}_{2}$ & 0.001 & 0.00100 & 547.7 & 0.5477 & 1073.0 & 1.073 & 44.01 & 0.04401 \\
\hline $\mathrm{N}_{2}$ & 0.0021 & 0.00210 & 227.0 & 0.4767 & 493.0 & 1.0353 & 28.01 & 0.06 \\
\hline $\mathrm{H}_{2} \mathrm{~S}$ & 0 & 0.00000 & 672.0 & 0.0000 & 1306.0 & 0 & 34.08 & 0.00 \\
\hline $\mathrm{CH}_{4}$ & 0.958 & 0.95800 & 343.3 & 328.8814 & 673.1 & 644.83 & 16.04 & 15.3663 \\
\hline $\mathrm{C}_{2} \mathrm{H}_{6}$ & 0.024 & 0.02400 & 549.8 & 13.1952 & 708.3 & 16.9992 & 30.07 & 0.72 \\
\hline $\mathrm{C}_{3} \mathrm{H}_{8}$ & 0.0086 & 0.00860 & 666.0 & 5.7276 & 617.4 & 5.30964 & 44.10 & 0.38 \\
\hline$i-C_{4} H_{10}$ & 0.0025 & 0.00250 & 734.7 & 1.8368 & 529.1 & 1.32275 & 58.12 & 0.15 \\
\hline$n-C_{4} H_{10}$ & 0.00142 & 0.00142 & 765.3 & 1.0867 & 550.7 & 0.78199 & 58.12 & 0.08 \\
\hline$i-\mathrm{C}_{5} \mathrm{H}_{12}$ & 0.00076 & 0.00076 & 829.8 & 0.6306 & 483.0 & 0.36708 & 72.15 & 0.04 \\
\hline$n-C_{5} H_{12}$ & 0.00057 & 0.00057 & 845.6 & 0.4820 & 489.5 & 0.27902 & 72.15 & 0.03 \\
\hline $\mathrm{C}_{6} \mathrm{H}_{14}$ & 0.00038 & 0.00038 & 914.0 & 0.3473 & 439.7 & 0.16709 & 86.18 & 0.03 \\
\hline \multirow[t]{2}{*}{$c_{7}+$} & 0.00067 & 0.00067 & 1098.1 & 0.7357 & 428.8 & 0.28732 & 120.00 & 0.1 \\
\hline & 1.00000 & 1.00000 & & 353.95 & & 672.45 & & 16.9796 \\
\hline
\end{tabular}

Table 67 - Case 1 Storage Reservoir: 80-20 No Mix Composition

\begin{tabular}{|c|c|c|c|c|c|c|c|c|}
\hline Component & Mole Fraction & Corrected Mole Frac. & $T_{c},{ }^{o} R$ & $y \times T_{c}$ & $P_{c}, p s i a$ & $y \times P_{c}$ & $M$ & $y \times M$ \\
\hline $\mathrm{CO}_{2}$ & 0.001 & 0.00100 & 547.7 & 0.5477 & 1073.0 & 1.073 & 44.01 & 0.04401 \\
\hline$N_{2}$ & 0.0022 & 0.00220 & 227.0 & 0.4994 & 493.0 & 1.0846 & 28.01 & 0.06 \\
\hline $\mathrm{H}_{2} \mathrm{~S}$ & 0 & 0.00000 & 672.0 & 0.0000 & 1306.0 & 0 & 34.08 & 0.00 \\
\hline $\mathrm{CH}_{4}$ & 0.936 & 0.93600 & 343.3 & 321.3288 & 673.1 & 630.022 & 16.04 & 15.0134 \\
\hline $\mathrm{C}_{2} \mathrm{H}_{6}$ & 0.038 & 0.03800 & 549.8 & 20.8924 & 708.3 & 26.9154 & 30.07 & 1.14 \\
\hline $\mathrm{C}_{3} \mathrm{H}_{8}$ & 0.0142 & 0.01420 & 666.0 & 9.4572 & 617.4 & 8.76708 & 44.10 & 0.63 \\
\hline$i-C_{4} H_{10}$ & 0.003 & 0.00300 & 734.7 & 2.2041 & 529.1 & 1.5873 & 58.12 & 0.17 \\
\hline$n-C_{4} H_{10}$ & 0.00204 & 0.00204 & 765.3 & 1.5612 & 550.7 & 1.12343 & 58.12 & 0.12 \\
\hline$i-C_{5} H_{12}$ & 0.00112 & 0.00112 & 829.8 & 0.9294 & 483.0 & 0.54096 & 72.15 & 0.06 \\
\hline$n-C_{5} H_{12}$ & 0.00084 & 0.00084 & 845.6 & 0.7103 & 489.5 & 0.41118 & 72.15 & 0.04 \\
\hline $\mathrm{C}_{6} \mathrm{H}_{14}$ & 0.00056 & 0.00056 & 914.0 & 0.5118 & 439.7 & 0.24623 & 86.18 & 0.05 \\
\hline \multirow[t]{2}{*}{$C_{7}+$} & 0.00104 & 0.00104 & 1098.1 & 1.1420 & 428.8 & 0.44599 & 120.00 & 0.1 \\
\hline & 1.00000 & 1.00000 & & 359.78 & & 672.22 & & 17.4549 \\
\hline
\end{tabular}


Table 68 - Case 1 Storage Reservoir: 70-30 No Mix Composition

\begin{tabular}{|c|c|c|c|c|c|c|c|c|}
\hline Component & Mole Fraction & Corrected Mole Frac. & $T_{c},{ }^{o} R$ & $y \times T_{c}$ & $P_{c}, p s i a$ & $y \times P_{c}$ & $M$ & $y \times M$ \\
\hline $\mathrm{CO}_{2}$ & 0.001 & 0.00100 & 547.7 & 0.5477 & 1073.0 & 1.073 & 44.01 & 0.04401 \\
\hline$N_{2}$ & 0.0023 & 0.00230 & 227.0 & 0.5221 & 493.0 & 1.1339 & 28.01 & 0.06 \\
\hline $\mathrm{H}_{2} \mathrm{~S}$ & 0 & 0.00000 & 672.0 & 0.0000 & 1306.0 & 0 & 34.08 & 0.00 \\
\hline $\mathrm{CH}_{4}$ & 0.914 & 0.91400 & 343.3 & 313.7762 & 673.1 & 615.213 & 16.04 & 14.6606 \\
\hline $\mathrm{C}_{2} \mathrm{H}_{6}$ & 0.052 & 0.05200 & 549.8 & 28.5896 & 708.3 & 36.8316 & 30.07 & 1.56 \\
\hline $\mathrm{C}_{3} \mathrm{H}_{8}$ & 0.0198 & 0.01980 & 666.0 & 13.1868 & 617.4 & 12.2245 & 44.10 & 0.87 \\
\hline $\mathrm{i}-\mathrm{C}_{4} \mathrm{H}_{10}$ & 0.0035 & 0.00350 & 734.7 & 2.5715 & 529.1 & 1.85185 & 58.12 & 0.20 \\
\hline$n-\mathrm{C}_{4} \mathrm{H}_{10}$ & 0.00266 & 0.00266 & 765.3 & 2.0357 & 550.7 & \begin{tabular}{|l|}
1.46486 \\
\end{tabular} & 58.12 & 0.15 \\
\hline$i-C_{5} H_{12}$ & 0.00148 & 0.00148 & 829.8 & 1.2281 & 483.0 & 0.71484 & 72.15 & 0.08 \\
\hline$n-C_{5} H_{12}$ & 0.00111 & 0.00111 & 845.6 & 0.9386 & 489.5 & 0.54335 & 72.15 & 0.05 \\
\hline $\mathrm{C}_{6} \mathrm{H}_{14}$ & 0.00074 & 0.00074 & 914.0 & 0.6764 & 439.7 & 0.32538 & 86.18 & 0.06 \\
\hline \multirow[t]{2}{*}{$c_{7}+$} & 0.00141 & 0.00141 & 1098.1 & 1.5483 & 428.8 & 0.60466 & 120.00 & 0.2 \\
\hline & 1.00000 & 1.00000 & & 365.62 & & 671.98 & & 17.9303 \\
\hline
\end{tabular}

Table 69 - Case 1 Storage Reservoir: 60-40 No Mix Composition

\begin{tabular}{|c|c|c|c|c|c|c|c|c|}
\hline Component & Mole Fraction & Corrected Mole Frac. & $T_{c},{ }^{o} R$ & $y \times T_{c}$ & $P_{c}, p s i a$ & $y \times P_{c}$ & $M$ & $y \times M$ \\
\hline $\mathrm{CO}_{2}$ & 0.001 & 0.00100 & 547.7 & 0.5477 & 1073.0 & 1.073 & 44.01 & 0.04401 \\
\hline $\mathrm{N}_{2}$ & 0.0024 & 0.00240 & 227.0 & 0.5448 & 493.0 & 1.1832 & 28.01 & 0.07 \\
\hline $\mathrm{H}_{2} \mathrm{~S}$ & 0 & 0.00000 & 672.0 & 0.0000 & 1306.0 & 0 & 34.08 & 0.00 \\
\hline $\mathrm{CH}_{4}$ & 0.892 & 0.89200 & 343.3 & 306.2236 & 673.1 & 600.405 & 16.04 & 14.3077 \\
\hline $\mathrm{C}_{2} \mathrm{H}_{6}$ & 0.066 & 0.06600 & 549.8 & 36.2868 & 708.3 & 46.7478 & 30.07 & 1.98 \\
\hline $\mathrm{C}_{3} \mathrm{H}_{8}$ & 0.0254 & 0.02540 & 666.0 & 16.9164 & 617.4 & 15.682 & 44.10 & 1.12 \\
\hline$i-\mathrm{C}_{4} \mathrm{H}_{10}$ & 0.004 & 0.00400 & 734.7 & 2.9388 & 529.1 & 2.1164 & 58.12 & 0.23 \\
\hline$n-C_{4} H_{10}$ & 0.00328 & 0.00328 & 765.3 & 2.5102 & 550.7 & 1.8063 & 58.12 & 0.19 \\
\hline$i-\mathrm{C}_{5} \mathrm{H}_{12}$ & 0.00184 & 0.00184 & 829.8 & 1.5268 & 483.0 & 0.88872 & 72.15 & 0.10 \\
\hline$n-C_{5} H_{12}$ & 0.00138 & 0.00138 & 845.6 & 1.1669 & 489.5 & 0.67551 & 72.15 & 0.07 \\
\hline $\mathrm{C}_{6} \mathrm{H}_{14}$ & 0.00092 & 0.00092 & 914.0 & 0.8409 & 439.7 & 0.40452 & 86.18 & 0.08 \\
\hline \multirow[t]{2}{*}{$C_{7}+$} & 0.00178 & 0.00178 & 1098.1 & 1.9546 & 428.8 & 0.76332 & 120.00 & 0.2 \\
\hline & 1.00000 & 1.00000 & & 371.46 & & 671.75 & & 18.4056 \\
\hline
\end{tabular}


Table 70 - Case 1 Storage Reservoir: 50-50 No Mix Composition

\begin{tabular}{|c|c|c|c|c|c|c|c|c|}
\hline Component & Mole Fraction & Corrected Mole Frac. & $T_{C},{ }^{o} R$ & $y \times T C$ & $P_{c}, p s i a$ & $y \times P C$ & $M$ & $y \times M$ \\
\hline $\mathrm{CO}_{2}$ & 0.001 & 0.00100 & 547.7 & 0.5477 & 1073.0 & 1.073 & 44.01 & 0.04401 \\
\hline$N_{2}$ & 0.0025 & 0.00250 & 227.0 & 0.5675 & 493.0 & 1.2325 & 28.01 & 0.07 \\
\hline $\mathrm{H}_{2} \mathrm{~S}$ & 0 & 0.00000 & 672.0 & 0.0000 & 1306.0 & 0 & 34.08 & 0.00 \\
\hline $\mathrm{CH}_{4}$ & 0.870 & 0.87000 & 343.3 & 298.6710 & 673.1 & 585.597 & 16.04 & 13.9548 \\
\hline $\mathrm{C}_{2} \mathrm{H}_{6}$ & 0.080 & 0.08000 & 549.8 & 43.9840 & 708.3 & 56.664 & 30.07 & 2.41 \\
\hline $\mathrm{C}_{3} \mathrm{H}_{8}$ & 0.031 & 0.03100 & 666.0 & 20.6460 & 617.4 & 19.1394 & 44.10 & 1.37 \\
\hline$i-C_{4} H_{10}$ & 0.0045 & 0.00450 & 734.7 & 3.3062 & 529.1 & 2.38095 & 58.12 & 0.26 \\
\hline$n-C_{4} H_{10}$ & 0.0039 & 0.00390 & 765.3 & 2.9847 & 550.7 & 2.14773 & 58.12 & 0.23 \\
\hline$i-\mathrm{C}_{5} \mathrm{H}_{12}$ & 0.0022 & 0.00220 & 829.8 & 1.8256 & 483.0 & 1.0626 & 72.15 & 0.12 \\
\hline$n-C_{5} H_{12}$ & 0.00165 & 0.00165 & 845.6 & 1.3952 & 489.5 & 0.80768 & 72.15 & 0.08 \\
\hline $\mathrm{C}_{6} \mathrm{H}_{14}$ & 0.0011 & 0.00110 & 914.0 & 1.0054 & 439.7 & 0.48367 & 86.18 & 0.09 \\
\hline \multirow[t]{2}{*}{$C_{7}+$} & 0.00215 & 0.00215 & 1098.1 & 2.3609 & 428.8 & 0.92199 & 120.00 & 0.3 \\
\hline & 1.00000 & 1.00000 & & 377.29 & & 671.51 & & 18.881 \\
\hline
\end{tabular}


Appendix F - Viscosity Composition

Table 71 - Shale Gas Viscosity Composition

\begin{tabular}{|c|c|c|c|c|c|c|c|c|c|}
\hline Component & $y_{i}$ & $M_{i}$ & $T_{c}\left({ }^{\circ} R\right)$ & $P_{c}$ (psia) & $\mu_{i 1}, c p$ & $T c * y i$ & $P c * y i$ & $\mu_{i}{ }^{*} y_{i} * M_{i} \wedge^{0.5}$ & $y_{i}^{*} M_{i} \wedge^{0.5}$ \\
\hline $\mathrm{CO} 2$ & 0.001 & 44.01 & 548 & 1072 & 0.016 & 0.548 & 1.072 & 0.000106144 & 0.006634003 \\
\hline N2 & 0.003 & 28.01 & 227 & 492 & 0.019 & 0.681 & 1.476 & 0.00030167 & 0.015877342 \\
\hline$C 1$ & 0.760 & 16.04 & 344 & 673 & 0.012 & 261.44 & 511.48 & 0.036525572 & 3.043797628 \\
\hline$C 2$ & 0.150 & 30.07 & 550 & 709 & 0.0102 & 418 & 538.84 & 0.04250896 & 4.167545081 \\
\hline C3 & 0.059 & 44.1 & 666 & 618 & 0.009 & 99.9 & 92.7 & 0.008965057 & 0.996117463 \\
\hline$i-C 4$ & 0.007 & 58.12 & 733 & 530 & 0.0083 & 43.247 & 31.27 & 0.0037333 & 0.449795198 \\
\hline$n-C 4$ & 0.007 & 58.12 & 766 & 551 & 0.008 & 5.362 & 3.857 & 0.000426924 & 0.053365532 \\
\hline$i-C 5$ & 0.004 & 72.12 & 830 & 482 & 0.0072 & 5.81 & 3.374 & 0.000428014 & 0.059446446 \\
\hline$n-C 5$ & 0.003 & 72.15 & 847 & 485 & 0.007 & 3.388 & 1.94 & 0.000237835 & 0.033976462 \\
\hline C6 & 0.002 & 86.18 & 915 & 434 & 0.0066 & 2.745 & 1.302 & 0.00018381 & 0.027849955 \\
\hline$C 7+$ & 0.004 & 100.21 & 973 & 397 & 0.0062 & 1.946 & 0.794 & 0.00012413 & 0.020020989 \\
\hline Total & 1.000 & & & & & 843.067 & 1188.11 & 0.093541416 & 8.8744261 \\
\hline & 010540 & & & & & & & & \\
\hline$\mu_{g 1}$ & 01054056 & & & & & & & & \\
\hline
\end{tabular}

Table 72 - Storage Gas Viscosity Composition

\begin{tabular}{|c|c|c|c|c|c|c|c|c|c|}
\hline Component & $y_{i}$ & $M_{i}$ & $T_{c}\left({ }^{\circ} R\right)$ & $P_{c}(p s i a)$ & $\mu_{i 1}, c p$ & $T c * y i$ & $P c * y i$ & $\mu_{i}{ }^{*} y_{i} * M_{i} \wedge^{0.5}$ & $y_{i} * M_{i} \wedge^{0.5}$ \\
\hline $\mathrm{CO} 2$ & 0.001 & 44.01 & 548 & 1072 & 0.016 & 0.548 & 1.072 & 0.000106144 & 0.006634003 \\
\hline N2 & 0.002 & 28.01 & 227 & 492 & 0.019 & 0.454 & 0.984 & 0.000201113 & 0.010584895 \\
\hline$C 1$ & 0.980 & 16.04 & 344 & 673 & 0.012 & 337.12 & 659.54 & 0.047098763 & 3.924896941 \\
\hline$C 2$ & 0.010 & 30.07 & 550 & 709 & 0.0102 & 539 & 694.82 & 0.054814185 & 5.373939709 \\
\hline$C 3$ & 0.003 & 44.1 & 666 & 618 & 0.009 & 6.66 & 6.18 & 0.00059767 & 0.066407831 \\
\hline$i-C 4$ & 0.002 & 58.12 & 733 & 530 & 0.0083 & 2.199 & 1.59 & 0.000189829 & 0.022870942 \\
\hline$n-C 4$ & 0.0008 & 58.12 & 766 & 551 & 0.008 & 1.532 & 1.102 & 0.000121978 & 0.015247295 \\
\hline$i-C 5$ & 0.0004 & 72.12 & 830 & 482 & 0.0072 & 0.664 & 0.3856 & 4.89159E-05 & 0.00679388 \\
\hline$n-C 5$ & 0.0003 & 72.15 & 847 & 485 & 0.007 & 0.3388 & 0.194 & $2.37835 E-05$ & 0.003397646 \\
\hline C6 & 0.0002 & 86.18 & 915 & 434 & 0.0066 & 0.2745 & 0.1302 & $1.8381 E-05$ & 0.002784996 \\
\hline$C 7+$ & 0.0003 & 100.21 & 973 & 397 & 0.0062 & 0.1946 & 0.0794 & $1.2413 E-05$ & 0.002002099 \\
\hline Total & 1.000 & & & & & 888.985 & 1366.08 & 0.103233176 & 9.435560237 \\
\hline$\mu_{g 1}$ & 0.01094086 & & & & & & & & \\
\hline
\end{tabular}


Appendix G-Compressibility Factor (z-chart)

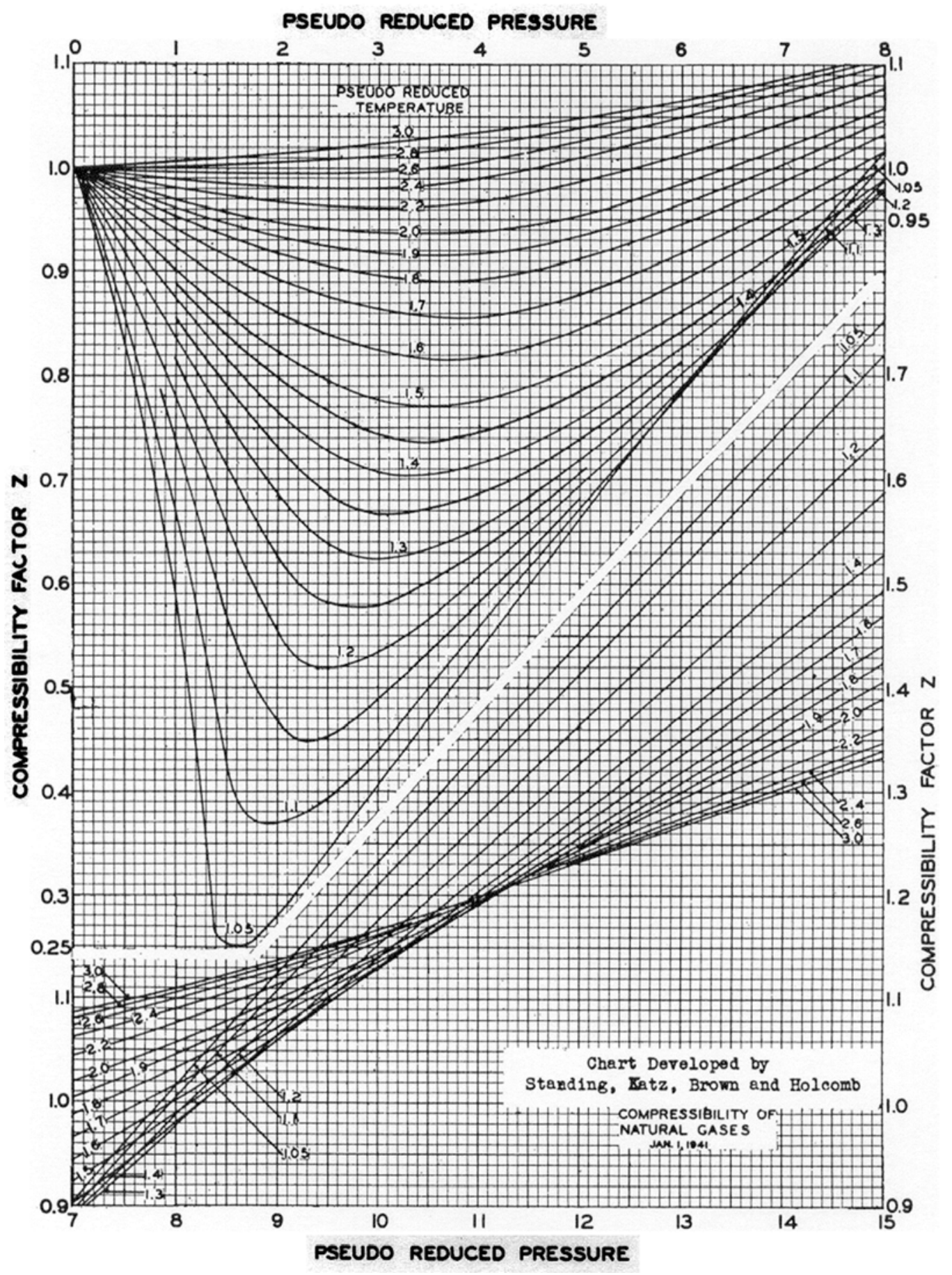

Figure 26 - Compressibility Factor (z-chart) 
Appendix $\mathrm{H}$ - Viscosity Ratio Chart

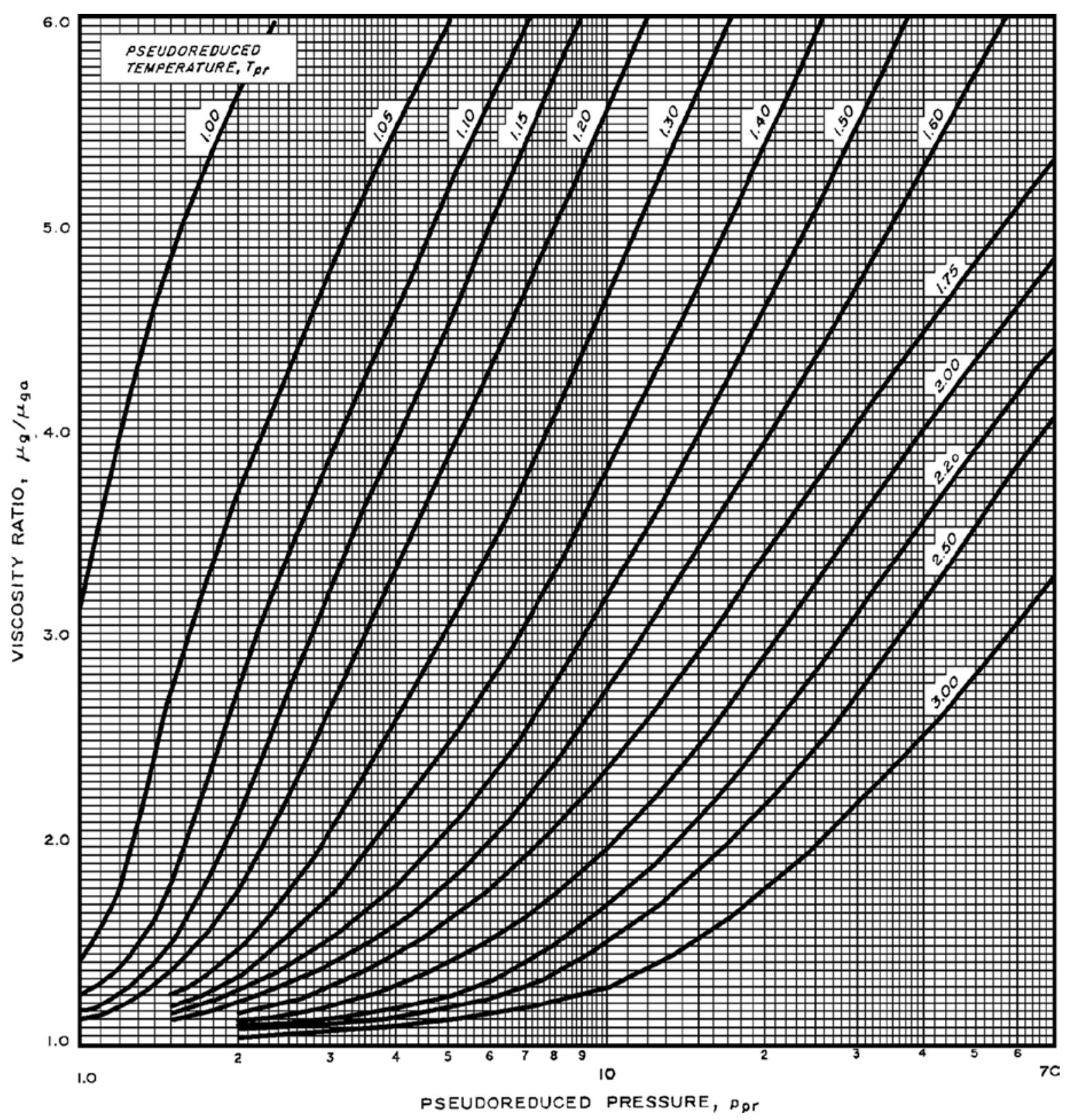

Figure 27 - Viscosity Ratio Chart 